Portland State University

PDXScholar

\title{
Investigating Environmental Migration and Other Rural Drought Adaptation Strategies in Baja California Sur, Mexico
}

\author{
Melissa Haeffner \\ Portland State University, melh32@pdx.edu \\ Jacopo A. Baggio \\ Utah State University \\ Kathleen Galvin \\ Colorado State University - Fort Collins
}

Follow this and additional works at: https://pdxscholar.library.pdx.edu/esm_fac

Part of the Environmental Health and Protection Commons, and the Environmental Indicators and Impact Assessment Commons

\section{Let us know how access to this document benefits you.}

\section{Citation Details}

Haeffner, Melissa; Baggio, Jacopo A.; and Galvin, Kathleen, "Investigating Environmental Migration and Other Rural Drought Adaptation Strategies in Baja California Sur, Mexico" (2018). Environmental Science and Management Faculty Publications and Presentations. 242.

https://pdxscholar.library.pdx.edu/esm_fac/242

This Post-Print is brought to you for free and open access. It has been accepted for inclusion in Environmental Science and Management Faculty Publications and Presentations by an authorized administrator of PDXScholar. Please contact us if we can make this document more accessible: pdxscholar@pdx.edu. 
A Qualitative Comparative Analysis (QCA) investigating environmental migration and other rural drought adaptation strategies in Baja California Sur, Mexico

\section{Introduction}

2

Droughts have increased in frequency, intensity, duration, and magnitude in Mexico and (Cavazos and Arriaga-Ramírez 2012, Mendoza and Velasco, 2005). While the biophysical and ecological impacts of droughts are well-known, what is less understood is how rural households are likely to respond to drought based on their access and dependence on specific social, economic, and biophysical resources. Extended droughts can negatively impact rural small land holders by reducing stream flows, well levels, and irrigation availability, leaving them to draw on stored water that cannot be easily replenished.

Rural households can respond to drought by employing short-term coping mechanisms (Ellis 2000), and/or longer term adaptation strategies (Kelly and Adger 2000). For example, changing farm practices or finding off-farm work have been shown to be important survival mechanisms, among smallholder farmers in southeastern Mexico (Mardero 2015). Change in farming practices can include corralling animals as range forage yields decline, trading or selling water-intensive cows for more drought-tolerant goats, and planting fodder when alfalfa prices skyrocket (Agrawal, 2010). Families might also change their livelihoods through an occupational change such as acquiring temporary work through government programs or obtain other off-farm work (Liverman 1999). Households may also adopt more "drastic" strategies to cope/adapt to drought, for example, by moving the entire household or single household members away from the environmental threat (Afifi et al. 2013; Gray and Mueller 2012; Leighton 2011; McLeman and Ploeger 2012). Environmental migration can be thought of as the voluntary movement of people related to a change in weather or climate. With respect to Mexico, the findings on the relationship between drought and migration have been ambiguous. Riosmena et al. (2013) found that migration was correlated with drought in the dry, northern states of Mexico but not in the wet, southern states. Meanwhile, Kniveton (2008) found that migration decreased with lower rainfall in two states of Mexico. Using data sources of Mexican migrants in the US labor force, Pugatch and Yang (2011) found that reductions in rainfall were correlated with increased migration rates out of Mexico. Chort (2014) found that increased rainfall was correlated with migration only for those that already had the intention to move. The conflicting evidence leaves open questions about the relationship between environmental conditions, specific household characteristics (or traits), and the adoption of response strategies.

Rural households use, manage, and exchange their resources to achieve specific response and adaptation strategies during droughts. Previous studies have highlighted specific household characteristics commonly associated with decision-making: financial diversity (De Janvry and Sadoulet 2001), the amount and type of land 


\section{A Qualitative Comparative Analysis (QCA) investigating environmental migration and other rural drought adaptation strategies in Baja California Sur, Mexico}

1 and livestock owned (Massey et al. 2010), membership in social organizations (a mechanism to draw on social

2 capital and social networks for help) (Narayan and Pritchett 1999), female education (Blankespoor et al. 2010), and

3 access to fresh water sources (Gray 2009). First, maintaining multiple income streams (financial diversity) helps

4 households manage water resource-related fluctuations like farm production shocks (Eakin 2005, Ellis 200, Nelson

5 et al. 2005, Vilei and Dabbert 2007). Second, livestock are central and can be used as assets to sell or trade in

6 drought times (Massey et al. 2010, Nelson et al. 2005). Third, land is required to raise livestock, and tenure has long

7 been considered an important aspect of vulnerability under various ownership options and land reform in Mexico

8 (Liverman, 1990). Fourth, the ability to use social networks is often found as a key predictor in relation to how

9 households make migration decisions (Narayan and Pritchett 1999). Social networks that are maintained through

10 social bonds, sharing, and cooperation between households, and transferring remittances have been shown to have

11 varying impact on decisions to migrate or not and to the ability of community to be robust to both social and

12 ecological changes (author et al. 2016a). Fifth, education - independent of income - has often been found to

13 positively contribute to the greater capacity of the household to respond to drought and other extreme events (Eakin

14 2005; Gray 2009; Laczko and Aghazarm 2009; Massey et al. 2010; Romero Lankao and Qin 2011). The education

15 of women, in particular, with literacy and associated higher employment levels, have long been argued as the best

16 predictors of child survival, fertility rate reduction, and increased agency (Sen, 1999). More recently, the number of

17 educated girls and women in a household has been associated with reduced negative effects of drought (Blankespoor

18 et al. 2010) due to a higher capacity to use and exchange resources in times of needs (Wamsler 2011). Sixth, a

19 household's ability to directly access fresh water for human consumption gives a family agency in managing their

20 water storage, consumption, and conservation in times of scarcity (Gray 2009). In addition to these six household

21 "resources," households may exhibit other traits that influence their decisions to adopt or not to specific drought

22 adaptation strategies (e.g. climate sensitivity, location of households and occupation of head of household). For

23 example, environmental migration studies place emphasis on whether or not the household perceives weather

24 change (climate sensitivity) as a factor in peoples' decisions to respond to environmental change or degradation

25 (Gray 2009; Laczko and Aghazarm 2009; Saldaña-Zorrilla 2008; Vilei and Dabbert 2007). While these variables

26 have been proposed as important for drought adaptation, how these variables interact with each other remains

27 unclear. Household traits are interconnected, and it is likely their combination that drives behavior. Due to this 


\section{A Qualitative Comparative Analysis (QCA) investigating environmental migration and other rural drought adaptation strategies in Baja California Sur, Mexico}

complexity, there have been calls for new socio-ecological methods to analyze how global environmental change

2 interferes with livelihoods (for example, Kok, et al., 2016).

In this paper, we examine if certain configurations of household traits shape rural decision-making in

response to drought in two sites in Baja California, Mexico. Based on the preceding, we expected that rural households experiencing drought in Baja California Sur, Mexico responded to drought in different ways, and the ways they chose to respond were based not on just one factor alone, but on the interactions of their access to financial diversity, land and livestock ownership, membership in social organizations, higher levels of education among the women in the household, and access to fresh water sources.

Whether the head of household engages in ranching as the primary occupation are considered important in the context of Baja California in Mexico. Rural households in Baja California Sur often self-identify as rancheros sudcalifornianos, or, simply, rancheros (Cariño, et al., 2012). They derive their namesake from their traditional livelihood practice of ranching. However, as the climate and society have changed, the ability to maintain ranching as an economically sustainable livelihood has been threatened. Called the "original cowboys," rancheros are known to have been highly mobile in the past, raising cattle in the mountains during rainy years and moving to a beach house to fish during droughts (personal communication MH, 2013).

To better understand how contemporary rancheros respond to drought, we looked at four specific adaptation strategies: 1) environmental migration (direct), 2) household member migration (indirect), 3) changing farm practices and 4) finding off-farm work. We assess whether specific household traits (characteristics) are indicative of adoption of specific drought adaptation strategies via visualization and retain complexity through qualitative comparative analysis. Lastly, we contextualize the importance of specific traits that are most related to specific strategy adoption decisions that may inform local drought and water conservation policy and practice. While some households maintain two properties, rising real estate prices encourages contemporary rancheros to sell their property, limiting their ability to move to access different grazing lands during later droughts (personal communication MH, 2013). Little is published about what sorts of resources rancheros currently have access to or how rancheros are adapting to more severe droughts. Since these rancheros occupy key water recharge zones for aquifers supplying urban centers, water managers are increasingly interested in the activities of these rancheros and their implications for watershed systems (Niparajá 2014). If rancheros become more sedentary, their activities in the watershed will have a greater impact on the sustainability of the watershed. If rancheros are able to continue 
ranching, then they will have a greater ability to be involved in water and soil conservation. Therefore, the study

2 provides insights into household trait configurations that facilitate or hinder drought adaptation strategies which can

3 inform government agencies and non-governmental organizations working with ranchero groups.

4

5

6 Methods

$7 \quad$ Study area

\section{A Qualitative Comparative Analysis (QCA) investigating environmental migration and other rural drought adaptation strategies in Baja California Sur, Mexico}

(1)

8 Beginning in 2006, the northern states of Mexico registered significant drops in precipitation that peaked in 2011-2012, considered the worst drought to hit Mexico in seventy years (CONAGUA 2013). During this drought, Baja California Sur recorded the most serious decrease in rainfall, by 70\% (CONAGUA 2013). The study area is located in the southern half of Mexico's Baja peninsula, in the state of Baja California Sur. Mexico declared a federal drought emergency in three municipalities in 2011 where rural rancheros live (CONAGUA 2013) - two of which are studied here (Figure 1).

4

Fig. 1 Map showing the two ranching community locations surveyed for this study (shaded)

\section{Ranchero survey}

The household survey we developed was targeted to rural households exposed to a severe drought from 2006-2012 (see Online Resources for the full survey in English and Spanish). The survey was built on empirical studies focusing on the relationship between household characteristics and drought coping/adaptation response strategies.

First, Web of Science, Science Direct, JSTOR, and EBSCOHost were searched by using the following keywords: "adaptive capacity index," "adaptive capacity assessment," "drought adaptation," and "environmental migration.” A total of thirteen peer-reviewed journal articles were used to select indicators for the household survey (Alscher 2010; de Janvry and Sadoulet 2001; Eakin 2005; Ellis 2000; Gray 2009; Laczko and Aghazarm 2009;

26 Liverman 1999; Massey et al. 2010; Narayan and Pritchett 1999; Nelson et al. 2005; Saldaña-Zorrilla 2008; Vilei

27 and Dabbert 2007; Vincent and Cull 2010). From these published studies, we chose questions to assess the six 8 household traits considered to be key factor in household decision-making: financial diversity, owning livestock, 
A Qualitative Comparative Analysis (QCA) investigating environmental migration and other rural drought adaptation strategies in Baja California Sur, Mexico

1 owning land, social networks, female education, and access to fresh water sources. Because we wanted to know if

2 there was a connection between ranchero perception of the weather and their drought response, we also elicited

3 climate sensitivity, by asking if the respondent perceived changes in the weather. Finally, we asked whether the

4 heads of household ranched as their main livelihood and household location. Finally, local experts reviewed the

5 survey to assess the cultural appropriateness and wording of the identified survey questions. Once accepted, we

6 piloted the survey with two ranchero households within the two municipalities of choice. Table 1 reports the symbol,

7 meaning, and descriptions of the variables used in this study. 
A Qualitative Comparative Analysis (QCA) investigating environmental migration and other rural drought adaptation strategies in Baja California Sur, Mexico

2 Table 1. Household traits and drought coping/adaptation strategies

\section{Household traits}

$\begin{array}{ll}\begin{array}{ll}\text { Symbol } \\ \text { reg }\end{array} & \begin{array}{l}\text { ID } \\ \text { edu }\end{array} \\ \text { rch } & \text { Fegion } \\ \text { wat } & \begin{array}{l}\text { Head of the household } \\ \text { occupation } \\ \text { Access to surface water for } \\ \text { human consumption }\end{array} \\ \text { clm } & \text { Climate sensitivity } \\ \text { soc } & \text { Social capital } \\ \text { fin } & \text { Financial diversity } \\ \text { tit } & \text { Land ownership } \\ \text { lvs } & \text { Livestock ownership }\end{array}$

\section{Adoption Strategies}

Symbol ID

Adoption of any drought strategy

Environmental migration

Any household member migration

Change in farm practices

Acquired off-farm work
Presence/absence of any drought strategy

Presence/absence of environmental migration in response to drought Presence/absence of any household member migration during drought years 2006-2012 Presence/absence of changing farm practices to respond to drought

Presence/absence of changing livelihood to respond to drought

\section{Description}

The household lived in the Loreto municipality (0) or the La Paz municipality (1).

Any female in the household reporting any secondary or higher schooling.

Head of household reporting "rancher" as their occupation.

The household reported accessing surface water for human consumption.

The respondent responded positively to the question "Have you perceived that the weather has been unpredictable in the last ten years?"

The respondent responded positively to the question "Are you a member of a community organization?"

The household reported more than one source of income including business income, remittances, government aid, pensions.

Household reported that they held a title to their land.

Household reported that they own any type of farm animals including chickens, cows, mules, horses or goats.

\section{Description}

In response to the question, "During the last drought, did you take any of the following actions to mitigate the negative effects?," respondent marked one or more option from the list or wrote in an answer.

In response to the question, "During the last drought, did you take any of the following actions to mitigate the negative effects?," respondent marked the option "migrate" (migrar).

For each household member, respondent was asked if they had migrated, and if so, the years. Household members who migrated during the drought years (2006-2012) were considered in this group.

In response to the question, "During the last drought, did you take any of the following actions to mitigate the negative effects?" respondent marked one or more of the following: corralled their animals, traded cows for goats, planted fodder. In response to the question, "During the last drought, did you take any of the following actions to mitigate the negative effects?" respondent marked one or more of the following: obtained temporary work, obtained outside work. 


\section{A Qualitative Comparative Analysis (QCA) investigating environmental migration and other rural drought adaptation strategies in Baja California Sur, Mexico}

Data were collected between July and August 2013, during the dry season immediately following a severe drought (see Online Resources and explanation of sampling method). Respondents were given a list of activities and asked which, if any, they performed in response to the last drought (2006-2012) (see Online Resources for the precise survey questions asked). Between the different potential activities, we classified as drought coping/adaptation strategies the following: 1) environmental migration, 2) migration even if not perceived as a direct consequence of drought, 3) change in farming practices (i.e., corralled their animals, traded cows for goats, planted fodder), and 4) occupational/livelihood changes (i.e., temporary work through the government program, obtained other outside work). We include the measure of "any household member migration" to account for cases in which drought was not directly declared as the main driver of migration by the respondents but potentially could have been a contributing factor to the migration decision (e.g. due to indirect economic impact).

In addition to surveys, eleven ranchero groups (some individual, some groups of neighbors) were selected for one-hour, in-depth interviews on their drought experiences in Baja California Sur (see Online Resources part 2). Illustrative remarks are included to provide deeper meaning to the results.

Analysis

The relationship between household traits and strategies is assessed via two main methods: visualization of traits' co-occurrence in relation to the adoption of specific strategies, and assessing configurations of traits that lead to specific strategies via qualitative comparative analysis (QCA). We complement the description with insight from the in-depth interviews. The analysis combines visualization and qualitative methods to better identify complex decision-making patterns in relation to the adoption of specific strategies in response to drought.

For both visualization and QCA, we assess presence and absence of a specific trait and adoption (or not) of a specific strategy (see Table 1). Visualization of trait co-occurrence highlights which traits are more likely to cooccur in the presence (or absence) of a specific strategy. Following a similar approach, (author et al. 2016b) analyzed the co-occurrence of institutional design principles and their relationship to successful common pool resource regimes, while Rocha et al. (2015) analyzed co-occurrence of drivers in marine regime shifts. This type of analysis is purely visual and can be thought of as a first step in identifying the relationship between trait configurations and strategies. To gain a deeper knowledge of the trait configuration - drought response relationship we complement the co-occurrence analysis with QCA (as in author et al. 2016b). 
A Qualitative Comparative Analysis (QCA) investigating environmental migration and other rural drought adaptation strategies in Baja California Sur, Mexico

\section{Results}

Rancheros' perceptions and drought strategies

QCA allows for the pairwise comparison of cases. Using Boolean algebra, QCA lists all possible combinations of relevant conditions that lead to a certain outcome. Here, we assess the relationship between household traits (specific configurations) and adoption or non-adoption of a specific strategy (outcome) (Ragin 1987, Ragin 2014). In other words, QCA allows the establishment of necessary and sufficient conditions for an outcome to occur. A trait (or configuration of traits) is necessary if it must be present for a certain outcome to occur. A trait (or configuration of traits) is sufficient if, by itself, it can produce a certain outcome (Ragin 1987). A trait (or configuration of traits) is both necessary and sufficient if it is the only cause to the outcome (see Online Resource for more information). QCA also allows us to assess the consistency, or the degree to which a relation of necessity or sufficiency is met in a given dataset, and coverage that provides a "degree" of relevance of the sufficiency and necessity conditions for an outcome to occur. Both metrics vary between 0 and 1 , where 0 indicates no consistency or coverage, and 1 indicates complete consistency/coverage.

We employ QCA to understand the multiple, different, and non-exclusive trait configurations of rural households that lead to the adoption of different strategies. We focus on specific household traits leading to (if any) the drought strategies identified, and not on the linear relation between variables. We also pay close attention to the sensitivity of QCA to missing information. Following author et al. (2016b), QCA is complemented by a reliability metric based on missing value imputation. The metric proposed in author et al. (2016b) allows us to build a range of reliability for the information presented.

Although QCA cannot be used to make cause-effect inferences, such as whether certain household traits lead to specific drought strategies or vice versa, it helps us discover which traits combine to be sufficient and/or necessary for household to adopt specific drought strategies.

Finally, we complement the results of the visualization and QCA with in-depth interviews to assess the validity of our findings and to check whether there are other subtler key components of the household decisionmaking process in relation to drought strategy adoption in the surveyed communities. The integration of cooccurrence and QCA with in-depth interviews and knowledge of the system allows researchers to increase the reliability of the results (author et al. 2016b, Barnett et al. 2016). 
A Qualitative Comparative Analysis (QCA) investigating environmental migration and other rural drought adaptation strategies in Baja California Sur, Mexico

Of the 163 rancheros interviewed, the majority (86\%) reported that they responded to the 2006-2012 drought in some way while $14 \%$ reported that they did nothing (see Table 2). Among the strategies analyzed, changing farming practices and acquiring off-farm work were much more prevalent than either type of migration ( $>50 \%$ vs. $<30 \%$ respectively).

Table 2. Self-reported drought strategies for the 163 households surveyed

\begin{tabular}{l|rr}
\hline Strategy (not mutually exclusive) & No (\%) & Yes (\%) \\
\hline Any strategy & $22(14 \%)$ & $139(86 \%)$ \\
Changed farm practices & $72(44 \%)$ & $90(56 \%)$ \\
Acquired off-farm work & $68(42 \%)$ & $93(58 \%)$ \\
Environmental migration & $137(85 \%)$ & $24(15 \%)$ \\
Household member migration during drought years & $115(71 \%)$ & $47(29 \%)$ \\
Farm + Off-farm & $104(65 \%)$ & $57(35 \%)$ \\
Farm + Environmental migration & $141(88 \%)$ & $20(12 \%)$ \\
Off-farm + Environmental migration & $141(88 \%)$ & $20(12 \%)$ \\
Farm + Off-farm + Environmental migration & $158(98 \%)$ & $3(2 \%)$ \\
\hline \hline
\end{tabular}

Table 3 summarizes the data regarding the presence or absence of the household traits when they adopt

9 always present in the case of households deciding to adopt a strategy. Owning livestock characterizes 100\% of

10 households choosing environmental migration, $89 \%$ of households with any member migration, $97 \%$ of households

11 deciding to change farm practices, and $93 \%$ of households that acquired off-farm work. Meanwhile, climate

12 sensitivity characterized $92 \%$ of households choosing environmental migration, $89 \%$ of households choosing

13 migration, $87 \%$ of households that decided to change farming practices, and $88 \%$ of households that acquired off-

14 farm work. On the other hand, relying on surface water (wat) and ranching as the primary livelihood (rch) are traits

15 mostly absent in households deciding to adopt a drought strategy. From this simple table, we are tempted to

16 conclude that owning livestock and climate sensitivity are key traits for households adopting drought strategies

17 while accessing surface water and having a rancher head of household are inconsequential. However, traits analyzed

18 in isolation can lead to misinterpretation. It is important to look at the household profile mix, or co-occurrence, to

19 assess what type of trait configurations characterize households deciding to adopt specific strategies. Households are

20 complex, and household decision-making is complex -they cannot be reduced to single variables, but co-occur in

21 meaningful ways. 
A Qualitative Comparative Analysis (QCA) investigating environmental migration and other rural drought adaptation strategies in Baja California Sur, Mexico 
A Qualitative Comparative Analysis (QCA) investigating environmental migration and other rural drought adaptation strategies in Baja California Sur, Mexico

1 Table 3. Household traits presence and absence for total sample and when adopting specific drought strategies

\begin{tabular}{|c|c|c|c|c|c|c|c|}
\hline $\begin{array}{l}\text { Household Traits } \\
\text { (symbols in } \\
\text { parenthesis) }\end{array}$ & Values & $\begin{array}{c}\text { Total } \\
\text { Sample } \\
\mathrm{n}=163\end{array}$ & $\begin{array}{c}\text { Any } \\
\text { Strategy } \\
\mathrm{n}=139\end{array}$ & $\begin{array}{c}\text { Environmental } \\
\text { Migration } \\
\mathrm{n}=24\end{array}$ & $\begin{array}{c}\text { Household } \\
\text { Migration } \\
\mathrm{n}=47\end{array}$ & $\begin{array}{c}\text { Changed } \\
\text { Farming } \\
\text { Practices } \\
\mathrm{n}=90\end{array}$ & $\begin{array}{c}\text { Acquired } \\
\text { Off- } \\
\text { Farm Work } \\
n=93\end{array}$ \\
\hline \multirow{3}{*}{$\begin{array}{l}\text { Lives in the region } \\
\text { that has better } \\
\text { urban access (reg) }\end{array}$} & Absence & $42(26 \%)$ & $40(29 \%)$ & $11(46 \%)$ & $22(47 \%)$ & $39(43 \%)$ & $33(36 \%)$ \\
\hline & Presence & $120(74 \%)$ & $98(71 \%)$ & $13(54 \%)$ & $25(53 \%)$ & $50(56 \%)$ & $59(63 \%)$ \\
\hline & Missing & $1(1 \%)$ & $1(1 \%)$ & $0(0 \%)$ & $0(0 \%)$ & $1(1 \%)$ & $1(1 \%)$ \\
\hline \multirow{3}{*}{$\begin{array}{l}\text { Any female } \\
\text { household member } \\
\text { graduated from } \\
\text { primary school } \\
\text { (edu) }\end{array}$} & Absence & $78(48 \%)$ & $66(48 \%)$ & $9(38 \%)$ & $14(30 \%)$ & $37(41 \%)$ & $45(48 \%)$ \\
\hline & Presence & $82(51 \%)$ & $71(51 \%)$ & $15(63 \%)$ & $33(70 \%)$ & $52(58 \%)$ & $47(51 \%)$ \\
\hline & Missing & $3(2 \%)$ & $2(1 \%)$ & $0(0 \%)$ & $0 \quad(0 \%)$ & $1(\%)$ & $1(1 \%)$ \\
\hline \multirow{3}{*}{$\begin{array}{l}\text { Head of household } \\
\text { is a rancher (rch) }\end{array}$} & Absence & $125(76 \%)$ & $106(76 \%)$ & $17(71 \%)$ & $37(79 \%)$ & $66(73 \%)$ & $72(77 \%)$ \\
\hline & Presence & $38(24 \%)$ & $33(24 \%)$ & $7(29 \%)$ & $10(21 \%)$ & $24(27 \%)$ & $21(23 \%)$ \\
\hline & Missing & $0 \quad(0 \%)$ & $0 \quad(0 \%)$ & $0(0 \%)$ & $0(0 \%)$ & $0 \quad(0 \%)$ & $0 \quad(0 \%)$ \\
\hline \multirow{3}{*}{$\begin{array}{l}\text { Relies on surface } \\
\text { water for human } \\
\text { consumption (wat) }\end{array}$} & Absence & $136(83 \%)$ & $115(83 \%)$ & $20(83 \%)$ & $37(79 \%)$ & $74(82 \%)$ & $75(81 \%)$ \\
\hline & Presence & $27(17 \%)$ & $24(17 \%)$ & $4(17 \%)$ & $10(21 \%)$ & $16(18 \%)$ & $18(19 \%)$ \\
\hline & Missing & $0 \quad(0 \%)$ & $0 \quad(0 \%)$ & $0 \quad(0 \%)$ & $0 \quad(0 \%)$ & $0 \quad(0 \%)$ & $0 \quad(0 \%)$ \\
\hline \multirow{3}{*}{$\begin{array}{l}\text { Reports } \\
\text { unpredictable } \\
\text { weather in the last } \\
10 \text { years }(\mathrm{clm}) \\
\end{array}$} & Absence & $13(8 \%)$ & $12(9 \%)$ & $2(8 \%)$ & $5(11 \%)$ & $10(11 \%)$ & $9(10 \%)$ \\
\hline & Presence & $148(91 \%)$ & $125(90 \%)$ & $22(92 \%)$ & $42(89 \%)$ & $78(87 \%)$ & $82(88 \%)$ \\
\hline & Missing & $2(1 \%)$ & $2(1 \%)$ & $0 \quad(0 \%)$ & $0 \quad(0 \%)$ & $2 \quad(2 \%)$ & $2(2 \%)$ \\
\hline \multirow{3}{*}{$\begin{array}{l}\text { Belongs to an } \\
\text { organization (soc) }\end{array}$} & Absence & $78(48 \%)$ & $69(50 \%)$ & $12(50 \%)$ & $18(38 \%)$ & $43(48 \%)$ & $47(51 \%)$ \\
\hline & Presence & $82(50 \%)$ & $67(48 \%)$ & $12(50 \%)$ & $27(57 \%)$ & $45(50 \%)$ & $45(48 \%)$ \\
\hline & Missing & $3 \quad(2 \%)$ & $3(2 \%)$ & $0 \quad(0 \%)$ & $2 \quad(4 \%)$ & $2 \quad(2 \%)$ & $1 \quad(1 \%)$ \\
\hline \multirow{3}{*}{$\begin{array}{l}\text { Reports more than } \\
\text { one income stream } \\
\text { (fin) }\end{array}$} & Absence & $58(36 \%)$ & $44(32 \%)$ & $8(33 \%)$ & $15(32 \%)$ & $23(26 \%)$ & $35(38 \%)$ \\
\hline & Presence & $104(4 \%)$ & $94(68 \%)$ & $16(67 \%)$ & $31(66 \%)$ & $66(73 \%)$ & $58(62 \%)$ \\
\hline & Missing & $1 \quad(1 \%)$ & $1 \quad(1 \%)$ & $0 \quad(0 \%)$ & $1 \quad(2 \%)$ & $1 \quad(1 \%)$ & $0 \quad(0 \%)$ \\
\hline \multirow{3}{*}{$\begin{array}{l}\text { Holds land title } \\
\text { (tit) }\end{array}$} & Absence & $59(36 \%)$ & $47(34 \%)$ & $7(29 \%)$ & $16(34 \%)$ & $32(36 \%)$ & $31(33 \%)$ \\
\hline & Presence & $99(61 \%)$ & $87(63 \%)$ & $17(71 \%)$ & $30(64 \%)$ & $56(62 \%)$ & $58(62 \%)$ \\
\hline & Missing & $5 \quad(3 \%)$ & $5 \quad(4 \%)$ & $0 \quad(0 \%)$ & $1 \quad(2 \%)$ & $2(2 \%)$ & $4 \quad(4 \%)$ \\
\hline \multirow{3}{*}{$\begin{array}{l}\text { Owns livestock } \\
\text { (lvs) }\end{array}$} & Absence & $13(8 \%)$ & $7 \quad(5 \%)$ & $0 \quad(0 \%)$ & $3(6 \%)$ & $0 \quad(0 \%)$ & $5(5 \%)$ \\
\hline & Presence & $147(90 \%)$ & $129(93 \%)$ & $24(100 \%)$ & $42(89 \%)$ & $87(97 \%)$ & $86(92 \%)$ \\
\hline & Missing & $3(2 \%)$ & $3(2 \%)$ & $0 \quad(0 \%)$ & $2(4 \%)$ & $3 \quad(3 \%)$ & $2(2 \%)$ \\
\hline
\end{tabular}

*Note: Totals may not sum to $100 \%$ because of rounding in the percentage calculations. Total sample represents presence/absence of specific traits independent on adoption (or non-adoption) of specific drought strategies.

\section{Trait Co-Occurrence}

We start our analysis of trait combinations by identifying co-occurrence of household traits under different

9 coping/adaptation strategies. Here we present only results for complete cases (see Online Resources for co-

10 occurrence patterns using missing value imputation). 


\section{A Qualitative Comparative Analysis (QCA) investigating environmental migration and other rural drought adaptation strategies in Baja California Sur, Mexico}

Generally, households which did not adopt a drought strategy show a lower level of trait co-occurrence as can be seen by the lighter colors representing lower percentages in Figure 2a. Households that responded to drought, independent of the specific type of strategy, are characterized by the co-occurrence of financial diversity (fin), climate sensitivity (clm), and land title (tit) (see Figure 2b). Other traits such as region (reg) and climate sensitivity (clm) co-occur independently in whether households adopted a strategy or not. Households who reported strategy adoption tended to have both livestock (lvs) and a land title (tit) assets, as opposed to those who did not, and this was true of all types of strategy adoption except for acquiring off-farm work for which these traits co-occurred equally.

\section{Environmental migration}

Fifteen percent of our sample self-reported migration as a direct drought strategy. The main discriminant of household traits between those who adopted environmental migration as a strategy and those who did not is the cooccurrence of female education (edu), owning livestock (lvs), and climate sensitivity (clm) (see Figure 2c vs. 2d), which is stronger in households who reported environmental migration. Holding a land title (tit) and having multiple sources of income (fin) co-occurred for both groups, but this co-occurrence was slightly stronger for households that adopted environmental migration (Figure 2d). Finally, living in La Paz (reg), having livestock (lvs) and climate sensitivity (clm) co-occur in a household that did not migrate directly for environmental reasons.

\section{Household member migration}

Migration can potentially be an indirect or partial effect of environmental condition, especially if drought

influences household economic outcomes. Twenty-nine percent of households surveyed had a member who migrated during the drought years 2006-2012, whether or not they attributed this movement to the drought. Figure $2 \mathrm{e}$ and $2 \mathrm{f}$ show household trait co-occurrence in relation to household member migration. Households where migration occurred are characterized by higher co-occurrence of female education (edu) with climate sensitivity (clm) and co-occurrence between increased social capital (soc) and owning livestock (lvs) as opposed to households where no migration occurred (see Figure 2e and 2f). As for adopting environmental migration, migration strategies are not chosen by household in which climate sensitivity (clm), owning livestock (lvs) and living in La Paz cooccur. Households where no members migrated during the drought years are characterized by higher co-occurrence of living in the La Paz municipality, being climate sensitive, and owning livestock. 
A Qualitative Comparative Analysis (QCA) investigating environmental migration and other rural drought adaptation strategies in Baja California Sur, Mexico

\section{Farming practices}

More than half of the households (56\%) reported changing farming practices as a drought strategy. Living

in the La Paz municipality (reg) and holding a land title (tit) were more likely to co-occur in households that did not change their farm practices. The traits that most likely discriminate between the households who changed their farming practices and households that did not are: financial diversity (fin), owning a title to the land (tit), and owning livestock (lvs), accompanied by the co-occurrence of female education (edu) and livestock ownership (lvs) (see Figure $2 \mathrm{~g}$ vs. 2h).

\section{Off-farm work}

Acquiring off-farm work was the most adopted strategy, although marginally (57\% vs. 56\% that adopted changing farming practices). However, there is no clear trait distinction between the co-occurrence patterns of households that decided to acquire off-farm work vs. households that did not acquire off-farm work (see Figure $2 \mathrm{i}$ and $2 \mathrm{j})$.

Fig. 1 Frequency household traits of co-occurrence by type of strategy. Abbreviations listed in Table 1. Color online.

\section{Qualitative Comparative Analysis (QCA)}

28 Co-occurrence patterns hint to potential differences in the relationship between household traits and 29 adoption of specific drought strategies. We employ QCA to assess whether and which specific traits and/or trait 30 configurations were related to the adoption (or non-adoption) of drought strategies (see Online Resources for details 31 and 'truth tables,' all possible configurations). Figure 3 reports results of the relative importance of specific traits. 
A Qualitative Comparative Analysis (QCA) investigating environmental migration and other rural drought adaptation strategies in Baja California Sur, Mexico

1 Trait position is given by their frequency in QCA solution sets leading to adoption and non-adoption of specific

2 drought strategies (see Online Resources Table 3). We only took into account solution sets with consistency $>0.5$,

3 in which the configurations occur in over $50 \%$ of cases. Trait position in Figure 3 relates to the ability of single traits

4 to facilitate or hinder specific strategies where those which appear in the top left quadrant facilitate strategy adoption

5 while those that appear in the bottom right quadrant hinder adoption of that strategy.

Fig. 2 Facilitating (top left quadrants), hindering (bottom right quadrants) household traits for each drought strategy for complete cases, imputation of missing value to 0 (absence of trait) and imputation to missing values to 1 (presence of trait).

\section{Qualitative integration}

To assess our results, we triangulate the findings of the co-occurrence analysis and QCA with in-depth interviews with rancheros (see Online Resources for details). In line with the descriptive statistics showing that $90 \%$ 


\section{A Qualitative Comparative Analysis (QCA) investigating environmental migration and other rural drought adaptation strategies in Baja California Sur, Mexico}

1 of the respondents were aware of the weather becoming more unpredictable in the last ten years, the interviews also

2 demonstrated that rancheros were very aware of how environmental conditions impact their livelihoods. Some

3 respondents told us that they chose land based on their local system knowledge, specifically in relation to weather

4 patterns. For example, one respondent's commented: "Because we had some relatives in the ejido, ${ }^{1}$ and it rains more

5 here, there was more grass and water. There's more life here, so to speak." Further, water availability was often

6 viewed in terms of time rather than quantity. Given the limitations of storage capacity in the region, when water is

7 available is just as or even more important as how much, as summarized by another respondent: "We had a single

8 day to provide water for the animals with the little water that was left in the well. We did this every three to four

9 days. We do not have any [storage for water]." Further, drought is a clear issue in the region, as another ranchero

10 noted: "I am struggling. We struggle and suffer. There are two or three goats left to support me out of thirty or forty.

11 And you can see that in most ranches, you can see the lack of animals, there are no animals, there is nothing." And

12 more: "We are saving some of the animals. Otherwise, we have to invest money in them, getting them food. Now

13 we are selling the livestock and using the money to buy food. The drought is pretty serious." Owning livestock

14 seemed to be a key factor in assessing drought impacts which was also strongly emphasized in the QCA. The

15 importance of owning livestock is thus reiterated as a key trait in determining which and if household adopts

16 drought response strategies.

17 One puzzling result from the QCA described above was that living in a region with relatively better urban

18 access hindered certain drought strategy adoptions, namely changing farm practices and finding off-farm work. On

19 the one hand, Table 2 shows that the majority of households living in La Paz adopted drought strategies, and they

20 did so through changing farm practices and acquiring off-farm work. On the other hand, what we also found was

21 that $18 \%$ of the La Paz households did not adopt a drought strategy at all, compared to only one household (5\%) in

22 the Loreto municipality. Turning to the qualitative data, we can start to understand why we might see this

23 phenomenon. According to the interviews, living near a more urban area (the La Paz municipality) allowed some

24 households to access municipal water. It is easier to access the urban center by better-maintained roads, and these

25 households tended to talk about how they used their urban proximity to access water during droughts. This ranchero 26 said: "When they brought water from La Paz, we had to transport it in a car." It was also the case that some houses

\footnotetext{
${ }^{1}$ A system of cooperative land tenure.
} 


\section{A Qualitative Comparative Analysis (QCA) investigating environmental migration and other rural drought adaptation strategies in Baja California Sur, Mexico}

we visited in this region also had indoor plumbing for faucets and even toilets, though rare (as opposed to no houses

2 with running water we visited in the Loreto municipality). Indeed, of the 27 households who relied on surface water

3 for human consumption, only three did not respond to the drought. On the flip side, when conducting the survey in

4 the La Paz municipality, we found that the houses near the main highway were able to access the relatively more

5 reliable urban pipe system (a tandeo system in which water is available every other day), and 21 of these households

6 regularly used urban water for their animals. For these La Paz households, potable water is not scarce or reserved

7 only for human consumption (at least not during non-drought times). La Paz households seemed to have been under

8 less pressure to adopt drought strategies because they were able to access water elsewhere. This system is certainly

9 more convenient than collecting water or the gravity-fed irrigation system available in the Loreto municipality.

10 Access to safe and clean water is a sustainable development goal, and the fact that La Paz rancheros can access

11 potable water is a success. Yet, households who are driving to the city are exchanging one asset (money for gas) for

12 another (water).We want to be careful in recognizing the potential for unintended consequences such as the radical

13 change this has on ranchero traditions, and it seems, to any kind of sustainable practices.

14 The analysis above also indicates that environmental migration was the least popular strategy to respond to

15 the drought. However, the qualitative data collected in the interviews showed that temporary migration is also an

16 important part of the ranchero story, which might be why we saw a higher percentage of households who had a

17 household member who migrated during the drought years but did not relate it directly to the drought. Tellingly, a

18 popular response to how long household members left the household (beyond just the drought years) was "va y

19 viene," (used in more than 66 write-in responses) translated to "come and go." This response was common whether

20 the respondent moved between rural areas or to urban areas, suggesting that temporary migration is an important

21 part of the ranchero life. When our interviewees did talk about migrating due to water scarcity, they talked about it

22 in tandem with other driving factors, like finding economic alternatives. According to one respondent, migration

23 may be due to drought, even if not directly related to it: "They have left because there are no jobs here, no jobs at all.

24 Because there are not any jobs here that pay very much. It used to rain a lot; there was water. These relatives had a

25 lot of livestock; they made cheese, they herded the animals... [I don't sell animals] Not anymore. Too little

26 livestock." Longitudinal household studies would also be needed to capture more direct measures of behavior

27 before, during, and after climatological events. Additionally, we collected data in rural settings when much of the

28 migration literature focuses on rural-to-urban migration (for example, Qin, 2010). Rural-rural seasonal migration 
A Qualitative Comparative Analysis (QCA) investigating environmental migration and other rural drought adaptation strategies in Baja California Sur, Mexico

1 might be more common in predominantly rural societies (Lucas 2016), and new trends in return migration from the

2 United States to Mexico might reveal new patterns in the future (Masferrer and Roberts 2016). That said, studies of

3 rancheros who have migrated and are presently living in cities would further illuminate our understanding of

4 ranchero decisions.

There are several remaining questions that our analysis did not address. According to the analysis, female education seemed to play a role in relation to financial diversity, owning livestock, and land titles in households who

\section{Discussion and conclusion}

The study tested the trait configurations of ranchero households and their drought strategy choices in the last severe drought. Specifically, we examined households who adopted environmental migration, farm changes, and off-farm work to respond to the drought. We further broadened the concept of migration to include any household member who had left during the drought years for any reason to account for possible indirect drivers of migration. Our findings indicate the vast majority of respondents indicated that they did something (86\%) to respond to the last drought and that the most frequent responses were acquiring off-farm work and changing farm practices. Although rancheros have historically adapted to droughts through migration, our study showed that this was a less favorable option - only $15 \%$ of households reported that they migrated specifically because of the drought. A more sedentary approach to drought gives us reason to believe that an opportunity for sustainable ranching and watershed conservation exists in this area.

Using previously published household surveys on drought adaptation (Alscher 2010; de Janvry and Sadoulet 2001; Eakin 2005; Ellis 2000; Gray 2009; Laczko and Aghazarm 2009; Liverman 1999; Massey et al. 
A Qualitative Comparative Analysis (QCA) investigating environmental migration and other rural drought adaptation strategies in Baja California Sur, Mexico

1 2010; Narayan and Pritchett 1999; Nelson et al. 2005; Saldaña-Zorrilla 2008; Vilei and Dabbert 2007; Vincent and

2 Cull 2010), we identified six key household traits that are theoretically associated with drought response and added

3 three culturally specific variables. We found that there were some notable differences in the combination of

4 household traits of those who responded to the drought and those who did nothing, and there were also differences

5 in household make-up depending on the type of strategy adopted. Contrary to the robust literature on the role that

6 social capital plays in adaptation in general (Narayan and Pritchett 1999), our study did not find strong associations

7 between social capital and other household traits in relation to drought outcomes (but did find an association in

8 general household migration). We used "membership in a formal organization" as a measure of social capital, a

9 common indicator in the extant research (Narayan and Pritchett 1999) (we also tested the survey questions "Do you

10 have an address or phone number of someone in another place who you could contact right now if you needed to

11 migrate?" and "Do you think you would be able to find a travel companion if you needed to migrate right now?" as

12 measures of social capital with even weaker results). Perhaps this indicates a need to increase social capital among

13 these households. After all, rancheros have a reputation for being remote, self-sufficient, and individualistic, as

14 described by our local NGO informants and interviewees: "Some do [help during droughts], very little. Everybody

15 stays in his own ranch." However, in practice it was clear that rancheros use social networks to a large extent, for

16 example, some rancheros would not agree to an interview until we were introduced by a neighbor. This could

17 suggest that the way that social capital is measured by researchers does not capture the types of social bonds in these

18 communities, and future research could focus on culturally appropriate social capital measures designed by

19 rancheros (for an example of social water management on mainland Mexico, see Navarro-Navarro, Moreno-

20 Vazquez, and Scott, 2017).

21 Meanwhile, in line with the literature (de Janvry and Sadoulet 2001; Liverman 1999; Massey et al. 2010),

22 financial diversity and owning land and livestock were the most important traits for our households for adopting

23 drought strategies, following economic theories suggesting that the power to exchange assets increases adaptive

24 capacity. And yet, we would be hard-pressed to declare with any certitude that rancheros with quantitatively more

25 assets are less vulnerable. In spite of variability among ranchero households, it is clear that more prolonged, severe, 26 and frequent droughts in the semi-arid desert of Baja California Sur will place rancheros at risk of loss of the ability 27 to ranch and mobility in general. 


\section{A Qualitative Comparative Analysis (QCA) investigating environmental migration and other rural drought adaptation strategies in Baja California Sur, Mexico}

Our work on better understanding the make-up of households and their adoption of drought strategies is motivated by recent drought policy reform globally and in Mexico (UNCDD, 2013; Federman, Cortés, and Pérez, 2014). We highlight factors by those working in this broader area, as well as those concentrating their efforts at the intersection of drought adaptation and environmental migration literatures. First, we need a better appreciation of the specific cultural context in which rancheros experience drought and further emphasize the need for re-framing rancheros as welfare receivers requiring drought assistance to innovators who are adapting in place and are valuable actors in overall watershed health (Brunson and Huntsinger 2008, Wright et al. 2016). Our study shows that obtaining off-farm work was a popular choice for rancheros while environmental migration was less so. To better understand the adoption of drought strategies, we need to understand the variability of household traits among rural small landholders. Given that the respondents in this study continue to identify as rancheros despite choosing alternative livelihoods to respond to drought, our findings suggest that, as Vadjunec et al. (2016) have proposed, smallholder identity may be more of a state of mind than based on a certain number of hectares owned. The findings that households are heterogeneous in their trait make-up and drought outcomes add further evidence to the claim that households within natural resource based communities are not monolithically vulnerable or that vulnerability is environmentally determined (Flint and Luloff, 2005).

Second, we need to better understand how the developing urban water infrastructure changes the options available to rancheros (author, et al, 2016). We found a clear distinction between households who could drive to the city or access piped water and those who relied on surface water for human consumption. In fact, 21 households (13\%) told us that they regularly bring water from the city or use potable water from pipes for animal consumption as well. All of these households were in the La Paz municipality, giving us reason to believe that urban expansion, whether considered "encroachment" or "development," is radically changing the ranchero way of life in this area. Given the influence of urbanization and sensitivity to global environmental change, our findings are further aligned with Vadjunec et al. (2016)'s assessment that complex power dynamics should cause us to think about smallholders as "relational and fluid" rather than a static way of life.

Third, we believe QCA lends a valuable perspective to understanding the complexity of household traits and adoption of drought strategies. QCA provides the means to compare household trait make-up on drought responses while adding an important dimension to the variety of ways that rural households adapt to changing 


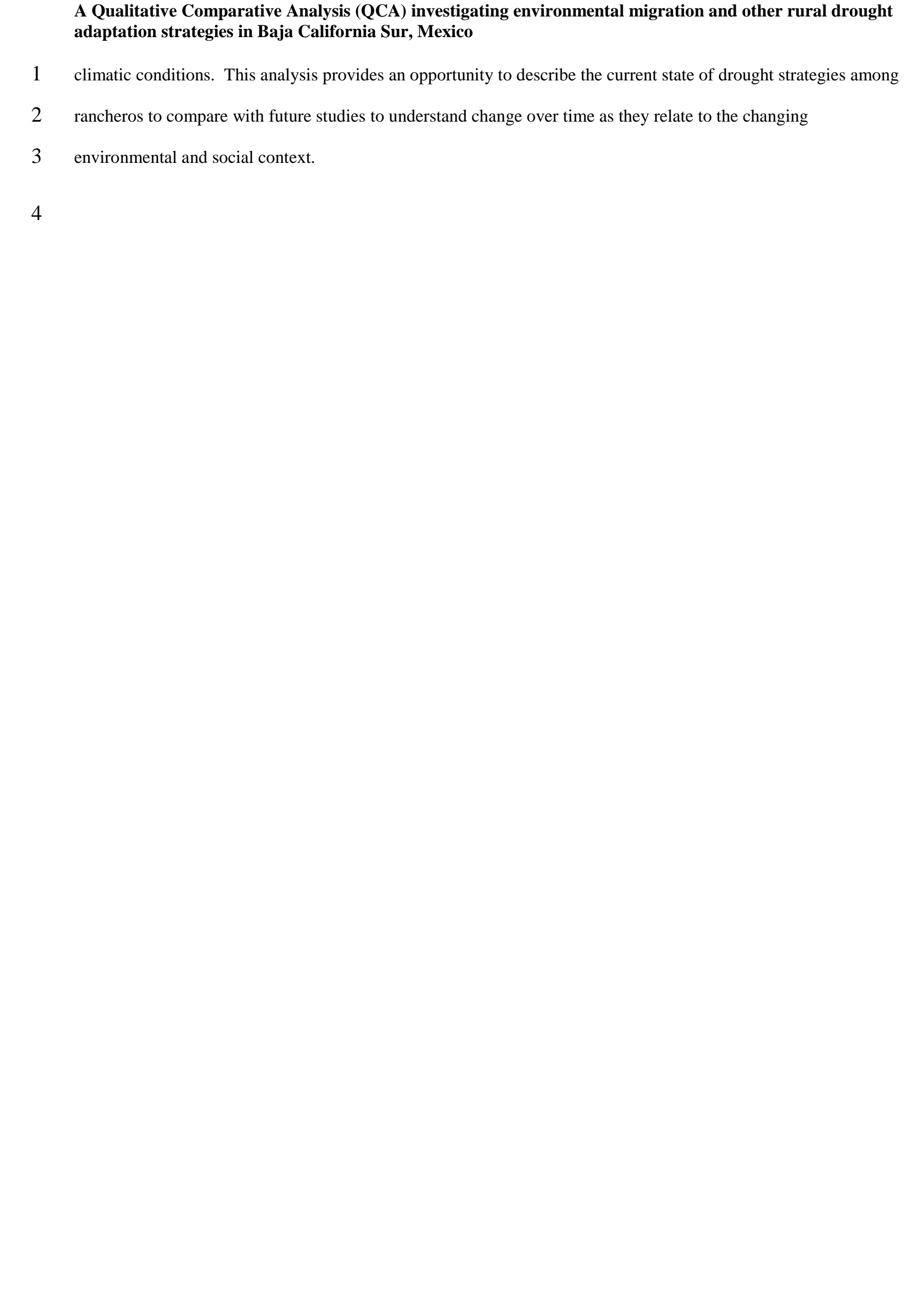


A Qualitative Comparative Analysis (QCA) investigating environmental migration and other rural drought adaptation strategies in Baja California Sur, Mexico

\section{Acknowledgements}

The authors would like to thank the respondents for giving their time to this study. We would like to acknowledge the following for their assistance in translation and transcription: Vinnie Enrique Caicero, Yuridia Davis, Chris Estrada, Joel Coronado Gaxiola, Mariana Ledesma, Irene López, Carlos Mancilla, Luz Fabiola Armenta Martínez, Laura Morales, Carlos Nava, Arry Gonzalez Peralta, Nancy Rubio, Cenia Alemán Sarabia, Jesenia Torres, Mabilia Urquidi, and Paola Bonilla Yee. Thank you to the following guides in the field: Aníbal López, Profesora Rosario Almeida Cruz, Ezequiel, Jesús “Chuy,” and the non-profits Niparajá A.C. (http://niparaja.org/) and Raíces Vivas (http://www.fundacionraicesvivas.org/), without whom this project would not have been possible. Mabilia Urquidi produced the map.

\section{Compliance with Ethical Standards}

The authors declare that they have no conflict of interest.

This research was approved by the Colorado State University Institutional Review Board Protocol 12-3573H. 


\section{References}

Afifi T Liwenga E, Kwezi L (2013) Rainfall-induced crop failure, food insecurity and out-migration in SameKilimanjaro, Tanzania. Climate and Dev: 1-8. doi: 10.1080/17565529.2013.826128

Agrawal A (2010) Local institutions and adaptation to climate change. Social Dimensions of Climate Change: Equity and Vulnerability in a Warming World. Washington DC, World Bank, 173-198

Alscher S (2010) Environmental factors in Mexican migration: The cases of Chiapas and Tlaxcala. Environ, Forced Migr and Soc Vulnerability. Springer 171-185. doi: 10.1007/978-3-642-12416-7_13

Blankespoor B, Dasgupta S, Laplante B, Wheeler D (2010) The economics of adaptation to extreme weather events in developing countries. Center for Global Development Working Paper (199). doi: 10.2139/ssrn.1542720

Brunson MW, Huntsinger L (2008) Ranching as a conservation strategy: can old ranchers save the New West? Rangeland Ecology \& Management 61(2):,137-147. doi: 10.2111/07-063.1

Cariño, M, Castorena L, Maya Y, Wurl J, Urciaga J, Breceda A (2012) Transformación de los ecosistemas áridos para su uso agrícola en Baja California Sur, México. Un análisis desde la historia ambiental. Historia Agraria, 56 (Abril): 81-106 ISSN: 1139-1472

Cavazos T, Arriaga-Ramírez S (2012) Downscaled climate change scenarios for Baja California and the North American monsoon during the twenty-first century. J of Climate 25(17):5904-5915. doi: 10.1175/JCLI-D$11-00425.1$

Chort I (2014) Mexican migrants to the US: What do unrealized migration intentions tell us about gender inequalities? World dev 59:535-552. doi: 10.1016/j.worlddev.2014.01.036

CONAGUA (2013) Diaro Oficial de la Federacion. DECLARATORIA de Desastre Natural por la ocurrencia de sequía severa del 1 de mayo al 30 de noviembre de 2011 en los municipios de La Paz, Los Cabos y Loreto del Estado de Baja California Sur.

de Janvry A, Sadoulet, E (2001) Income strategies among rural households in Mexico: The role of off-farm activities. World dev 29(3):467-480. doi: 10.1016/S0305-750X(00)00113-3

Eakin H (2005) Institutional change, climate risk, and rural vulnerability: Cases from Central Mexico. World Dev, 33(11):1923-1938. doi: 10.1016/j.worlddev.2005.06.005

Ellis F (2000) Rural livelihoods and diversity in developing countries. Oxford University Press

Federman DK, Cortés FIA, Pérez, ML (2014) Constructing a framework for National Drought Policy: The way forward in Mexico. Weather and Climate Extremes (3):90-94 doi:10.1016/j.wace.2014.04.003

Flint CG, Luloff AE (2005) Natural resource-based communities, risk, and disaster: An intersection of theories. Society and Natural Resources, 18(5):399-412. doi:10.1080/08941920590924747

Gray C (2009) Environment, land, and rural out-migration in the Southern Ecuadorian Andes. World dev, 37(2):457-468. doi: 10.1016/j.worlddev.2008.05.004

Gray C, Mueller V (2012) Drought and population mobility in rural Ethiopia. World dev, 40(1):134-145. doi: 10.1016/j.worlddev.2011.05.023

Kelly PM, Adger WN (2000) Theory and practice in assessing vulnerability to climate change andFacilitating adaptation. Climatic Change 47(4):325-352. doi: 10.1023/A:1005627828199

Kniveton DR (2008) Climate change and migration: improving methodologies to estimate flows. United Nations. http://sro.sussex.ac.uk/id/eprint/12069

Kok M, Lüdeke M, Lucas P, Sterzel T, Walther C, Janssen P, Sietz D, de Soysa I (2016) A new method for analysing socio-ecological patterns of vulnerability Regional Environmental Change 16:229-243. doi: 10.1007/s 10113-014-0746-1

Kusek JZ, Rist RC (2004) Ten steps to a results-based monitoring and evaluation system: a handbook for development practitioners. World Bank Publications

Laczko F, Aghazarm C (2009) Migration, environment and climate change: Assessing the evidence. International Organization for Migration Geneva. http://www.cefeb.org/jahia/webdav/site/afd/shared/PORTAILS/PAYS/MEDITERRANEE/MigrationMENA/3-Lazcko.pdf

Leighton M (2011) Drought, desertification and migration: Past experiences, predicted impacts and human rights issues. Migr and Climate Change 331-358

Liverman DM (1999) Vulnerability and adaptation to drought in Mexico Nat Resources J 39:99

Lucas R (2016) Internal Migration in Developing Economies: An Overview. Retrieved from http://www.knomad.org/docs/working_papers/KNOMAD\%20Working\%20Paper\%206_Lucas_Internal\%2 OMigration.pdf 
Mardero S, Schmook B, Radel C, Christman Z, Lawrence D, Millones M, Nickl E, Rogan J, Schneider L (2015) Smallholders' adaptations to droughts and climatic variability in southeastern Mexico. Environ Hazards 14(4):271-288. doi: 10.1080/17477891.2015.1058741

Masferrer C, Roberts BR (2016) The Changing Patterns of Return Migration from the USA to Mexico and Their Policy Implications. In: Migration in an Era of Restriction and Recession. Springer: 235-258. doi: 10.1007/978-3-319-24445-7_12

Massey DS, Axinn WG, \& Ghimire DJ (2010) Environmental change and out-migration: Evidence from Nepal. Popul and Environ 32(2-3):109-136. doi: 10.1007/s11111-010-0119-8

McLeman R, Mayo D, Strebeck E, Smit B (2008) Drought adaptation in rural eastern Oklahoma in the 1930s: lessons for climate change adaptation research. Mitig and adapt strateg for glob change 13(4): 379-400. doi: 10.1007/s11027-007-9118-1

McLeman RA, Ploeger SK (2012) Soil and its influence on rural drought migration: insights from Depression-era Southwestern Saskatchewan, Canada. Popul and Environ 33(4):304-332. doi: 10.1007/s11111-011-0148-y

Mendoza B, Velasco V, and Jáuregui E (2006) A study of historical droughts in southeastern Mexico Journal of climate 19.12: 2916-2934. doi: http://dx.doi.org/10.1175/JCLI3726.1

Narayan D, Pritchett L (1999) Cents and sociability: Household income and social capital in rural Tanzania. Econ dev and cult change 47(4):871-897. doi: 10.1086/452436

Navarro-Navarro LP, Moreno-Vazquez JL, Scott CA. (2017) Social networks for management of water scarcity: Evidence from the San Miguel Watershed, Sonora, Mexico. Water Alternatives 10.1: 41.

Nelson R, Kokic P, Elliston L, King JA (2005) Structural adjustment: a vulnerability index for Australian broadacre agriculture. Agric Commod 12(1):171. https://www.example.edu/paper.pdf

Niparajá, S. d. H. N. d. (2014) Retrieved January 28, 2014, from http://www.niparaja.org/

Pugatch T, Yang D (2011) The impact of Mexican immigration on US labor markets: evidence from migrant flows driven by rainfall shocks. Retrieved from https://www.maxwell.syr.edu/uploadedFiles/econ/seminars/Dean\%20Yang\%20Impact\%20of\%20mexican\%20Immigration\%20on\%20US\%20Labor\%20Markets.pdf

Qin H (2010) Rural-to-urban labor migration, household livelihoods, and the rural environment in Chongqing Municipality, Southwest China. Hum ecol 38(5):675-690. doi: 10.1007/s10745-010-9353-z

Ragin C (1987) The comparative method: Moving beyond qualitative and quantitative methods Berkeley: University of California

Ragin C (2006) Set relations in social research: Evaluating their consistency and coverage Political Analysis 14:291 310 doi:10.1093/pan/mpj019

Ragin C (2014) The comparative method: Moving beyond qualitative and quantitative strategies. Univ of California Press

Rihoux B (2006) Qualitative comparative analysis (QCA) and related systematic comparative methods recent advances and remaining challenges for social science research. Int Sociol 21(5):679-706. http://journals.sagepub.com/doi/pdf/10.1177/0268580906067836

Rocha J, Yletyinen J, Biggs R, Blenckner T, Peterson, G (2015) Marine regime shifts: drivers and impacts on ecosystems services. Philosophical Transactions of the Royal Society B, 370(1659), doi: $10.1098 /$ rstb.2013.0273

Romero Lankao P, Qin H (2011) Conceptualizing urban vulnerability to global climate and environmental change. Curr opin in environ sustain 3(3):142-149. doi: 10.1016/j.cosust.2010.12.016

Saldaña-Zorrilla SO (2008) Stakeholders' views in reducing rural vulnerability to natural disasters in Southern Mexico: Hazard exposure and coping and adaptive capacity. Glob environ change 18(4):583-597. doi: 10.1016/j.gloenvcha.2008.09.004

Riosmena F, Nawrotzki RJ, Hunter LM (2013) Rainfall trends, variability and US migration from rural Mexico: evidence from the 2010 Mexican census. Work Pap., Inst. Behav. Science, Univ. Colo., Boulder.

Schneider CQ, Wagemann C (2010) Standards of good practice in qualitative comparative analysis (QCA) and fuzzy-sets. Comp Sociol 9(3):397-418. doi: 10.1163/156913210X12493538729793

Thiem A, Dusa A (2013) QCA: A package for qualitative comparative analysis The R Journal 5:87-97

UNCDD (United Nations Convention to Combat Desertification), Food and Agriculture Organization (FAO) of the United Nations, World Meteorological Organization (WMO) (2013) High-Level Meeting on National Drought Policy (HMNDP) Science Document: Best Practices on National Drought Management Policy. Geneva

Vadjunec J, Radel C, Turner II BL (2016) Introduction: The continued importance of smallholders today. Land 5(4), 34; doi:10.3390/land5040034 
A Qualitative Comparative Analysis (QCA) investigating environmental migration and other rural drought adaptation strategies in Baja California Sur, Mexico

Vilei S, Dabbert S (2007) Locally derived indicators for evaluating sustainability of farming systems. Paper presented at the Proceedings Deutscher Tropentag. http://www.tropentag.de/2007/abstracts/full/485.pdf

Vincent K, Cull T A Household Social Vulnerability Index (HSVI) for evaluating adaptation projects in developing countries. In: PEGNet conference, 2010. pp 02-03

Wamsler, C (2011) Climate change, adaptation and formal education: The role of schooling for increasing societies' adaptive capacities, in: The selected works of Christine Wamsler. Lund University, Laxemburg, Austria. https://works.bepress.com/christine_wamsler/27/download/

Wright J, Milner-Gulland EJ, Hill NA, Roe D, Rowcliffe M, Kumpel N, Day M, Booker F (2016) Reframing the concept of alternative livelihoods. Conserv Biol 30(1):7-13. doi: 10.1111/cobi.12607 
A Qualitative Comparative Analysis (QCA) investigating environmental migration and other rural drought adaptation strategies in Baja California Sur, Mexico 


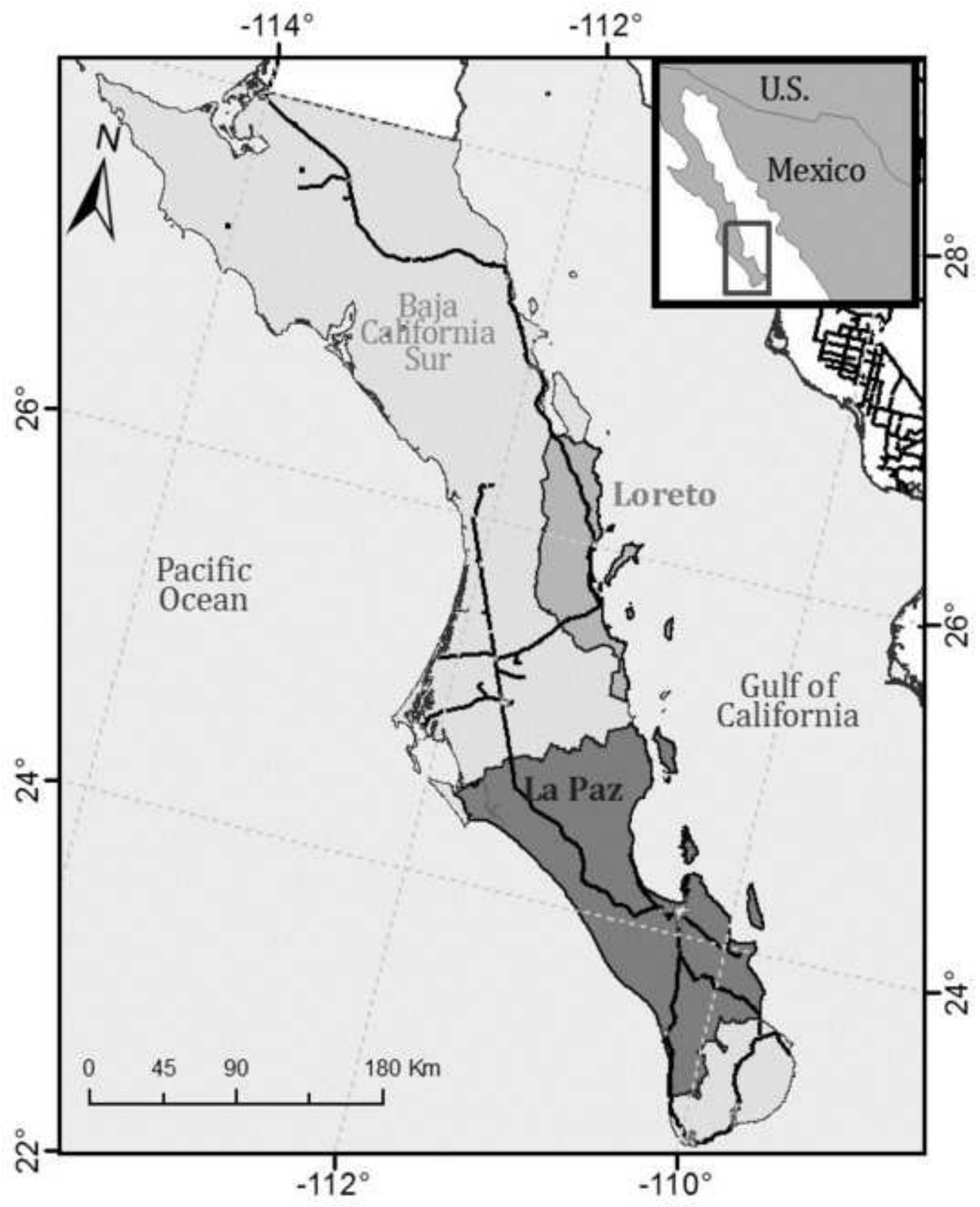



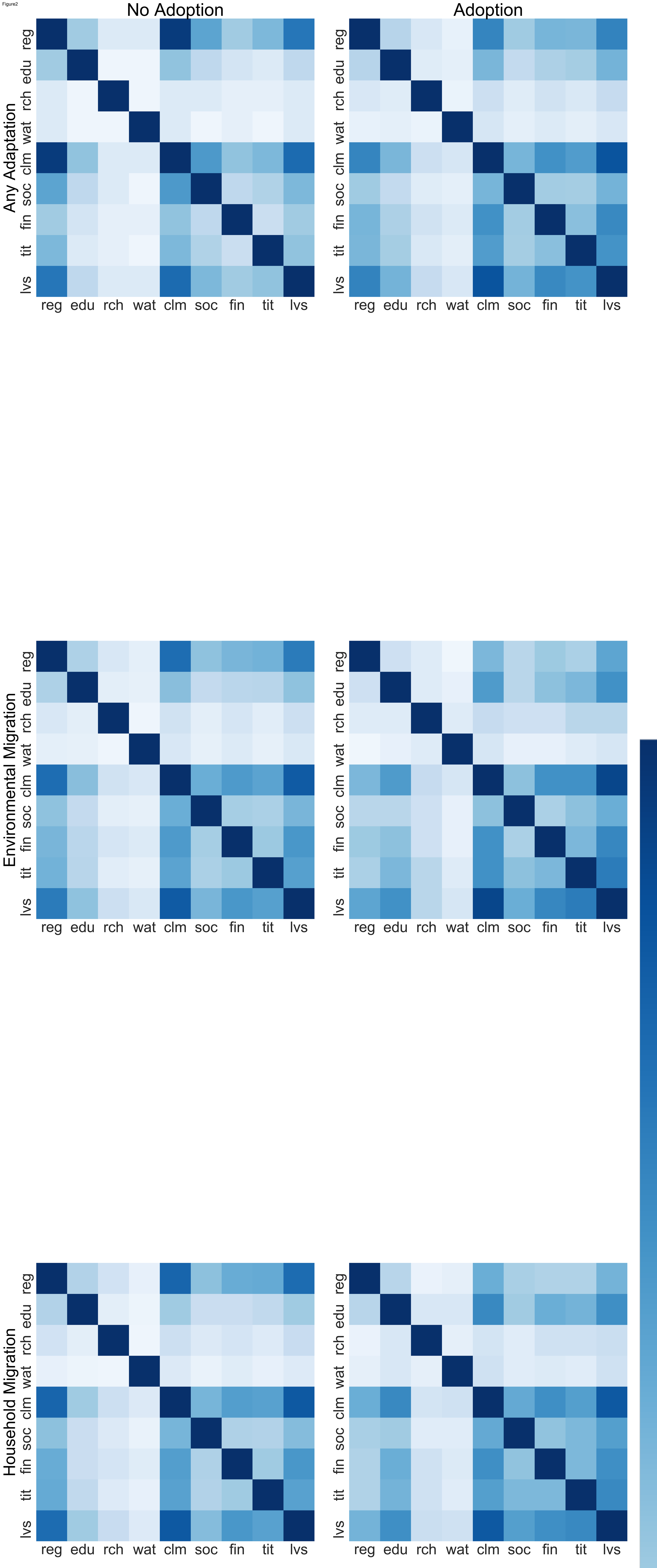

reg edu rch wat clm soc fin tit Ivs
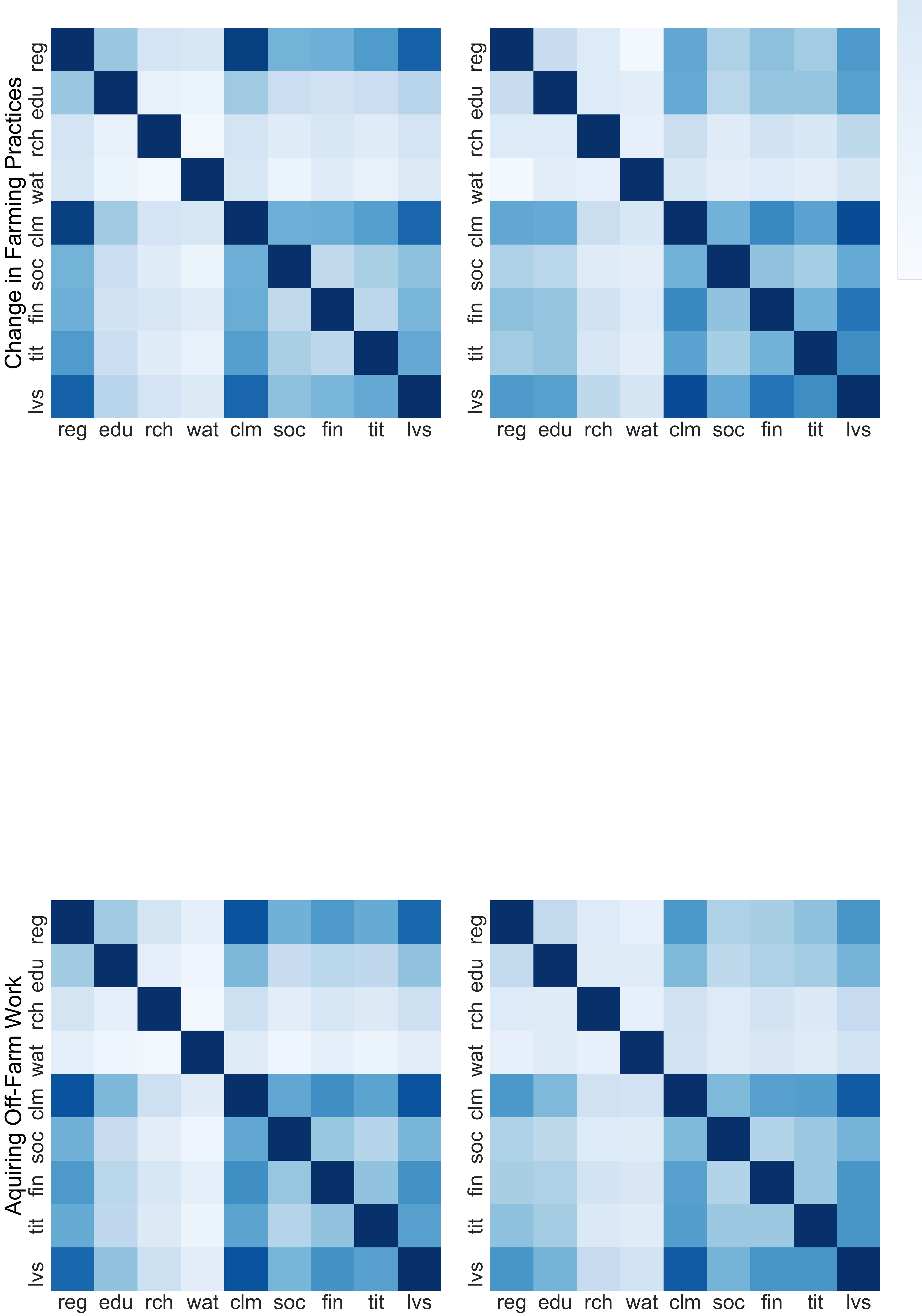


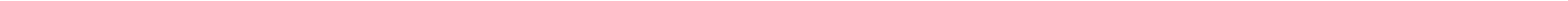


Online Resources- Supplementary Material

A Qualitative Comparative Analysis (QCA) investigating environmental migration and other rural drought adaptation strategies in Baja California Sur, Mexico

Regional Environmental Change

Melissa Haeffner, PhD, Utah State University (Author for communications)

0730 Old Main Hill, Logan, Utah 84332 melissa.haeffner@ usu.edu

Jacopo Baggio, PhD, Department of Environment and Society, Utah State University

Kathleen Galvin, PhD, Department of Anthropology, Colorado State University

\section{Contents}

1 Household survey design

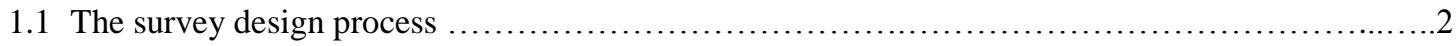

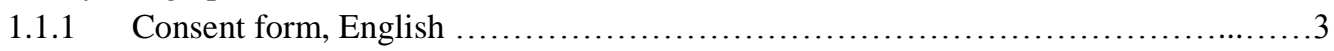

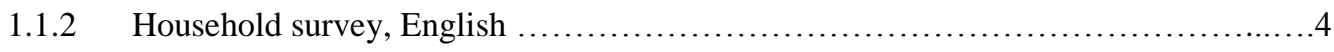

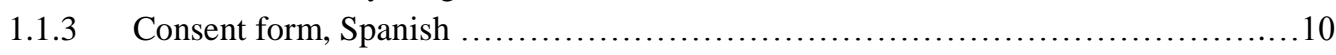

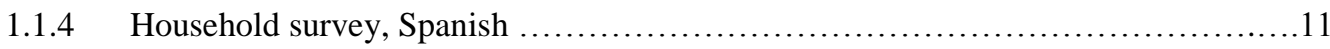

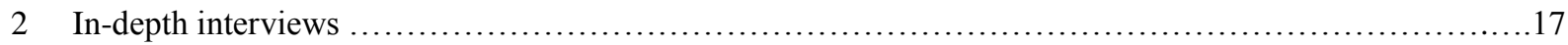

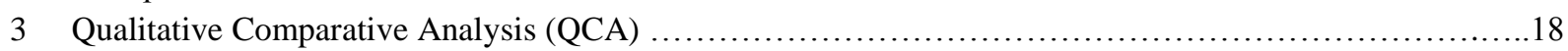

Table 1. Household traits and definitions.....................................18

Table 2. Household traits presence and absence of total sample and of non-adopting households...................................................................19

Table 3. Fraction of times a trait is present in consistent solution leading to presence and absence in all QCA performed ................................... 20

Table 4. QCA Solution sets tables ............................................21

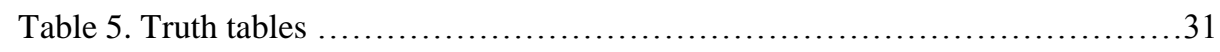

Table 6. Facilitating and hindering traits for outcomes ..........................43

Figure 1. Percentage of presence and absence cases of household traits by the types of adaptation strategies we measured (Complete cases).............47

Figure 2. Percentage of presence and absence cases of household traits by the types of adaptation strategies we measured (Missing=0 cases)............48

Figure 3. Percentage of presence and absence cases of household traits by the types of adaptation strategies we measured (Missing=1 cases)............49

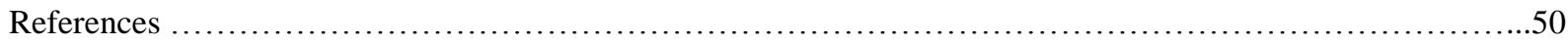




\section{Household survey design}

\subsection{The survey design process}

Once the systematic process described in the paper was used to design the survey, several steps were taken to ensure that the survey was culturally appropriate and sensitive to the local community. First, local experts reviewed the survey for community appropriateness then the survey was piloted twice with ranching households. Pilot studies are used as a means of learning what works and what does not, to test the quality of data sources, to test collection and analysis strategies, as well as determining necessary data that do not yet exist (Kusek and Rist 2004). A few culturally specific factors emerged from this process that informed our measures. It is important to note that primary education facilities exist in these rural communities, but students must leave the community for secondary education or beyond. This often involves the student living in a boarding house in the city during the weeks and returning home on weekends.

The empirical basis for this paper is field work collected in the dry season (July and August 2013) to be representative of water stress and immediately after a federally declared drought ended. Sample size for each location were calculated for a 95\% confidence level with a $+/-5 \%$ margin of error. Participants were contacted in their homes using a door-to-door sampling method. Surveys were conducted in Spanish with a team of twelve translators from the Universidad Autónoma de Baja California Sur who read the questions and answer choices aloud and helped participants mark their choices. Translators were required to attend a training before embarking on the fieldwork to ensure consistency, reduce the risk of question leading, and maintain best practices in obtaining informed consent. In each community, a local informant introduced us to households to establish rapport. Each survey took approximately one hour to complete. Two bilingual team members cleaned the data and doubletranslated open-ended responses. A 90\% response rate was obtained, representing a total of 163 ranchero households and 657 individual family members. We coded the household trait or drought strategy in question as presence (1) or absence (0). Below are the questionnaires in English and Spanish along with the accompanying consent forms. 


\subsubsection{Consent form, English}

Consent to Participate in a Research Study, Colorado State University

TITLE OF STUDY: Drought-induced human migration in Mexico

PRINCIPAL INVESTIGATOR: Kathleen Galvin, Ph.D., Professor, Department of Anthropology,

CO-PRINCIPAL INVESTIGATOR: Melissa Haeffner, Graduate Degree Program in Ecology, Doctoral student,

melissahaeffner@gmail.com

You have been selected to participate in this research because there are high levels of dryness and also high levels of migration in your area. Households in this community have been selected at random to discuss whether or not these two things are related. Ideally, the head of household will fill out the survey. If the head is not available, the spouse or other adult is asked to fill out the survey. This study is being conducted by Colorado State University. The purpose of this study is to understand how drought conditions have affected you, and to study how people decide to migrate based on these conditions.

The survey will be conducted at your home, and is expected to last less than 1 hour. You will be asked to fill out a questionnaire in Spanish or English. If you cannot read and write in either of these languages, the researcher will ask you the questions in one of these languages and record your answers. It is requested that only persons 18 years or older fill out this survey. It is best if the head of household, or an adult family member, complete the survey.

$>$ There are no known risks to filling out this survey. If at any time you feel uncomfortable, you can skip any question or stop completely.

$>$ It is not possible to identify all potential risks in research procedures, but the researchers have taken reasonable safeguards to minimize any known and potential, but unknown, risks.

$>$ There are no direct benefits to you as a result of completing this survey. However, it is anticipated that the knowledge generated from this study may benefit all of those suffering from drought. Your participation in this research is voluntary. If you decide to participate in the study, you may withdraw your consent and stop participating at any time without penalty or loss of benefits to which you are otherwise entitled.

$>$ We will keep private all research records that identify you, to the extent allowed by law. Your information will be combined with information from other people taking part in the study. When we write about the study to share it with other researchers, we will write about the combined information we have gathered. You will not be identified in these written materials. We may publish the results of this study; however, we will keep your name and other identifying information private. We will make every effort to prevent anyone who is not on the research team from knowing that you gave us information, or what that information is. For example, your name will be replaced by a numerical code, for example, 0001, and this will be stored electronically in a password-protected file. After seven years, all data records will be destroyed.

Before you decide whether to accept this invitation to take part in the study, please ask any questions that might come to mind now. Later, if you have questions about the study, you can contact the investigator, Melissa Haeffner atmelissahaeffner@gmail.com.or AndrewJones, Baja Bioregional: ajventure@gmail.com. If you have any questions about your rights as a volunteer in this research, contact Janell Barker, Human Research Administrator at 970-491-1655. We will give you a copy of this consent form to take with you. This consent form was approved by the CSU Institutional Review Board for the protection of human subjects in research on August 8, 2012.

Your signature acknowledges that you have read the information stated and willingly sign this consent form. Your signature also acknowledges that you have received, on the date signed, a copy of this document containing $\underline{2}$ pages.

Signature of participant

Signature of research staff

\section{Printed name}

Printed name
Date

Date 
Small landholder Questionnaire

Date:

Ranch Community: Larger Region:

Municipality:

GPS: UTM Zone

Easting

Northing

Interview \#

\begin{tabular}{|c|c|c|c|c|c|c|c|c|c|c|c|}
\hline & 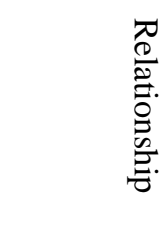 & 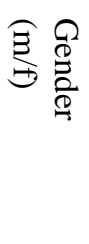 & $\underset{0}{\overrightarrow{0}}$ & 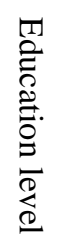 & 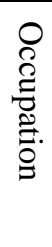 & 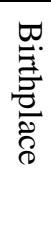 & 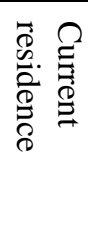 & 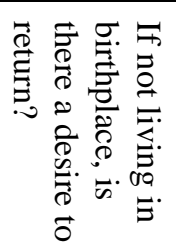 & 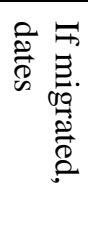 & 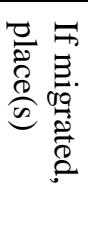 & 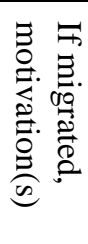 \\
\hline Person 1 & $\begin{array}{l}\text { Head of } \\
\text { household }\end{array}$ & & & & & & & & & & \\
\hline Person 2 & & & & & & & & & & & \\
\hline Person 3 & & & & & & & & & & & \\
\hline Person 4 & & & & & & & & & & & \\
\hline Person 5 & & & & & & & & & & & \\
\hline Person 6 & & & & & & & & & & & \\
\hline
\end{tabular}


1. What is your main water source for human consumption?
a. $\square$ surface water (e.g., arroyo)
b. $\square$ well
c. $\square$ spring
d. $\square$ other
e.

2. What is your main water source for animals?
a. $\square$ surface water (e.g., arroyo)
b. $\square$ well
c. $\square$ spring
d. $\square$ other

3. Do you conserve water? $\square$ Yes, how?

4. Do you hold a concession with CONAGUA for any water use (e.g., tubewell)?

5. Have you had to change where you get your water from in the last 10 years?

$\square$ Yes why?

$\square$ No

6. Do you think the weather has gotten more unpredictable over the last 10 years? $\square$ Yes why?

7. What would you say is the main environmental threat to your life?

8. During the last drought, did you take any of the following actions to mitigate the negative effects?
a. $\square$ Switched from free-range to corralled animals
b. $\square$ Switched from cows to goats
c. $\square$ Planted more feed for animals
d. $\square$ Stored feed
e. $\square$ Planted more produce to sell
f. $\square$ Planted food for personal use
g. $\square$ Migrate
h. $\square$ Obtained PET work
i. $\square$ Obtained other work outside of the ranch
j. $\square$ Worked with other families to share resources
k. $\square$ Other

9. Are you currently doing any of the following activities to plan for a severe drought in the future?
a. $\square$ Plan to migrate
b. $\square$ Store water
c. $\square$ Conserve water
d. $\square$ Diversify income sources
e. $\square$ Invest in education
f. $\square$ Work more closely with people in the community
g. $\square$ Other 
1. Do you have an address or phone number of someone in another place who you could contact right now if you needed to migrate?

$$
\square \text { Yes } \quad \square \text { No }
$$

2. Do you think you would be able to find a travel companion if you needed to migrate right now?
$\square$ Yes
$\square$ No

3. Are you a member of any organizations (e.g., COTAS Comité Técnico de Aguas Subterráneas, school board, other)?

$\square$ Yes, which?

$$
\square \text { No }
$$

4. How do you obtain information about droughts?

a. $\square$ Environment signals (e.g., previous rains, animal behavior, change in vegetation, etc.) please

$$
\text { explain }
$$

b. $\square$ Family

c. $\square$ Other ranchers

d. $\square$ Radio

e. $\square \mathrm{TV}$

f. $\square$ Other

5. Who do you feel is the most responsible for helping your household in times of drought?
a. $\square$ Myself
b. $\square$ My community
c. $\square$ Government, which agency?
d. $\square$ NGOs, which?
e. $\square$ Other 
1. Please indicate the percentage of your income adding up to $100 \%$.

\begin{tabular}{|l|l|l|}
\hline A & Ranching & \\
\hline B & PET & \\
\hline C & Other job & \\
\hline D & Sale of produce & \\
\hline E & Family business (restaurant, handicrafts, etc.) & \\
\hline F & Remittances & \\
\hline G & Government aid & \\
\hline H & Pension & \\
\hline I & Savings & \\
\hline J & Loans & \\
\hline K & Other & \\
\hline & TOTAL & $100 \%$ \\
\hline
\end{tabular}

2. How do you expect to finance recovery from the next drought?

a. $\square$ Personal savings

b. $\square$ Government help, which agency?

c. $\square$ Other

3. Do you have insurance for your land? $\quad \square$ Yes, with whom?

$\square$ No, why not?

4. Do you have insurance for your animals? $\square$ Yes, with whom?

$\square$ No, why not?

5. Do you have disaster insurance?

$\square$ Yes, with whom?

$\square$ No, why not?

6. If you do not have insurance, what would make you more likely to get insurance in the future?

7. Do you have access to credit or loans?

8. Do you have any concessions/contracts with CFE? $\square$ Yes, with whom?

$\square$ Yes $\square$ No

$\square$ No 


\section{Cont'd Household survey, English}

1. Do you have a land title to your property?

$$
\square \text { Yes } \quad \square \text { No }
$$

2. How many hectares do you have access to?
a. $\square 0$
b. $\square 1-5$
c. $\square 6-10$
d. $\square$ more than 20

3. How many cows do you own?
a. $\square 0$
b. $\square 1-10$
c. $\square$ 11-20
d. $\square$ more than 20

4. How many goats do you own?
a. $\square 0$
b. $\square 1-10$
c. $\square$ 11-20
d. $\square$ more than 20

5. How many mules do you own?
a. $\square 0$
b. $\square$ 1-10
c. $\square 11-20$
d. $\square$ more than 20

6. How many horses do you own?
a. $\square 0$
b. $\square$ 1-10
c. $\square$ 11-20
d. $\square$ more than 20

7. How many chickens do you own?
a. $\square 0$
b. $\square$ 1-10
c. $\square 11-20$
d. $\square$ more than 20

8. Do you mainly grow your own food to eat, or do you mainly buy food? a. $\square$ Grow food

9. Do you have stored water for the future? (functions and holds water)
a. $\square$ Bordo
b. $\square$ Presa
c. $\square$ Other

10. How far, in hours, do you have to travel to the nearest market? to sell to buy 
Cont'd Household survey, English

1. Do you have a birth certificate? $\square$ Yes $\square$ No

2. Do you have a passport? $\quad \square$ Yes $\square$ No

3. Do you have health insurance? $\square$ Yes $\square$ No

4. Does anyone in your family have a disability or chronic illness? $\quad \square$ Yes $\square$ No

5. If you thought you had to leave your community, what would drive you to do so?
a. $\square$ Natural disaster
b. $\square$ Job
c. $\square$ School
d. $\square$ Lifestyle
e. $\square$ Health reasons
f. $\square$ Other
g. $\square$ Would never leave, under any circumstance

6. Have you received training from outside experts?
a. $\square$ Water conservation, who?
b. $\square$ Economic development, who?
c. $\square$ Weather forecasting, who?
d. $\square$ Other, who?
e. $\square$ None

7. In which areas would you like to receive services?

Thank you for your participation! 


\subsubsection{Consent form, Spanish}

\section{Consentimiento para participar en una investigación de la Universidad Estatal de Colorado}

Investigador PRINCIPAL: Kathleen Galvin, Ph.D., profesor, departamento de Antropología, kathy@nrel.colostate.edu CO-PRINCIPAL investigadora: Melissa Haeffner, programa graduado de licenciatura en ecología, estudiante de doctorado, melissahaeffner@gmail.com.

La encuesta se llevará a cabo en su casa y se espera que dure menos de 1 hora.

Se solicita que sólo las personas de 18 años o mayores llenen esta encuesta. Es mejor si la cabeza del hogar, o un miembro adulto de la familia, completa la encuesta.

- No hay riesgos conocidos por llenar esta encuesta. Si en cualquier momento se siente incómodo, puede omitir cualquier pregunta o detener completamente la encuesta. No es posible identificar todos los riesgos potenciales en los procedimientos de investigación, pero los investigadores han tomado precauciones razonables para minimizar los riesgos conocidos y los riesgos potenciales pero desconocidos.

- Por completar esta encuesta usted no tendra ningun beneficio directo. Sin embargo, se prevé que el conocimiento generado en este estudio puede beneficiar a todos los que sufren de sequía. Su participación en esta investigación es voluntaria. Si decide participar en el estudio, puede retirar su consentimiento y dejar de participar en cualquier momento sin penalización o pérdida los beneficios que le corresponden

○ Todos los registros de la investigación que lo identifican a usted los mantendremos confidenciales, hasta lo permitido por la ley. Su información se combinará con información de otras personas que participan en el estudio. Cuando escribamos el estudio para compartirlo con otros investigadores, vamos a escribir acerca de la información combinada que hemos reunido. Usted no será identificado en estos materiales escritos. Quiza publiquemos los resultados de este estudio; Sin embargo, mantendremos su nombre y otra información de identificación confidencial. Haremos todo lo posible para evitar que cualquier persona que no está en el equipo de investigación sepa que usted nos dio información, o lo que es esa información. Por ejemplo, su nombre será sustituido por un código numérico, por ejemplo, 0001, y esto se almacenará electrónicamente en un archivo protegido con contraseña. Después de siete años, se destruirán todos los registros de datos.

Antes de decidir si desea aceptar esta invitación a participar en el estudio, por favor preguntar cualquier duda que pudiera venirle a la mente ahora. Más tarde, si usted tiene preguntas acerca del estudio, puede contactarse con el investigador, Melissa Haeffner en melissahaeffner@gmail.com. Si tiene alguna pregunta acerca de sus derechos como voluntario en esta investigación, póngase en contacto con Janell Barker, administrador de investigación humana en 970491 1655. Le daremos una copia de este formulario de consentimiento para tenerlo con usted. Este formulario de consentimiento fue aprobado por la Junta de revisión institucional de CSU para la protección de sujetos humanos en investigación el 08 de agosto de 2012.

Su firma indica que ha leído y entiende esta información y que voluntariamente firmar este documento de consentimiento. Su firma también indica que ha recibido, en la fecha de firma, una copia de este documento que contiene 2 páginas.
Firma del participante
nombre impreso
Fecha

Firma del personal de investigación nombre impreso

Fecha 
Cuestionario para los rancheros

Fecha:

Comunidad del Rancho:

Región:__ Municipio:

GPS: UTM zona Este Norte

Miembros del hogar

Entrevista \#

\begin{tabular}{|c|c|c|c|c|c|c|c|c|c|c|c|}
\hline & 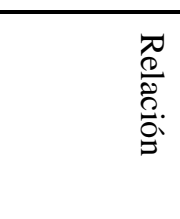 & 寻噌 & 熟 & 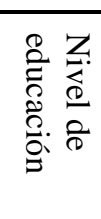 & 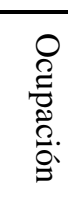 & 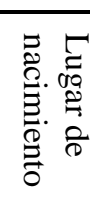 & 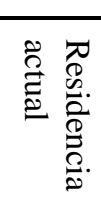 & 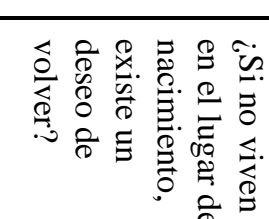 & 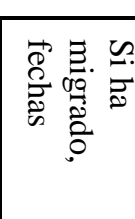 & 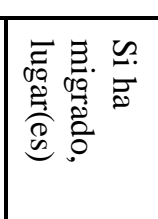 & 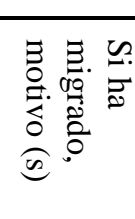 \\
\hline $\begin{array}{l}\text { Persona } 1 \\
\end{array}$ & $\begin{array}{l}\text { Cabeza de } \\
\text { la familia }\end{array}$ & & & & & & & & & & \\
\hline $\begin{array}{l}\text { Persona } 2 \\
\end{array}$ & & & & & & & & & & & \\
\hline Persona 3 & & & & & & & & & & & \\
\hline Persona 4 & & & & & & & & & & & \\
\hline $\begin{array}{l}\text { Persona } 5 \\
\end{array}$ & & & & & & & & & & & \\
\hline $\begin{array}{l}\text { Persona } 6 \\
\end{array}$ & & & & & & & & & & & \\
\hline
\end{tabular}


1. ¿Cuál es su principal fuente de agua para el consumo humano?

a. $\square$ Aguas superficiales (p. ej., arroyo)

b. $\square$ Pozo

2. ¿Cuál es la principal fuente de agua para sus animales?

a. $\square$ Aguas superficiales (p. ej., arroyo)

b. $\square$ Pozo

c. $\square$ Poza $\begin{array}{ll}\text { c. } & \square \text { Poza } \\ \text { d. } & \square \text { Otro }\end{array}$

d. $\square$ Tajo

e. $\square$ Otro

3. ¿Conserva el agua? $\square$ Sí, ¿cómo? $\square \mathrm{No}$

4. ¿Posee una concesión de CONAGUA para cualquier uso del agua (p. ej., pozo)?

5. ¿Ha tenido que cambiar la fuente de dónde saca el agua en los últimos 10 años porque no tiene agua?

6. ¿Cree que el tiempo se ha vuelto más impredecible en los últimos 10 años?

๑ Sí ¿por qué?

$\square$ No

7. ¿Cuál diría que es la principal amenaza ambiental a la que se enfrenta? (p. ej., escasez de agua, inundaciones)

8. ¿Durante la última sequía, cuáles de las siguientes acciones hizo para disminuir los efectos negativos?
a. $\square$ Encerró a sus animales en un corral
b. $\square$ Cambió de vacas a cabras
g. $\square$ Migro
c. $\square$ Plantó más alimento para sus animales
h. $\square$ Obtuvo trabajos PET
d. $\square$ Almacenó alimentación
e. $\square$ Produjo más para vender
f. $\square$ Plantó alimentos para uso personal
i. $\square$ Obtuvo otro trabajar fuera del campo
j. $\quad \square$ Trabajó con otras familias para compartir recursos
k. $\square$ Nada
1. $\square$ Otro

9. ¿Están actualmente haciendo cualquiera de las siguientes actividades para planear una severa sequía en el futuro?
a. $\square$ Plan para migrar
e. $\square$ Invertir en educación
b. $\square$ Reservas de agua
f. $\square$ Colaborar más estrechamente con personas de la comunidad
c. $\square$ Conservar el agua
g. $\square$ Nada
d. $\square$ Variar - diversificar sus ingresos
h. $\square$ Otro 
Cont'd Household survey, Spanish

1. ¿Usted tiene un número de teléfono o dirección de alguien en otro lugar que podría contactar ahora mismo si necesitará migrar? $\square$ Sí $\quad \square$ No

2. ¿Cree que podría encontrar un compañero de viaje si usted necesitará migrar ahora?

$\square$ Sí $\quad \square$ No

3. ¿Es miembro de alguna organización (por ejemplo, COTAS Comité Técnico de Aguas Subterráneas, Consejo escolar, otros)? $\square$ Sí, ¿de cuál? $\square \mathrm{No}$

4. ¿Obtiene información sobre las sequías? a. $\square$ Sí Señales del medio ambiente (p. ej., lluvias anteriores, comportamiento de los animales) por favor explique b. $\square$ Sí Familia

c. $\square$ Sí Otros rancheros

d. $\square$ Sí Radio

e. $\square$ Sí TV

f. $\square$ Sí Otra

g. $\square$ No

5. ¿Quién piensa que tiene la mayor responsabilidad de ayudar a su familia en tiempos de sequía?
a. $\square$ Yo
b. $\square$ Mi comunidad
c. $\square$ El gobierno ¿quién exactamente?
d. $\square$ ONG, ¿cuál?
e. $\square$ Otros 
Por favor, indique su ingreso u otros recursos usados cada mes para vivir poniendo monedas en los vasos para representar la cantidad. Me doy cuenta de que esto puede ser una pregunta personal, pero no estoy interesado en la cantidad de dinero que usted gana, sólo el grado de importancia que estas actividades representan para usted.

Por ejemplo, si la mayoría de su sus ingresos los obtiene con la cría de ganado y su cónyuge vende productos en el mercado, y su hija que vive en el extranjero y le envía un poco de dinero cada mes, tal vez le pondría 6 monedas en la taza que dice "ganadería," 3 monedas en la taza que dice "venta de productos" y 1 moneda en la taza para "Mi familia me manda dinero."

\begin{tabular}{|c|l|l|}
\hline A & Ganadería & \\
\hline B & PET & \\
\hline C & Otro trabajo & \\
\hline D & Venta de productos & \\
\hline E & Empresa familiar (restaurante, artesanías, etc.). & \\
\hline F & Mi familia me manda dinero & \\
\hline G & Ayuda del gobierno & \\
\hline H & Pensión & \\
\hline I & Ahorro & \\
\hline J & Otros & \\
\hline & TOTAL & 10 monedas \\
\hline
\end{tabular}

2. ¿Cómo espera pagar los daños que ocasionará la próxima sequía?

$$
\text { a. } \square \text { Ahorros }
$$

b. $\square$ Ayuda del gobierno ¿Qué organismo?

c. $\square$ Otro

3. ¿Tiene seguro para su tierra?

$\square$ Sí, ¿con quién?

4. ¿Tiene seguro para sus animales? $\square$ Sí, ¿con quién?

5. ¿Tiene seguro de desastres naturales? ฉ Sí, ¿con quién?

6. Si no tiene seguro, ¿qué le haría tener ganas o necesidad de un seguro en el futuro?

7. ¿Tiene acceso a créditos o préstamos? $\square$ Sí, ¿icon quién? $\square$ No, ¿por qué no?

$\square$ No, ¿por qué no?

$\square$ No, ¿por qué no?
8. ¿Tiene cualquier concesión o contrato con la CFE?

$$
\square \text { Sí }
$$

$\square$ No

$\square$ No 
Cont'd Household survey, Spanish

1. ¿Tiene título de tierra de su propiedad?

$\square$ No

2. ¿Cuántas hectáreas tiene?

a. $\square 0$

b. $\square 1-10$

c. $11-20$

d. $\square$ más de 20

5. ¿Cuántas mulas tiene?

a. $\square 0$

b. $1-5$

c. $\square$ 6-10

d. $\square$ más de 10

3. ¿Cuántas vacas tiene?

a. $\square 0$

b. $\square 1-5$

c. $\square$ 6-10

d. $\square$ más de 10

6. ¿Cuántos caballos tiene?

a. $\square 0$

b. $\square$ 1-5

c. $\square$ 6-10

d. $\square$ más de 10

4. ¿Cuántas cabras tiene?

a. $\square 0$

b. $\square 1-5$

c. $\square$ 6-10

d. $\square$ más de 10

8. ¿Normalmente cultiva su propia comida para comer, o compra su comida?

a. $\square$ Cultivo mis alimentos

7. ¿Cuántos pollos tiene?

a. $\square 0$

b. $\square$ 1-5

c. $\square$ 6-10

d. $\square$ más de 10

b. $\square$ Compro mis alimentos

9. ¿Tiene alguna forma de almacenar agua para el futuro? (¿funciona? y ¿tiene agua?)
a. $\square$ Bordo
b. $\square$ Presa
c. $\square$ Otra
d. $\square$ No

10. ¿Qué tan lejos, en horas, tiene que viajar al mercado más cercano? 
Cont'd Household survey, Spanish

1. ¿Tiene un certificado de nacimiento?

$\square$ Sí

$\square$ No

2. ¿Tiene un pasaporte?

$\square$ Sí

$\square$ No

3. ¿Tiene seguro de salud?

4. ¿Alguien en su familia tiene una discapacidad o enfermedad crónica?

5. ¿Por qué razón dejaría usted su comunidad?
a. $\square$ Desastres naturales
b. $\square$ Trabajo
c. $\square$ Escuela
d. $\square$ Calidad de vida
e. $\square$ Razones de salud
f. $\square$ Otro
g. $\square$ No la dejaría nunca, bajo ninguna circunstancia

6. ¿Ha recibido capacitaciones de profesionales?

a. $\square$ Conservación de agua, ¿de quién?

b. Desarrollo económico, ¿de quién?

c. $\square$ Meteorología, ¿de quién?

d. Otro, ¿quién?

e. $\square$ Ninguna

7. ¿En qué áreas desearía recibir capacitaciones?

\section{¡Gracias por su participación!}


In addition to the surveys, 11 ranchero groups (some individual, some groups of neighbors) were selected for one-hour in-depth interviews on their drought experiences in Baja California Sur. A total of 18 rancheros participated in the conversations, five women and 13 men ranging in age from 29-96 years. The interviews were unstructured or semi-structured in that questions were not asked verbatim to each respondent. Interviewers were trained to guide the conversation towards past droughts for the purposes of documenting specific drought years in the life history of the respondent, how they discerned the drought as abnormal, what actions they took to cope with the drought, and who they received help from, if any. The questions were entirely open-ended and respondents talked about their memories of droughts in any order they chose. Interviews typically lasted anywhere from thirty minutes to an hour. The interviews were audio-recorded, with permission, and two bilingual speakers transcribed the recordings in both English and Spanish.

3 Qualitative Comparative Analysis (QCA)

QCA relies on Boolean algebra to assess the relationship between a specific trait configuration and an outcome (Ragin 1987; Ragin 2006). In other words, QCA allows the establishment of necessary and sufficient conditions for an outcome to occur. A trait (or configuration of traits) is necessary if it must be present for a certain outcome to occur. A trait (or configuration of traits) is sufficient if, by itself, it can produce a certain outcome (Ragin 1987). A trait (or configuration of traits) is both necessary and sufficient if it is the only cause to the outcome. Although QCA cannot be used to make cause-effect inferences, such as whether certain household traits lead to specific drought strategies or vice versa, it helps us discover factors that are sufficient or necessary for drought response. It is used to identify relevant conditions and membership in those conditions (Schneider and Wagemann 2010).

Consistency is the degree to which the relation between a causal conditions and outcomes are necessary or sufficient. Consistency of 0 or 1 actually indicates that the casual combination always leads to a non-outcome or outcome respectively. Consistency of 0.5 indicates that in $50 \%$ of the cases the causal conditions lead to the outcome and the remaining $50 \%$ of the cases to a non-outcome. Regarding the raw coverage of trait combination, the lower a coverage score, the less empirically relevant a causal trait combination: the causal configuration explains fewer cases in which the outcome occurred. Additionally, we employed a reliability metrics proposed in Baggio et al. (2016). These extra steps include running two additional QCA: one in which all missing values are set to 0 (indicating absence of a trait), and one in which all missing value as set to 1 (indicating presence of the trait. Reliability of QCA solution set and metrics allows us to assess the reliability boundaries of the QCA without missing data. Table 2 shows descriptive statistics of the presence and absence of those households which did not adopt any of the selected drought strategies. Table 
3 shows the fractions of times a household trait is present in a consistent solution leading to presence and absence of each adaptation

strategy.

Table 4 shows the Solution Sets. We conducted the following process to calculate reliability Baggio et al. (2016):

1. We performed QCA on the 163 complete cases

2. We performed QCA on the dataset assuming missing data (skipped questions) = absent (setting values to 0)

3. We performed QCA on the dataset assuming missing data = present (setting values to 1)

4. We calculated reliability of coverage $\mathrm{R}(\mathrm{Cov})$ as 1 - standard deviation of coverage scores of the 3 QCA analysis $($ Complete, Missing = 0 , Missing = 1)

5. We calculated reliability of consistency $\mathrm{R}(\mathrm{Cons})$ as 1 - standard deviation of consistency scores of the 3 QCA analysis $($ Complete, Missing = 0 , Missing = 1)

6. We calculated the solution reliability as the percentage the set was reported in the solution set: $R(\operatorname{Sol})=N_{\text {set }} / 3$ where 3 is the number of QCA analysis performed (Complete, Missing = 0, Missing = 1).

Truth tables show all possible trait configurations for each outcome. The Truth Tables in Table 5 show the frequency of cases matching a specific configuration, relative to the maximum number of times it is present in Complete, Missing $=0$, and Missing $=1$

cases. Finally, we assess trait presence in adaptation vis-à-vis no adaptation sets for all configurations that lead to a specific result (adaptation or no adaptation) in more than $50 \%$ of cases (Table 6).

Table 1. Household traits and definitions

\begin{tabular}{|l|l|l|}
\hline Symbol (label) & ID & Description \\
\hline J (rch) & Head of household occupation & Head of household reported "rancher" as their occupation. \\
\hline E (region) & Region & $\begin{array}{l}\text { The household lived in the La Paz municipality, which has } \\
\text { better maintained access roads and more urban water } \\
\text { infrastructure and delivery systems. }\end{array}$ \\
\hline W (wat) & Female education & $\begin{array}{l}\text { Any female in the household reported any secondary or higher } \\
\text { schooling. }\end{array}$ \\
\hline C (clim) & $\begin{array}{l}\text { Access to surface water for } \\
\text { human consumption }\end{array}$ & $\begin{array}{l}\text { The household reported accessing surface water for human } \\
\text { consumption. }\end{array}$ \\
\hline S (soc) & Climate sensitivity & $\begin{array}{l}\text { The respondent responded positively to the question "Have you } \\
\text { perceived that the weather has been unpredictable in the last } \\
\text { ten years?" }\end{array}$ \\
\hline F (fin) & Social capital & $\begin{array}{l}\text { The respondent responded positively to the question "Are you } \\
\text { a member of a community organization?" }\end{array}$ \\
\hline T (tit) & Financial diversity & $\begin{array}{l}\text { The household reported more than one source of income } \\
\text { including business income, remittances, government aid, } \\
\text { pensions. }\end{array}$ \\
\hline L (lvs) & Land ownership & $\begin{array}{l}\text { Household reported that they own any type of farm animals } \\
\text { including chickens, cows, mules, horses or goats. }\end{array}$ \\
\hline
\end{tabular}


Table 2. Household traits presence and absence of non-adopting households

\begin{tabular}{|c|c|c|c|c|c|c|}
\hline $\begin{array}{l}\text { Household Traits } \\
\text { (symbols in } \\
\text { parenthesis) }\end{array}$ & Values & $\begin{array}{c}\text { No } \\
\text { Strategy } \\
\text { Taken } \\
n=22\end{array}$ & $\begin{array}{c}\text { No Environmental } \\
\text { Migration } \\
n=137\end{array}$ & $\begin{array}{c}\text { No Household } \\
\text { Migration } \\
n=116\end{array}$ & $\begin{array}{c}\text { No Change } \\
\text { in Farming } \\
\text { Practices } \\
n=72\end{array}$ & $\begin{array}{c}\text { No Off- } \\
\text { Farm Work } \\
\text { Acquired } \\
\mathrm{n}=68\end{array}$ \\
\hline \multirow{3}{*}{$\begin{array}{l}\text { Lives in the region } \\
\text { that has better } \\
\text { urban access (reg) }\end{array}$} & Absence & $1(5 \%)$ & $30(22 \%)$ & $20(17 \%)$ & $2(3 \%)$ & $8(12 \%)$ \\
\hline & Presence & $21(96 \%)$ & $106(77 \%)$ & $95(82 \%)$ & $70(97 \%)$ & $60(88 \%)$ \\
\hline & Missing & $0(0 \%)$ & $1(1 \%)$ & $1(1 \%)$ & $0(0 \%)$ & $0(0 \%)$ \\
\hline \multirow{3}{*}{$\begin{array}{l}\text { Any female } \\
\text { household member } \\
\text { graduated from } \\
\text { primary school } \\
\text { (edu) }\end{array}$} & Absence & $12(55 \%)$ & $69(50 \%)$ & $64(55 \%)$ & $42(58 \%)$ & $46(49 \%)$ \\
\hline & Presence & $9(41 \%)$ & $65(47 \%)$ & $49(42 \%)$ & $28(39 \%)$ & $33(49 \%)$ \\
\hline & Missing & $1(5 \%)$ & $3(2 \%)$ & $3(3 \%)$ & $2(3 \%)$ & $2(3 \%)$ \\
\hline \multirow{3}{*}{$\begin{array}{l}\text { Head of household } \\
\text { is a rancher (rch) }\end{array}$} & Absence & $19(86 \%)$ & $108(79 \%)$ & $88(76 \%)$ & $60(83 \%)$ & $53(78 \%)$ \\
\hline & Presence & $3(14 \%)$ & $29(21 \%)$ & $28(24 \%)$ & $12(17 \%)$ & $15(22 \%)$ \\
\hline & Missing & $0(0 \%)$ & $0(0 \%)$ & $0(0 \%)$ & $\begin{array}{ll}0 & (0 \%)\end{array}$ & $\begin{array}{ll}0 & (0 \%)\end{array}$ \\
\hline \multirow{3}{*}{$\begin{array}{l}\text { Relies on surface } \\
\text { water for human } \\
\text { consumption (wat) }\end{array}$} & Absence & $19(86 \%)$ & $114(83 \%)$ & $99(85 \%)$ & $61(85 \%)$ & $59(87 \%)$ \\
\hline & Presence & $3(14 \%)$ & $23(17 \%)$ & $17(15 \%)$ & $11(15 \%)$ & $9(13 \%)$ \\
\hline & Missing & $0(0 \%)$ & $0(0 \%)$ & $0 \quad(0 \%)$ & $0 \quad(0 \%)$ & $0 \quad(0 \%)$ \\
\hline \multirow{3}{*}{$\begin{array}{l}\text { Reports } \\
\text { unpredictable } \\
\text { weather in the last } \\
10 \text { years }(\mathrm{clm})\end{array}$} & Absence & $0(0 \%)$ & $114(83 \%)$ & $8(7 \%)$ & $2(3 \%)$ & $3(4 \%)$ \\
\hline & Presence & $22(100 \%)$ & $23(17 \%)$ & $106(91 \%)$ & $70(98 \%)$ & $65(96 \%)$ \\
\hline & Missing & $0(0 \%)$ & $2(1.5 \%)$ & $2(2 \%)$ & $0 \quad(0 \%)$ & $0 \quad(0 \%)$ \\
\hline \multirow{3}{*}{$\begin{array}{l}\text { Belongs to an } \\
\text { organization (soc) }\end{array}$} & Absence & $9(41 \%)$ & $49(36 \%)$ & $60(52 \%)$ & $36(50 \%)$ & $31(46 \%)$ \\
\hline & Presence & $13(59 \%)$ & $87(64 \%)$ & $55(47 \%)$ & $35(49 \%)$ & $35(52 \%)$ \\
\hline & Missing & $0(0 \%)$ & $1(1 \%)$ & $1 \quad(1 \%)$ & $1 \quad(1 \%)$ & $2(3 \%)$ \\
\hline \multirow{3}{*}{$\begin{array}{l}\text { Reports more than } \\
\text { one income stream } \\
\text { (fin) }\end{array}$} & Absence & $13(59 \%)$ & $66(48 \%)$ & $43(37 \%)$ & $35(49 \%)$ & $22(32 \%)$ \\
\hline & Presence & $9(41 \%)$ & $68(68 \%)$ & $73(63 \%)$ & $37(51 \%)$ & $45(66 \%)$ \\
\hline & Missing & $0(0 \%)$ & $3(2 \%)$ & $\begin{array}{ll}0 & (0 \%)\end{array}$ & $\begin{array}{ll}0 & (0 \%)\end{array}$ & $1 \quad(2 \%)$ \\
\hline \multirow{3}{*}{ Holds land title (tit) } & Absence & $12(55 \%)$ & $52(38 \%)$ & $43(37 \%)$ & $27(38 \%)$ & $28(41 \%)$ \\
\hline & Presence & $10(46 \%)$ & $80(58 \%)$ & $69(60 \%)$ & $42(58 \%)$ & $39(57 \%)$ \\
\hline & Missing & $0(0 \%)$ & $5(4 \%)$ & $4(3 \%)$ & $3(4 \%)$ & $1 \quad(2 \%)$ \\
\hline \multirow{3}{*}{$\begin{array}{l}\text { Owns livestock } \\
\text { (lvs) }\end{array}$} & Absence & $5(23 \%)$ & $12(9 \%)$ & $10(9 \%)$ & $12(17 \%)$ & $7(10 \%)$ \\
\hline & Presence & $17(77 \%)$ & $122(89 \%)$ & $105(91 \%)$ & $60(83 \%)$ & $60(88 \%)$ \\
\hline & Missing & $0(0 \%)$ & $3(2 \%)$ & $11 \%)$ & $0(0 \%)$ & $\begin{array}{ll}1(2 \%) \\
\end{array}$ \\
\hline
\end{tabular}

*Note: Totals may not sum to $100 \%$ because of rounding in the percentage calculations. 
Table 3. Fraction of times a trait is present in a solution leading to presence and to absence for cases $>0.5$ consistency $($ complete, $\operatorname{missing}=0$, and missing $=1)$ See Table 1 for label definitions

\begin{tabular}{|c|c|c|c|c|c|c|c|c|c|c|c|}
\hline \multirow[b]{2}{*}{ QCA Data } & \multirow[b]{2}{*}{ Trait } & \multicolumn{2}{|l|}{ Any strategy } & \multicolumn{2}{|l|}{ Farm } & \multicolumn{2}{|l|}{ Off-farm } & \multicolumn{2}{|c|}{ Enviro Migration } & \multicolumn{2}{|c|}{$\begin{array}{l}\text { Any Household } \\
\text { Migration }\end{array}$} \\
\hline & & Absent & Present & Absent & Present & Absent & Present & Absent & Present & Absent & Present \\
\hline \multirow[t]{9}{*}{ Complete } & $\mathrm{J}$ & 0.08 & 0.91 & 0.34 & 0.66 & 0.40 & 0.60 & 0.80 & 0.20 & 0.73 & 0.27 \\
\hline & $\mathrm{R}$ & 0.18 & 0.82 & 0.57 & 0.43 & 0.52 & 0.48 & 0.89 & 0.11 & 0.79 & 0.21 \\
\hline & $\mathrm{E}$ & 0.12 & 0.88 & 0.37 & 0.64 & 0.42 & 0.58 & 0.80 & 0.20 & 0.59 & 0.41 \\
\hline & $\mathrm{W}$ & 0.12 & 0.88 & 0.44 & 0.56 & 0.32 & 0.68 & 0.84 & 0.16 & 0.64 & 0.36 \\
\hline & $\mathrm{C}$ & 0.16 & 0.84 & 0.47 & 0.53 & 0.46 & 0.54 & 0.84 & 0.16 & 0.71 & 0.29 \\
\hline & S & 0.17 & 0.83 & 0.44 & 0.56 & 0.46 & 0.55 & 0.84 & 0.16 & 0.67 & 0.33 \\
\hline & $\mathrm{F}$ & 0.10 & 0.91 & 0.36 & 0.64 & 0.46 & 0.54 & 0.83 & 0.17 & 0.69 & 0.31 \\
\hline & $\mathrm{T}$ & 0.11 & 0.89 & 0.43 & 0.57 & 0.41 & 0.59 & 0.82 & 0.18 & 0.70 & 0.31 \\
\hline & $\mathrm{L}$ & 0.12 & 0.88 & 0.40 & 0.60 & 0.43 & 0.57 & 0.83 & 0.17 & 0.71 & 0.30 \\
\hline \multirow[t]{9}{*}{ Missing $=0$} & $\mathrm{~J}$ & 0.08 & 0.92 & 0.33 & 0.67 & 0.42 & 0.58 & 0.81 & 0.19 & 0.74 & 0.26 \\
\hline & $\mathrm{R}$ & 0.18 & 0.82 & 0.58 & 0.42 & 0.50 & 0.50 & 0.89 & 0.11 & 0.79 & 0.21 \\
\hline & $\mathrm{E}$ & 0.11 & 0.89 & 0.35 & 0.65 & 0.41 & 0.59 & 0.81 & 0.19 & 0.60 & 0.40 \\
\hline & $\mathrm{W}$ & 0.11 & 0.89 & 0.41 & 0.59 & 0.33 & 0.67 & 0.85 & 0.15 & 0.63 & 0.37 \\
\hline & $\mathrm{C}$ & 0.15 & 0.85 & 0.46 & 0.54 & 0.44 & 0.56 & 0.85 & 0.15 & 0.72 & 0.28 \\
\hline & $\mathrm{S}$ & 0.16 & 0.84 & 0.43 & 0.57 & 0.45 & 0.55 & 0.86 & 0.15 & 0.66 & 0.34 \\
\hline & $\mathrm{F}$ & 0.09 & 0.91 & 0.36 & 0.64 & 0.44 & 0.56 & 0.85 & 0.15 & 0.70 & 0.31 \\
\hline & $\mathrm{T}$ & 0.10 & 0.90 & 0.43 & 0.57 & 0.39 & 0.61 & 0.83 & 0.17 & 0.70 & 0.30 \\
\hline & $\mathrm{L}$ & 0.11 & 0.89 & 0.40 & 0.60 & 0.41 & 0.59 & 0.84 & 0.16 & 0.71 & 0.29 \\
\hline \multirow[t]{9}{*}{ Missing $=1$} & $\mathrm{~J}$ & 0.08 & 0.92 & 0.33 & 0.67 & 0.42 & 0.58 & 0.81 & 0.19 & 0.74 & 0.26 \\
\hline & $\mathrm{R}$ & 0.18 & 0.82 & 0.58 & 0.42 & 0.50 & 0.50 & 0.89 & 0.11 & 0.79 & 0.21 \\
\hline & E & 0.11 & 0.89 & 0.35 & 0.65 & 0.41 & 0.59 & 0.81 & 0.19 & 0.60 & 0.40 \\
\hline & $\mathrm{W}$ & 0.11 & 0.89 & 0.41 & 0.59 & 0.33 & 0.67 & 0.85 & 0.15 & 0.63 & 0.37 \\
\hline & $\mathrm{C}$ & 0.15 & 0.85 & 0.47 & 0.53 & 0.44 & 0.56 & 0.85 & 0.15 & 0.72 & 0.28 \\
\hline & S & 0.16 & 0.84 & 0.44 & 0.56 & 0.44 & 0.56 & 0.85 & 0.15 & 0.67 & 0.33 \\
\hline & $\mathrm{F}$ & 0.09 & 0.91 & 0.36 & 0.64 & 0.44 & 0.56 & 0.85 & 0.16 & 0.70 & 0.30 \\
\hline & $\mathrm{T}$ & 0.10 & 0.90 & 0.42 & 0.58 & 0.40 & 0.60 & 0.83 & 0.18 & 0.70 & 0.30 \\
\hline & $\mathrm{L}$ & 0.12 & 0.88 & 0.40 & 0.60 & 0.41 & 0.59 & 0.84 & 0.16 & 0.71 & 0.29 \\
\hline
\end{tabular}

Note: $n=$ number of cases matching a specific configuration, Consistency $=$ sufficiency consistency score. $0=$ absent, $1=$ present . 
Table 4. QCA Solution Sets Tables

QCA minimized solution for all cases per activity. Solution Sets are for Presence and Absence

Cons $=$ consistency, $\mathrm{Cov}=$ coverage, Sol $=$ solution

Set leading to
Strategy Minimized Solution Set type
Complete Missing $=1 \quad$ Missing $=0 \quad$ Reliability

Cons Cov Cons Cov Cons Cov Cons Cov Sol

Present

\author{
All
}

$\begin{array}{ll}\text { CTL } & \text { jw } \\ \text { JECFTL } & \\ \text { ECL } & \text { jws } \\ \text { ECFL } & w\end{array}$

ECSFTL

RCL

JRCFL $\quad \mathrm{w}$

ESTL jwf

ECSFL jr

RCL $\quad$ jft

RCFL jet

REC jtl

JRCL et

JRCSFTL

CT jewfl

ESTL jr

CFL jrwt

CSFL jrw

ESTL jr

CSFL jew

FTL rews

CST jewfl

RWCF jest

RECT jsfl

JEWCTL rs

JRL esft

JRSFTL e

WCFTL jre

EFL jrst

JWCSTL ref

JEWFL rest

JEWCSL $\quad \mathrm{rft}$

E

$$
\text { jrcsft }
$$

\begin{tabular}{|c|c|c|c|c|c|c|c|c|}
\hline 0.00 & 0.00 & 0.93 & 0.11 & 0.00 & 0.00 & 0.60 & 0.60 & 0.33 \\
\hline 0.00 & 0.00 & 0.00 & 0.00 & 0.90 & 0.10 & 0.61 & 0.60 & 0.33 \\
\hline 0.95 & 0.14 & 0.95 & 0.04 & 0.95 & 0.11 & 0.53 & 0.53 & 1.00 \\
\hline 1.00 & 0.13 & 1.00 & 0.18 & 1.00 & 0.01 & 0.51 & 0.54 & 1.00 \\
\hline 0.91 & 0.15 & 0.91 & 0.14 & 0.91 & 0.04 & 0.56 & 0.58 & 1.00 \\
\hline 0.85 & 0.17 & 0.85 & 0.14 & 0.86 & 0.04 & 0.59 & 0.62 & 1.00 \\
\hline 0.93 & 0.11 & 0.93 & 0.15 & 0.93 & 0.14 & 0.56 & 0.56 & 1.00 \\
\hline 0.88 & 0.06 & 0.00 & 0.00 & 0.00 & 0.00 & 0.98 & 0.61 & 0.33 \\
\hline 0.86 & 0.05 & 0.89 & 0.05 & 0.00 & 0.00 & 0.61 & 0.54 & 0.67 \\
\hline 0.43 & 0.02 & 0.43 & 0.06 & 0.43 & 0.01 & 0.78 & 0.79 & 1.00 \\
\hline 0.87 & 0.10 & 0.87 & 0.02 & 0.88 & 0.04 & 0.55 & 0.56 & 1.00 \\
\hline 0.40 & 0.02 & 0.40 & 0.09 & 0.40 & 0.02 & 0.80 & 0.81 & 1.00 \\
\hline 0.86 & 0.05 & 0.86 & 0.01 & 0.86 & 0.04 & 0.55 & 0.55 & 1.00 \\
\hline 0.71 & 0.04 & 0.75 & 0.04 & 0.71 & 0.02 & 0.62 & 0.62 & 1.00 \\
\hline 0.00 & 0.00 & 0.00 & 0.00 & 0.75 & 0.17 & 0.68 & 0.66 & 0.33 \\
\hline 0.00 & 0.00 & 0.00 & 0.00 & 1.00 & 0.07 & 0.56 & 0.55 & 0.33 \\
\hline 0.00 & 0.00 & 0.00 & 0.00 & 0.86 & 0.04 & 0.62 & 0.62 & 0.33 \\
\hline 0.00 & 0.00 & 0.00 & 0.00 & 0.83 & 0.04 & 0.63 & 0.63 & 0.33 \\
\hline 0.00 & 0.00 & 1.00 & 0.03 & 0.00 & 0.00 & 0.56 & 0.56 & 0.33 \\
\hline 0.88 & 0.11 & 0.88 & 0.10 & 0.00 & 0.00 & 0.63 & 0.56 & 0.67 \\
\hline 1.00 & 0.02 & 1.00 & 0.01 & 1.00 & 0.01 & 0.46 & 0.46 & 1.00 \\
\hline 1.00 & 0.02 & 1.00 & 0.01 & 1.00 & 0.01 & 0.46 & 0.46 & 1.00 \\
\hline 0.75 & 0.02 & 0.75 & 0.02 & 0.75 & 0.04 & 0.60 & 0.60 & 1.00 \\
\hline 1.00 & 0.02 & 1.00 & 0.01 & 1.00 & 0.01 & 0.46 & 0.46 & 1.00 \\
\hline 1.00 & 0.02 & 1.00 & 0.01 & 1.00 & 0.02 & 0.46 & 0.46 & 1.00 \\
\hline 1.00 & 0.02 & 1.00 & 0.01 & 1.00 & 0.01 & 0.46 & 0.46 & 1.00 \\
\hline 1.00 & 0.04 & 1.00 & 0.04 & 1.00 & 0.01 & 0.47 & 0.47 & 1.00 \\
\hline 1.00 & 0.02 & 1.00 & 0.17 & 0.00 & 0.00 & 0.57 & 0.48 & 0.67 \\
\hline 0.00 & 0.00 & 0.00 & 0.00 & 1.00 & 0.14 & 0.56 & 0.55 & 0.33 \\
\hline 1.00 & 0.01 & 1.00 & 0.01 & 1.00 & 0.01 & 0.46 & 0.46 & 1.00 \\
\hline 1.00 & 0.01 & 1.00 & 0.01 & 1.00 & 0.01 & 0.46 & 0.46 & 1.00 \\
\hline 1.00 & 0.01 & 1.00 & 0.01 & 1.00 & 0.01 & 0.46 & 0.46 & 1.00 \\
\hline 0.00 & 0.00 & 0.00 & 0.00 & 1.00 & 0.13 & 0.56 & 0.55 & 0.33 \\
\hline
\end{tabular}


Cont'd Table 4. QCA Solution Sets Tables

Set leading to

Present
Strategy

type

Trait present
Complete $\quad$ Missing=1

Missing $=0$

Cons Cov Cov Farm

\begin{tabular}{|c|c|c|c|c|c|c|c|c|c|c|}
\hline ECL & jws & 0.18 & 0.79 & 0.02 & 0.76 & 0.17 & 0.75 & 0.63 & 0.64 & 1.00 \\
\hline ECFL & w & 0.16 & 0.77 & 0.03 & 0.74 & 0.14 & 0.72 & 0.64 & 0.65 & 1.00 \\
\hline ECSFTL & & 0.19 & 0.76 & 0.12 & 0.78 & 0.18 & 0.76 & 0.66 & 0.67 & 1.00 \\
\hline RCL & ews & 0.13 & 0.42 & 0.01 & 0.41 & 0.12 & 0.39 & 0.81 & 0.81 & 1.00 \\
\hline JRCFL & $\mathrm{w}$ & 0.07 & 0.40 & 0.00 & 0.40 & 0.07 & 0.40 & 0.80 & 0.80 & 1.00 \\
\hline ESTL & jwf & 0.04 & 0.38 & 0.00 & 0.00 & 0.00 & 0.00 & 0.83 & 0.84 & 0.67 \\
\hline ECSFL & $\mathrm{jr}$ & 0.07 & 0.86 & 0.02 & 0.89 & 0.00 & 0.00 & 0.53 & 0.54 & 0.67 \\
\hline RCL & jft & 0.00 & 0.00 & 0.00 & 0.00 & 0.00 & 0.00 & 1.00 & 1.00 & 1.00 \\
\hline RCFL & jet & 0.11 & 0.60 & 0.01 & 0.60 & 0.10 & 0.53 & 0.71 & 0.71 & 1.00 \\
\hline REC & jtl & 0.00 & 0.00 & 0.00 & 0.00 & 0.00 & 0.00 & 1.00 & 1.00 & 1.00 \\
\hline JRCL & et & 0.06 & 0.71 & 0.01 & 0.71 & 0.06 & 0.71 & 0.63 & 0.63 & 1.00 \\
\hline JRCSFTL & & 0.02 & 0.29 & 0.00 & 0.38 & 0.02 & 0.29 & 0.83 & 0.82 & 1.00 \\
\hline CSFL & jew & 0.13 & 0.69 & 0.06 & 0.65 & 0.00 & 0.00 & 0.64 & 0.67 & 0.67 \\
\hline CTL & jw & 0.00 & 0.00 & 0.01 & 0.59 & 0.00 & 0.00 & 0.74 & 0.74 & 0.67 \\
\hline CFTL & jre & 0.00 & 0.00 & 0.02 & 1.00 & 0.00 & 0.00 & 0.56 & 0.56 & 0.33 \\
\hline $\mathrm{CT}$ & jewfl & 0.00 & 0.00 & 0.00 & 0.00 & 0.01 & 0.25 & 0.89 & 1.00 & 0.33 \\
\hline JECFTL & & 0.00 & 0.00 & 0.00 & 0.00 & 0.08 & 0.70 & 0.69 & 0.97 & 0.33 \\
\hline CFL & jrwt & 0.00 & 0.00 & 0.00 & 0.00 & 0.07 & 0.86 & 0.62 & 0.97 & 0.33 \\
\hline CSFL & jrw & 0.00 & 0.00 & 0.00 & 0.00 & 0.06 & 0.83 & 0.63 & 0.97 & 0.33 \\
\hline FTL & rews & 0.02 & 1.00 & 0.02 & 1.00 & 0.02 & 1.00 & 0.46 & 0.46 & 1.00 \\
\hline CST & jewfl & 0.00 & 0.00 & 0.00 & 0.00 & 0.00 & 0.00 & 1.00 & 1.00 & 0.67 \\
\hline RWCF & jest & 0.01 & 0.25 & 0.00 & 0.25 & 0.01 & 0.25 & 0.87 & 0.87 & 1.00 \\
\hline RECT & jsfl & 0.00 & 0.00 & 0.00 & 0.00 & 0.00 & 0.00 & 1.00 & 1.00 & 1.00 \\
\hline JEWCTL & rs & 0.02 & 1.00 & 0.02 & 1.00 & 0.02 & 1.00 & 0.46 & 0.46 & 1.00 \\
\hline JRL & esft & 0.02 & 1.00 & 0.01 & 1.00 & 0.02 & 1.00 & 0.46 & 0.46 & 1.00 \\
\hline JRSFTL & $\mathrm{e}$ & 0.04 & 0.60 & 0.01 & 0.60 & 0.03 & 0.60 & 0.68 & 0.69 & 1.00 \\
\hline WCFTL & jre & 0.02 & 1.00 & 0.00 & 0.00 & 0.00 & 0.00 & 0.55 & 0.56 & 0.33 \\
\hline ESTL & $\mathrm{jr}$ & 0.00 & 0.00 & 0.03 & 1.00 & 0.07 & 1.00 & 0.47 & 0.56 & 0.67 \\
\hline EFL & jrst & 0.00 & 0.00 & 0.00 & 0.00 & 0.06 & 1.00 & 0.56 & 0.97 & 0.33 \\
\hline EWCSF & jrt & 0.00 & 0.00 & 0.00 & 0.00 & 0.02 & 1.00 & 0.56 & 0.99 & 0.33 \\
\hline JEWFL & rest & 0.01 & 1.00 & 0.01 & 1.00 & 0.01 & 1.00 & 0.46 & 0.46 & 1.00 \\
\hline JEWCSL & $\mathrm{rft}$ & 0.01 & 1.00 & 0.01 & 1.00 & 0.01 & 1.00 & 0.46 & 0.46 & 1.00 \\
\hline $\mathrm{E}$ & jresft & 0.00 & 0.00 & 0.00 & 0.00 & 0.01 & 1.00 & 0.55 & 0.99 & 0.33 \\
\hline
\end{tabular}


Cont'd Table 4. QCA Solution Sets Tables

Set leading to
Strategy type

Off
farm
Trait present Trait absent
Minimized Solution Set

Complete Missing $=1 \quad$ Missing $=0 \quad$ Reliability

Cons Cov Cons Cov Cons Cov Cons Cov Sol

$\begin{array}{ll}\text { JWCSTL } & \text { ref } \\ \text { ECL } & \text { jws } \\ \text { ECFL } & \text { w }\end{array}$

ECSFTL

RCL ews

JRCFL

w

JECFTL

CTL jw

ESTL jwf

ECSFL jr

RCL $\quad j f t$

RCFL jet

REC jtl

JRCL et

JRCSFTL

CSFL jew

CSFL jew

ESTL jr

CFTL jre

ESTL jr

CFL jrwt

CSFL jrw

CT jewfl

FTL rews

CST jewfl

RWCF jest

RECT jsfl

JEWCTL rs

JRL esft

JRSFTL e

WCFTL jre

EFL jrst

EWCSF jrt

JEWFL rest

JEWCSL rft

E jresft $\begin{array}{lllllllll}0.01 & 1.00 & 0.01 & 1.00 & 0.01 & 1.00 & 0.46 & 0.46 & 1.00\end{array}$

$\begin{array}{lllllllll}0.13 & 0.58 & 0.14 & 0.62 & 0.13 & 0.60 & 0.74 & 0.74 & 1.00\end{array}$

$\begin{array}{lllllllll}0.13 & 0.65 & 0.14 & 0.68 & 0.13 & 0.67 & 0.71 & 0.71 & 1.00\end{array}$

$\begin{array}{lllllllll}0.16 & 0.62 & 0.15 & 0.61 & 0.14 & 0.62 & 0.74 & 0.75 & 1.00\end{array}$

$\begin{array}{lllllllll}0.18 & 0.58 & 0.17 & 0.59 & 0.18 & 0.61 & 0.77 & 0.78 & 1.00\end{array}$

$\begin{array}{lllllllll}0.07 & 0.40 & 0.07 & 0.40 & 0.07 & 0.40 & 0.82 & 0.82 & 1.00\end{array}$

$\begin{array}{lllllllll}0.00 & 0.00 & 0.00 & 0.00 & 0.08 & 0.70 & 0.69 & 0.97 & 0.33\end{array}$

$\begin{array}{lllllllll}0.00 & 0.00 & 0.04 & 1.00 & 0.00 & 0.00 & 0.56 & 0.56 & 0.33\end{array}$

$\begin{array}{lllllllll}0.07 & 0.75 & 0.00 & 0.00 & 0.00 & 0.00 & 0.66 & 0.67 & 0.33\end{array}$

$\begin{array}{lllllllll}0.05 & 0.57 & 0.07 & 0.67 & 0.00 & 0.00 & 0.67 & 0.68 & 0.67\end{array}$

$\begin{array}{lllllllll}0.02 & 0.29 & 0.02 & 0.29 & 0.02 & 0.29 & 0.86 & 0.86 & 1.00\end{array}$

$\begin{array}{lllllllll}0.08 & 0.47 & 0.08 & 0.47 & 0.10 & 0.53 & 0.78 & 0.79 & 1.00\end{array}$

$\begin{array}{lllllllll}0.01 & 0.20 & 0.01 & 0.20 & 0.01 & 0.20 & 0.90 & 0.90 & 1.00\end{array}$

$\begin{array}{lllllllll}0.06 & 0.71 & 0.05 & 0.71 & 0.05 & 0.71 & 0.64 & 0.64 & 1.00\end{array}$

$\begin{array}{lllllllll}0.04 & 0.43 & 0.03 & 0.38 & 0.03 & 0.43 & 0.79 & 0.80 & 1.00\end{array}$

$\begin{array}{lllllllll}0.07 & 0.38 & 0.08 & 0.41 & 0.00 & 0.00 & 0.80 & 0.81 & 0.67\end{array}$

$\begin{array}{lllllllll}0.00 & 0.00 & 0.05 & 0.71 & 0.00 & 0.00 & 0.69 & 0.69 & 0.33\end{array}$

$\begin{array}{lllllllll}0.00 & 0.00 & 0.19 & 0.67 & 0.00 & 0.00 & 0.71 & 0.71 & 0.33\end{array}$

$\begin{array}{lllllllll}0.00 & 0.00 & 0.00 & 0.00 & 0.00 & 0.00 & 1.00 & 1.00 & 0.33\end{array}$

$\begin{array}{lllllllll}0.00 & 0.00 & 0.00 & 0.00 & 0.05 & 0.83 & 0.63 & 0.98 & 0.33\end{array}$

$\begin{array}{lllllllll}0.00 & 0.00 & 0.00 & 0.00 & 0.05 & 0.71 & 0.69 & 0.98 & 0.33\end{array}$

$\begin{array}{lllllllll}0.00 & 0.00 & 0.00 & 0.00 & 0.04 & 0.67 & 0.71 & 0.98 & 0.33\end{array}$

$\begin{array}{lllllllll}0.00 & 0.00 & 0.00 & 0.00 & 0.03 & 0.75 & 0.67 & 0.99 & 0.33\end{array}$

$\begin{array}{lllllllll}0.02 & 1.00 & 0.02 & 1.00 & 0.02 & 1.00 & 0.46 & 0.46 & 1.00\end{array}$

$\begin{array}{lllllllll}0.02 & 1.00 & 0.02 & 1.00 & 0.00 & 0.00 & 0.46 & 0.46 & 0.67\end{array}$

$\begin{array}{lllllllll}0.02 & 0.50 & 0.02 & 0.50 & 0.02 & 0.50 & 0.74 & 0.74 & 1.00\end{array}$

$\begin{array}{lllllllll}0.02 & 1.00 & 0.02 & 1.00 & 0.02 & 1.00 & 0.46 & 0.46 & 1.00\end{array}$

$\begin{array}{lllllllll}0.01 & 0.50 & 0.01 & 0.50 & 0.01 & 0.50 & 0.73 & 0.73 & 1.00\end{array}$

$\begin{array}{lllllllll}0.02 & 1.00 & 0.02 & 1.00 & 0.02 & 1.00 & 0.46 & 0.46 & 1.00\end{array}$

$\begin{array}{lllllllll}0.04 & 0.60 & 0.03 & 0.60 & 0.03 & 0.60 & 0.69 & 0.69 & 1.00\end{array}$

$\begin{array}{lllllllll}0.02 & 1.00 & 0.00 & 0.00 & 0.00 & 0.00 & 0.55 & 0.56 & 0.33\end{array}$

$\begin{array}{lllllllll}0.00 & 0.00 & 0.00 & 0.00 & 0.04 & 0.80 & 0.65 & 0.98 & 0.33\end{array}$

$\begin{array}{lllllllll}0.00 & 0.00 & 0.00 & 0.00 & 0.02 & 1.00 & 0.56 & 0.99 & 0.33\end{array}$

$\begin{array}{lllllllll}0.01 & 1.00 & 0.01 & 1.00 & 0.01 & 1.00 & 0.46 & 0.46 & 1.00\end{array}$

$\begin{array}{lllllllll}0.01 & 1.00 & 0.01 & 1.00 & 0.01 & 1.00 & 0.46 & 0.46 & 1.00\end{array}$

$\begin{array}{lllllllll}0.00 & 0.00 & 0.00 & 0.00 & 0.00 & 0.00 & 1.00 & 1.00 & 0.33\end{array}$ 
Cont'd Table 4. QCA Solution Sets Tables

Set leading to

Strategy type Minimized Solution Set

Trait present
Trait absent

Complete

Cons

Present Environmental migration

\begin{tabular}{|c|c|c|c|c|c|c|c|c|c|c|}
\hline ECL & jws & 0.10 & 0.68 & 0.11 & 0.71 & 0.10 & 0.70 & 0.67 & 0.67 & 1.00 \\
\hline ECFL & w & 0.09 & 0.65 & 0.10 & 0.68 & 0.09 & 0.67 & 0.69 & 0.68 & 1.00 \\
\hline ECSFTL & & 0.14 & 0.81 & 0.14 & 0.83 & 0.12 & 0.81 & 0.63 & 0.62 & 1.00 \\
\hline $\mathrm{RCL}$ & ews & 0.18 & 0.89 & 0.18 & 0.89 & 0.18 & 0.89 & 0.61 & 0.61 & 1.00 \\
\hline JRCFL & $\mathrm{w}$ & 0.10 & 0.87 & 0.10 & 0.87 & 0.10 & 0.87 & 0.58 & 0.58 & 1.00 \\
\hline CTL & jw & 0.00 & 0.00 & 0.16 & 0.82 & 0.00 & 0.00 & 0.65 & 0.65 & 0.33 \\
\hline JECFTL & & 0.00 & 0.00 & 0.00 & 0.00 & 0.06 & 0.80 & 0.65 & 0.97 & 0.33 \\
\hline ESTL & jwf & 0.05 & 0.75 & 0.03 & 0.57 & 0.00 & 0.00 & 0.64 & 0.65 & 0.67 \\
\hline ECSFL & $\mathrm{jr}$ & 0.04 & 0.71 & 0.05 & 0.78 & 0.00 & 0.00 & 0.60 & 0.61 & 0.67 \\
\hline RCL & $\mathrm{jft}$ & 0.06 & 1.00 & 0.05 & 1.00 & 0.05 & 1.00 & 0.48 & 0.48 & 1.00 \\
\hline RCFL & jet & 0.10 & 0.80 & 0.09 & 0.80 & 0.10 & 0.82 & 0.61 & 0.61 & 1.00 \\
\hline REC & jtl & 0.04 & 1.00 & 0.04 & 1.00 & 0.04 & 1.00 & 0.47 & 0.47 & 1.00 \\
\hline JRCL & et & 0.06 & 1.00 & 0.05 & 1.00 & 0.05 & 1.00 & 0.48 & 0.48 & 1.00 \\
\hline JRCSFTL & & 0.04 & 0.71 & 0.04 & 0.75 & 0.04 & 0.71 & 0.62 & 0.62 & 1.00 \\
\hline CSFL & jew & 0.12 & 0.94 & 0.12 & 0.94 & 0.00 & 0.00 & 0.50 & 0.53 & 0.67 \\
\hline CFTL & jre & 0.00 & 0.00 & 0.03 & 1.00 & 0.00 & 0.00 & 0.56 & 0.56 & 0.33 \\
\hline CFL & jrwt & 0.00 & 0.00 & 0.00 & 0.00 & 0.04 & 0.86 & 0.62 & 0.98 & 0.33 \\
\hline CSFL & jrw & 0.00 & 0.00 & 0.00 & 0.00 & 0.03 & 0.67 & 0.70 & 0.99 & 0.33 \\
\hline CT & jewfl & 0.00 & 0.00 & 0.00 & 0.00 & 0.03 & 1.00 & 0.56 & 0.99 & 0.33 \\
\hline ESTL & $\mathrm{jr}$ & 0.00 & 0.00 & 0.00 & 0.00 & 0.02 & 0.50 & 0.78 & 0.99 & 0.33 \\
\hline FTL & rews & 0.02 & 1.00 & 0.02 & 1.00 & 0.02 & 1.00 & 0.46 & 0.46 & 1.00 \\
\hline CST & jewfl & 0.02 & 1.00 & 0.02 & 1.00 & 0.00 & 0.00 & 0.45 & 0.46 & 0.67 \\
\hline RWCF & jest & 0.02 & 0.75 & 0.02 & 0.75 & 0.02 & 0.75 & 0.60 & 0.60 & 1.00 \\
\hline EWCSF & jrt & 0.00 & 0.00 & 0.00 & 0.00 & 0.02 & 1.00 & 0.55 & 0.99 & 0.33 \\
\hline RECT & jsfl & 0.02 & 1.00 & 0.02 & 1.00 & 0.02 & 1.00 & 0.46 & 0.46 & 1.00 \\
\hline JEWCTL & rs & 0.01 & 0.50 & 0.01 & 0.50 & 0.01 & 0.50 & 0.73 & 0.73 & 1.00 \\
\hline JRL & esft & 0.02 & 1.00 & 0.02 & 1.00 & 0.02 & 1.00 & 0.46 & 0.46 & 1.00 \\
\hline JRSFTL & $\mathrm{e}$ & 0.02 & 0.40 & 0.02 & 0.40 & 0.02 & 0.40 & 0.79 & 0.79 & 1.00 \\
\hline EFL & jrst & 0.00 & 0.00 & 0.00 & 0.00 & 0.03 & 0.80 & 0.65 & 0.99 & 0.33 \\
\hline WCFTL & jre & 0.02 & 1.00 & 0.00 & 0.00 & 0.00 & 0.00 & 0.55 & 0.55 & 0.33 \\
\hline JWCSTL & ref & 0.00 & 0.00 & 0.00 & 0.00 & 0.00 & 0.00 & 1.00 & 1.00 & 1.00 \\
\hline JEWFL & rest & 0.01 & 1.00 & 0.01 & 1.00 & 0.01 & 1.00 & 0.46 & 0.46 & 1.00 \\
\hline JEWCSL & $\mathrm{rft}$ & 0.01 & 1.00 & 0.01 & 1.00 & 0.01 & 1.00 & 0.46 & 0.46 & 1.00 \\
\hline E & jresft & 0.00 & 0.00 & 0.00 & 0.00 & 0.01 & 1.00 & 0.55 & 1.00 & 0.33 \\
\hline
\end{tabular}


Cont'd Table 4. QCA Solution Sets Tables

\begin{tabular}{|c|c|c|c|c|c|c|c|c|c|c|c|c|}
\hline \multirow{2}{*}{$\begin{array}{l}\text { Set } \\
\text { leading to }\end{array}$} & \multirow{2}{*}{$\begin{array}{l}\text { Strategy } \\
\text { type }\end{array}$} & \multicolumn{2}{|c|}{ Minimized Solution Set } & \multicolumn{2}{|c|}{ Complete } & \multicolumn{2}{|c|}{ Missing=1 } & \multicolumn{2}{|c|}{ Missing $=0$} & \multicolumn{3}{|c|}{ Reliability } \\
\hline & & Trait present & Trait absent & Cons & $\mathrm{Cov}$ & Cons & Cov & Cons & $\mathrm{Cov}$ & Cons & Cov & Sol \\
\hline \multirow[t]{33}{*}{ Present } & Household & JECFTL & & 0.00 & 0.00 & 0.00 & 0.00 & 0.13 & 0.55 & 0.76 & 0.94 & 0.33 \\
\hline & migration & ECL & jws & 0.18 & 0.42 & 0.17 & 0.38 & 0.17 & 0.40 & 0.87 & 0.87 & 1.00 \\
\hline & & ECFL & $\mathrm{w}$ & 0.21 & 0.53 & 0.19 & 0.47 & 0.19 & 0.50 & 0.83 & 0.83 & 1.00 \\
\hline & & ECSFTL & & 0.18 & 0.36 & 0.17 & 0.33 & 0.17 & 0.36 & 0.90 & 0.90 & 1.00 \\
\hline & & RCL & ews & 0.02 & 0.04 & 0.02 & 0.04 & 0.04 & 0.07 & 0.98 & 0.99 & 1.00 \\
\hline & & JRCFL & $\mathrm{w}$ & 0.05 & 0.13 & 0.04 & 0.13 & 0.04 & 0.13 & 0.96 & 0.96 & 1.00 \\
\hline & & CTL & jw & 0.00 & 0.00 & 0.09 & 0.15 & 0.00 & 0.00 & 0.93 & 0.93 & 0.33 \\
\hline & & ESTL & jwf & 0.11 & 0.63 & 0.00 & 0.00 & 0.00 & 0.00 & 0.72 & 0.73 & 0.33 \\
\hline & & ECSFL & $\mathrm{jr}$ & 0.11 & 0.71 & 0.13 & 0.67 & 0.00 & 0.00 & 0.64 & 0.66 & 0.67 \\
\hline & & RCL & jft & 0.07 & 0.43 & 0.06 & 0.43 & 0.06 & 0.43 & 0.80 & 0.80 & 1.00 \\
\hline & & RCFL & jet & 0.05 & 0.13 & 0.04 & 0.13 & 0.04 & 0.12 & 0.95 & 0.95 & 1.00 \\
\hline & & REC & jtl & 0.07 & 0.60 & 0.06 & 0.60 & 0.06 & 0.60 & 0.71 & 0.71 & 1.00 \\
\hline & & JRCL & et & 0.02 & 0.14 & 0.02 & 0.14 & 0.02 & 0.14 & 0.93 & 0.93 & 1.00 \\
\hline & & JRCSFTL & & 0.00 & 0.00 & 0.00 & 0.00 & 0.00 & 0.00 & 1.00 & 1.00 & 1.00 \\
\hline & & CSFL & jew & 0.09 & 0.25 & 0.09 & 0.24 & 0.11 & 0.83 & 0.69 & 0.92 & 0.67 \\
\hline & & CFTL & jre & 0.00 & 0.00 & 0.02 & 0.25 & n.l & n.l & 0.86 & 0.88 & 0.33 \\
\hline & & ESTL & $\mathrm{jr}$ & 0.00 & 0.00 & 0.13 & 0.86 & 0.11 & 0.83 & 0.58 & 0.64 & 0.33 \\
\hline & & CT & jewfl & 0.00 & 0.00 & 0.00 & 0.00 & 0.00 & 0.00 & 1.00 & 1.00 & 0.33 \\
\hline & & FTL & rews & 0.02 & 0.50 & 0.02 & 0.50 & 0.02 & 0.50 & 0.74 & 0.74 & 1.00 \\
\hline & & CST & jewfl & 0.00 & 0.00 & 0.00 & 0.00 & 0.00 & 0.00 & 1.00 & 1.00 & 1.00 \\
\hline & & RWCF & jest & 0.00 & 0.00 & 0.00 & 0.00 & 0.00 & 0.00 & 1.00 & 1.00 & 1.00 \\
\hline & & RECT & jsfl & 0.00 & 0.00 & 0.00 & 0.00 & 0.00 & 0.00 & 1.00 & 1.00 & 1.00 \\
\hline & & JEWCTL & rs & 0.05 & 1.00 & 0.04 & 1.00 & 0.04 & 1.00 & 0.48 & 0.48 & 1.00 \\
\hline & & JRL & esft & 0.00 & 0.00 & 0.00 & 0.00 & 0.00 & 0.00 & 1.00 & 1.00 & 1.00 \\
\hline & & JRSFTL & $\mathrm{e}$ & 0.02 & 0.20 & 0.02 & 0.20 & 0.02 & 0.20 & 0.90 & 0.90 & 1.00 \\
\hline & & WCFTL & jre & 0.00 & 0.00 & 0.00 & 0.00 & 0.06 & 0.43 & 0.81 & 0.97 & 0.67 \\
\hline & & EFL & jrst & 0.00 & 0.00 & 0.00 & 0.00 & 0.04 & 0.40 & 0.82 & 0.98 & 0.33 \\
\hline & & EWCSF & jrt & 0.00 & 0.00 & 0.00 & 0.00 & 0.04 & 1.00 & 0.56 & 0.98 & 0.33 \\
\hline & & JWCSTL & ref & 0.00 & 0.00 & 0.00 & 0.00 & 0.00 & 0.00 & 1.00 & 1.00 & 1.00 \\
\hline & & JEST & $\mathrm{rcf}$ & 0.00 & 0.00 & 0.00 & 0.00 & 0.00 & 0.00 & 1.00 & 1.00 & 1.00 \\
\hline & & JEWFL & rcst & 0.00 & 0.00 & 0.00 & 0.00 & 0.00 & 0.00 & 1.00 & 1.00 & 1.00 \\
\hline & & JEWCSL & $\mathrm{rft}$ & 0.00 & 0.00 & 0.00 & 0.00 & 0.00 & 0.00 & 1.00 & 1.00 & 1.00 \\
\hline & & $\mathrm{E}$ & jresft & 0.00 & 0.00 & 0.00 & 0.00 & 0.02 & 1.00 & 0.56 & 0.99 & 0.33 \\
\hline
\end{tabular}


Cont'd Table 4. QCA Solution Sets Tables

Set leading to

Absent
Strategy type All
Minimized Solution Set

Trait present Trait absent

$\begin{array}{ll}\text { ECFL } & \text { w } \\ \text { ECSFTL } & \\ \text { RCL } & \text { ews } \\ \text { JRCFL } & \text { w } \\ \text { ECL } & \text { jws } \\ \text { CTL } & \text { jw }\end{array}$

JECFTL

CSFL jew

ESTL jr

ESTL jwf

ECSFL jr

RCL jft

RCFL jet

REC jtl

JRCL et

JRCSFTL

CFTL jre

CT jewfl

ESTL jr

CFL jrwt

CSFL jrw

FTL rews

CST jewfl

RWCF jest

RECT jsfl

JEWCTL rs

JRL esft

JRSFTL e

WCFTL jre

EFL jrst

EWCSF jrt

RWCF jest

E jrcsft

JWCSTL ref

JEWFL rest

JEWCSL $\quad \mathrm{rft}$
Complete $\quad$ Missing $=1 \quad$ Missing $=0 \quad$ Reliability

Cons Cov Cons Cov Cons Cov Cons Cov Sol

$\begin{array}{lllllllll}0.00 & 0.00 & 0.00 & 0.00 & 0.00 & 0.00 & 1.00 & 1.00 & 1.00\end{array}$

$\begin{array}{lllllllll}0.09 & 0.10 & 0.09 & 0.09 & 0.09 & 0.10 & 1.00 & 1.00 & 1.00\end{array}$

$\begin{array}{lllllllll}0.18 & 0.15 & 0.18 & 0.15 & 0.18 & 0.14 & 0.98 & 0.98 & 1.00\end{array}$

$\begin{array}{lllllllll}0.05 & 0.07 & 0.05 & 0.07 & 0.05 & 0.07 & 0.99 & 0.99 & 1.00\end{array}$

$\begin{array}{lllllllll}0.05 & 0.05 & 0.05 & 0.05 & 0.05 & 0.05 & 1.00 & 1.00 & 1.00\end{array}$

$\begin{array}{lllllllll}0.00 & 0.00 & 0.09 & 0.07 & 0.00 & 0.00 & 0.95 & 0.95 & 0.33\end{array}$

$\begin{array}{lllllllll}0.00 & 0.00 & 0.00 & 0.00 & 0.05 & 0.10 & 0.96 & 0.98 & 0.33\end{array}$

$\begin{array}{lllllllll}0.09 & 0.13 & 0.09 & 0.12 & 0.00 & 0.00 & 0.94 & 0.95 & 0.67\end{array}$

$\begin{array}{lllllllll}0.00 & 0.00 & 0.00 & 0.00 & 0.00 & 0.00 & 1.00 & 1.00 & 0.33\end{array}$

$\begin{array}{lllllllll}0.05 & 0.13 & 0.00 & 0.00 & 0.00 & 0.00 & 0.94 & 0.95 & 0.33\end{array}$

$\begin{array}{lllllllll}0.05 & 0.14 & 0.05 & 0.11 & 0.00 & 0.00 & 0.93 & 0.94 & 0.67\end{array}$

$\begin{array}{lllllllll}0.18 & 0.57 & 0.18 & 0.57 & 0.18 & 0.57 & 0.79 & 0.79 & 1.00\end{array}$

$\begin{array}{lllllllll}0.09 & 0.13 & 0.09 & 0.13 & 0.09 & 0.12 & 0.98 & 0.98 & 1.00\end{array}$

$\begin{array}{lllllllll}0.14 & 0.60 & 0.14 & 0.60 & 0.14 & 0.60 & 0.75 & 0.75 & 1.00\end{array}$

$\begin{array}{lllllllll}0.05 & 0.14 & 0.05 & 0.14 & 0.05 & 0.14 & 0.95 & 0.95 & 1.00\end{array}$

$\begin{array}{lllllllll}0.09 & 0.29 & 0.09 & 0.25 & 0.09 & 0.29 & 0.90 & 0.90 & 1.00\end{array}$

$\begin{array}{lllllllll}0.00 & 0.00 & 0.00 & 0.00 & \text { n.a } & \text { n.a } & 1.00 & 1.00 & 0.33\end{array}$

$\begin{array}{lllllllll}0.00 & 0.00 & 0.00 & 0.00 & 0.05 & 0.25 & 0.89 & 0.98 & 0.33\end{array}$

$\begin{array}{lllllllll}0.00 & 0.00 & 0.00 & 0.00 & 0.00 & 0.00 & 1.00 & 1.00 & 0.33\end{array}$

$\begin{array}{lllllllll}0.00 & 0.00 & 0.00 & 0.00 & 0.05 & 0.14 & 0.94 & 0.98 & 0.33\end{array}$

$\begin{array}{lllllllll}0.00 & 0.00 & 0.00 & 0.00 & 0.05 & 0.17 & 0.93 & 0.98 & 0.33\end{array}$

$\begin{array}{lllllllll}0.00 & 0.00 & 0.00 & 0.00 & 0.00 & 0.00 & 1.00 & 1.00 & 1.00\end{array}$

$\begin{array}{lllllllll}0.00 & 0.00 & 0.00 & 0.00 & \text { n.a } & \text { n.a } & 1.00 & 1.00 & 0.33\end{array}$

$\begin{array}{lllllllll}0.05 & 0.25 & 0.05 & 0.25 & \text { n.a } & \text { n.a } & 0.88 & 0.88 & 0.67\end{array}$

$\begin{array}{lllllllll}0.00 & 0.00 & 0.00 & 0.00 & 0.00 & 0.00 & 1.00 & 1.00 & 1.00\end{array}$

$\begin{array}{lllllllll}0.00 & 0.00 & 0.00 & 0.00 & 0.00 & 0.00 & 1.00 & 1.00 & 1.00\end{array}$

$\begin{array}{lllllllll}0.00 & 0.00 & 0.00 & 0.00 & 0.00 & 0.00 & 1.00 & 1.00 & 1.00\end{array}$

$\begin{array}{lllllllll}0.00 & 0.00 & 0.00 & 0.00 & 0.00 & 0.00 & 1.00 & 1.00 & 1.00\end{array}$

$\begin{array}{lllllllll}0.00 & 0.00 & 0.00 & 0.00 & 0.00 & 0.00 & 1.00 & 1.00 & 0.33\end{array}$

$\begin{array}{lllllllll}0.00 & 0.00 & 0.00 & 0.00 & 0.00 & 0.00 & 1.00 & 1.00 & 0.33\end{array}$

$\begin{array}{lllllllll}0.00 & 0.00 & 0.00 & 0.00 & 0.00 & 0.00 & 1.00 & 1.00 & 0.33\end{array}$

$\begin{array}{lllllllll}0.00 & 0.00 & 0.00 & 0.00 & 0.05 & 0.25 & 0.89 & 0.98 & 0.33\end{array}$

$\begin{array}{lllllllll}0.00 & 0.00 & 0.00 & 0.00 & 0.00 & 0.00 & 1.00 & 1.00 & 0.33\end{array}$

$\begin{array}{lllllllll}0.00 & 0.00 & 0.00 & 0.00 & 0.00 & 0.00 & 1.00 & 1.00 & 1.00\end{array}$

$\begin{array}{lllllllll}0.00 & 0.00 & 0.00 & 0.00 & 0.00 & 0.00 & 1.00 & 1.00 & 1.00\end{array}$

$\begin{array}{lllllllll}0.00 & 0.00 & 0.00 & 0.00 & 0.00 & 0.00 & 1.00 & 1.00 & 1.00\end{array}$ 
Cont'd Table 4. QCA Solution Sets Tables

Set leading to

Absent
Strategy type

Farm
Minimized Solution Set

Trait present

ECL

ECL
ECFL
ECSFTL

RCL

JRCFL

JECFTL

CTL

ESTL jwf

ECSFL jr

RCL jft

RCFL jet

REC jtl

JRCL et

JRCSFTL

CSFL jew

ESTL jr

CT jewf

CFTL jre

CFL jrwt

CSFL jrw

FTL rews

CST jewfl

RWCF jest

RECT jsfl

JEWCTL rs

JRL esft

JRSFTL e

WCFTL jre

EFL jrst

EWCSF jrt

JEWFL rest

JEWCSL $\quad \mathrm{rt}$
Complete Missing $=1 \quad$ Missing $=0 \quad$ Reliability

Cons Cov Cons Cov Cons Cov Cons Cov Sol

$\begin{array}{lllllllll}0.06 & 0.21 & 0.07 & 0.24 & 0.07 & 0.25 & 0.91 & 0.91 & 1.00\end{array}$

$\begin{array}{lllllllll}0.06 & 0.24 & 0.07 & 0.26 & 0.07 & 0.28 & 0.90 & 0.90 & 1.00\end{array}$

$\begin{array}{lllllllll}0.08 & 0.24 & 0.07 & 0.22 & 0.07 & 0.24 & 0.91 & 0.91 & 1.00\end{array}$

$\begin{array}{lllllllll}0.22 & 0.58 & 0.23 & 0.59 & 0.24 & 0.61 & 0.80 & 0.81 & 1.00\end{array}$

$\begin{array}{lllllllll}0.13 & 0.60 & 0.13 & 0.60 & 0.13 & 0.60 & 0.74 & 0.74 & 1.00\end{array}$

$\begin{array}{lllllllll}0.00 & 0.00 & 0.00 & 0.00 & 0.04 & 0.30 & 0.87 & 0.98 & 0.33\end{array}$

$\begin{array}{lllllllll}0.00 & 0.00 & 0.16 & 0.41 & 0.00 & 0.00 & 0.82 & 0.82 & 0.67\end{array}$

$\begin{array}{lllllllll}0.08 & 0.63 & \text { n.a } & \text { n.a } & 0.00 & 0.00 & 0.64 & 0.66 & 0.33\end{array}$

$\begin{array}{lllllllll}0.02 & 0.14 & 0.01 & 0.11 & 0.00 & 0.00 & 0.93 & 0.93 & 0.67\end{array}$

$\begin{array}{lllllllll}0.10 & 1.00 & 0.10 & 1.00 & 0.10 & 1.00 & 0.51 & 0.51 & 1.00\end{array}$

$\begin{array}{lllllllll}0.09 & 0.40 & 0.09 & 0.40 & 0.11 & 0.47 & 0.82 & 0.83 & 1.00\end{array}$

$\begin{array}{lllllllll}0.08 & 1.00 & 0.07 & 1.00 & 0.07 & 1.00 & 0.49 & 0.49 & 1.00\end{array}$

$\begin{array}{lllllllll}0.03 & 0.29 & 0.03 & 0.29 & 0.03 & 0.29 & 0.86 & 0.86 & 1.00\end{array}$

$\begin{array}{lllllllll}0.08 & 0.71 & 0.07 & 0.63 & 0.07 & 0.71 & 0.66 & 0.67 & 1.00\end{array}$

$\begin{array}{lllllllll}0.08 & 0.31 & 0.09 & 0.35 & 0.00 & 0.00 & 0.83 & 0.84 & 0.67\end{array}$

$\begin{array}{lllllllll}0.00 & 0.00 & 0.00 & 0.00 & 0.00 & 0.00 & 1.00 & 1.00 & 0.67\end{array}$

$\begin{array}{lllllllll}0.00 & 0.00 & 0.00 & 0.00 & 0.04 & 0.75 & 0.67 & 0.98 & 0.33\end{array}$

$\begin{array}{lllllllll}0.00 & 0.00 & 0.00 & 0.00 & 0.00 & 0.00 & 1.00 & 1.00 & 0.33\end{array}$

$\begin{array}{lllllllll}0.00 & 0.00 & 0.00 & 0.00 & 0.01 & 0.14 & 0.94 & 0.99 & 0.33\end{array}$

$\begin{array}{lllllllll}0.00 & 0.00 & 0.00 & 0.00 & 0.01 & 0.17 & 0.93 & 0.99 & 0.33\end{array}$

$\begin{array}{lllllllll}0.00 & 0.00 & 0.00 & 0.00 & 0.00 & 0.00 & 1.00 & 1.00 & 1.00\end{array}$

$\begin{array}{lllllllll}0.03 & 1.00 & 0.03 & 1.00 & 0.00 & 0.00 & 0.46 & 0.46 & 1.00\end{array}$

$\begin{array}{lllllllll}0.05 & 0.75 & 0.04 & 0.75 & 0.04 & 0.75 & 0.61 & 0.61 & 1.00\end{array}$

$\begin{array}{lllllllll}0.03 & 1.00 & 0.03 & 1.00 & 0.03 & 1.00 & 0.47 & 0.47 & 1.00\end{array}$

$\begin{array}{lllllllll}0.00 & 0.00 & 0.00 & 0.00 & 0.00 & 0.00 & 1.00 & 1.00 & 1.00\end{array}$

$\begin{array}{lllllllll}0.00 & 0.00 & 0.00 & 0.00 & 0.00 & 0.00 & 1.00 & 1.00 & 1.00\end{array}$

$\begin{array}{lllllllll}0.03 & 0.40 & 0.03 & 0.40 & 0.03 & 0.40 & 0.80 & 0.80 & 1.00\end{array}$

$\begin{array}{lllllllll}0.00 & 0.00 & 0.00 & 0.00 & 0.00 & 0.00 & 1.00 & 1.00 & 0.33\end{array}$

$\begin{array}{lllllllll}0.00 & 0.00 & 0.00 & 0.00 & 0.00 & 0.00 & 1.00 & 1.00 & 0.33\end{array}$

$\begin{array}{lllllllll}0.00 & 0.00 & 0.00 & 0.00 & 0.00 & 0.00 & 1.00 & 1.00 & 0.33\end{array}$

$\begin{array}{lllllllll}0.00 & 0.00 & 0.00 & 0.00 & 0.00 & 0.00 & 1.00 & 1.00 & 1.00\end{array}$

$\begin{array}{lllllllll}0.00 & 0.00 & 0.00 & 0.00 & 0.00 & 0.00 & 1.00 & 1.00 & 1.00\end{array}$ 
Cont'd Table 4. QCA Solution Sets Tables

\begin{tabular}{|c|c|c|c|c|c|c|c|c|c|c|c|c|}
\hline \multirow{2}{*}{$\begin{array}{l}\text { Set } \\
\text { leading to }\end{array}$} & \multirow{2}{*}{$\begin{array}{l}\text { Strategy } \\
\text { type }\end{array}$} & \multicolumn{2}{|c|}{ Minimized Solution Set } & \multicolumn{2}{|c|}{ Complete } & \multicolumn{2}{|c|}{ Missing $=1$} & \multicolumn{2}{|c|}{ Missing $=0$} & \multicolumn{2}{|c|}{ Reliability } & \multirow[b]{2}{*}{ Sol } \\
\hline & & Trait present & Trait absent & Cons & Cov & Cons & Cov & Cons & Cov & Cons & Cov & \\
\hline \multirow[t]{32}{*}{ Absent } & Off & $\mathrm{ECL}$ & jws & 0.12 & 0.42 & 0.12 & 0.38 & 0.12 & 0.40 & 0.84 & 0.84 & 1.00 \\
\hline & farm & ECFL & $\mathrm{w}$ & 0.09 & 0.35 & 0.09 & 0.32 & 0.09 & 0.33 & 0.86 & 0.86 & 1.00 \\
\hline & & ECSFTL & & 0.12 & 0.38 & 0.13 & 0.39 & 0.12 & 0.38 & 0.86 & 0.86 & 1.00 \\
\hline & & $\mathrm{RCL}$ & ews & 0.17 & 0.42 & 0.16 & 0.41 & 0.16 & 0.39 & 0.87 & 0.86 & 1.00 \\
\hline & & JRCFL & w & 0.14 & 0.60 & 0.13 & 0.60 & 0.13 & 0.60 & 0.74 & 0.74 & 1.00 \\
\hline & & CTL & $\mathrm{jw}$ & 0.00 & 0.00 & 0.13 & 0.33 & 0.00 & 0.00 & 0.85 & 0.85 & 0.33 \\
\hline & & JECFTL & & 0.00 & 0.00 & 0.00 & 0.00 & 0.04 & 0.30 & 0.87 & 0.98 & 0.33 \\
\hline & & ESTL & jwf & 0.03 & 0.25 & 0.00 & 0.00 & 0.00 & 0.00 & 0.89 & 0.89 & 0.33 \\
\hline & & ECSFL & jr & 0.05 & 0.43 & 0.04 & 0.33 & 0.00 & 0.00 & 0.80 & 0.80 & 0.67 \\
\hline & & $\mathrm{RCL}$ & $\mathrm{jft}$ & 0.08 & 0.71 & 0.07 & 0.71 & 0.07 & 0.71 & 0.65 & 0.65 & 1.00 \\
\hline & & RCFL & jet & 0.12 & 0.53 & 0.12 & 0.53 & 0.12 & 0.47 & 0.78 & 0.77 & 1.00 \\
\hline & & $\mathrm{REC}$ & $\mathrm{jtl}$ & 0.06 & 0.80 & 0.06 & 0.80 & 0.06 & 0.80 & 0.59 & 0.59 & 1.00 \\
\hline & & JRCL & et & 0.03 & 0.29 & 0.03 & 0.29 & 0.03 & 0.29 & 0.86 & 0.86 & 1.00 \\
\hline & & JRCSFTL & & 0.06 & 0.57 & 0.07 & 0.63 & 0.06 & 0.57 & 0.71 & 0.71 & 1.00 \\
\hline & & CSFL & jew & 0.15 & 0.63 & 0.15 & 0.59 & 0.00 & 0.00 & 0.69 & 0.72 & 0.67 \\
\hline & & ESTL & $\mathrm{jr}$ & 0.00 & 0.00 & 0.03 & 0.29 & 0.02 & 0.17 & 0.88 & 0.88 & 0.33 \\
\hline & & CFTL & jre & 0.00 & 0.00 & 0.00 & 0.00 & 0.00 & 0.00 & 1.00 & 1.00 & 0.33 \\
\hline & & CT & jewfl & 0.00 & 0.00 & 0.00 & 0.00 & 0.02 & 0.25 & 0.89 & 0.99 & 0.33 \\
\hline & & CFL & jrwt & 0.00 & 0.00 & 0.00 & 0.00 & 0.03 & 0.29 & 0.87 & 0.99 & 0.33 \\
\hline & & CSFL & jrw & 0.00 & 0.00 & 0.00 & 0.00 & 0.03 & 0.33 & 0.85 & 0.99 & 0.33 \\
\hline & & FTL & rews & 0.00 & 0.00 & 0.00 & 0.00 & 0.00 & 0.00 & 1.00 & 1.00 & 1.00 \\
\hline & & CST & jewfl & 0.00 & 0.00 & 0.00 & 0.00 & 0.00 & 0.00 & 1.00 & 1.00 & 0.67 \\
\hline & & RWCF & jest & 0.03 & 0.50 & 0.03 & 0.50 & 0.03 & 0.50 & 0.74 & 0.74 & 1.00 \\
\hline & & RECT & jsfl & 0.00 & 0.00 & 0.00 & 0.00 & 0.00 & 0.00 & 1.00 & 1.00 & 1.00 \\
\hline & & JEWCTL & $\mathrm{rs}$ & 0.02 & 0.50 & 0.02 & 0.50 & 0.02 & 0.50 & 0.73 & 0.73 & 1.00 \\
\hline & & JRL & esft & 0.00 & 0.00 & 0.00 & 0.00 & 0.00 & 0.00 & 1.00 & 1.00 & 1.00 \\
\hline & & JRSFTL & $\mathrm{e}$ & 0.03 & 0.40 & 0.03 & 0.40 & 0.03 & 0.40 & 0.80 & 0.80 & 1.00 \\
\hline & & WCFTL & jre & 0.00 & 0.00 & 0.00 & 0.00 & 0.00 & 0.00 & 1.00 & 1.00 & 0.33 \\
\hline & & EFL & jrst & 0.00 & 0.00 & 0.00 & 0.00 & 0.02 & 0.20 & 0.91 & 0.99 & 0.33 \\
\hline & & EWCSF & jrt & 0.00 & 0.00 & 0.00 & 0.00 & 0.00 & 0.00 & 1.00 & 1.00 & 0.33 \\
\hline & & JWCSTL & ref & 0.00 & 0.00 & 0.00 & 0.00 & 0.02 & 1.00 & 0.55 & 0.99 & 1.00 \\
\hline & & JEWFL & rest & 0.00 & 0.00 & 0.00 & 0.00 & 0.00 & 0.00 & 1.00 & 1.00 & 1.00 \\
\hline
\end{tabular}


Cont'd Table 4. QCA Solution Sets Tables

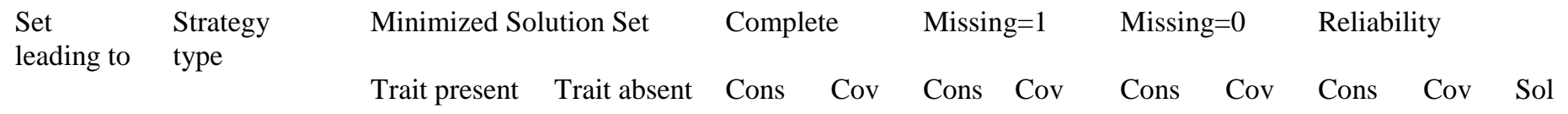

\begin{tabular}{|c|c|c|c|c|c|c|c|c|c|c|c|c|}
\hline \multirow[t]{32}{*}{ Absent } & \multirow[t]{32}{*}{$\begin{array}{l}\text { Environmental } \\
\text { migration }\end{array}$} & ECL & jws & 0.10 & 0.68 & 0.16 & 0.82 & n.a & n.a & 0.65 & 0.64 & 0.67 \\
\hline & & ECFL & $\mathrm{w}$ & 0.09 & 0.65 & 0.10 & 0.68 & 0.09 & 0.67 & 0.69 & 0.68 & 1.00 \\
\hline & & ECSFTL & & 0.14 & 0.81 & 0.14 & 0.83 & 0.12 & 0.81 & 0.63 & 0.62 & 1.00 \\
\hline & & RCL & ews & 0.18 & 0.89 & 0.18 & 0.89 & 0.18 & 0.89 & 0.61 & 0.61 & 1.00 \\
\hline & & JRCFL & $\mathrm{w}$ & 0.10 & 0.87 & 0.10 & 0.87 & 0.10 & 0.87 & 0.58 & 0.58 & 1.00 \\
\hline & & JECFTL & & 0.00 & 0.00 & 0.00 & 0.00 & 0.06 & 0.80 & 0.65 & 0.97 & 0.33 \\
\hline & & ECL & jws & 0.00 & 0.00 & 0.11 & 0.71 & 0.10 & 0.70 & 0.65 & 0.70 & 0.67 \\
\hline & & ESTL & jwf & 0.05 & 0.75 & 0.00 & 0.00 & 0.03 & 1.00 & 0.52 & 0.67 & 0.67 \\
\hline & & ECSFL & jr & 0.04 & 0.71 & 0.05 & 0.78 & 0.00 & 0.00 & 0.60 & 0.61 & 0.67 \\
\hline & & $\mathrm{RCL}$ & $\mathrm{jft}$ & 0.06 & 1.00 & 0.05 & 1.00 & 0.05 & 1.00 & 0.48 & 0.48 & 1.00 \\
\hline & & JRCSFTL & & 0.04 & 0.71 & 0.04 & 0.75 & 0.04 & 0.71 & 0.62 & 0.62 & 1.00 \\
\hline & & RCFL & jet & 0.10 & 0.80 & 0.09 & 0.80 & 0.10 & 0.82 & 0.61 & 0.61 & 1.00 \\
\hline & & REC & jtl & 0.04 & 1.00 & 0.04 & 1.00 & 0.04 & 1.00 & 0.47 & 0.47 & 1.00 \\
\hline & & JRCL & et & 0.06 & 1.00 & 0.05 & 1.00 & 0.05 & 1.00 & 0.48 & 0.48 & 1.00 \\
\hline & & CSFL & jew & 0.12 & 0.94 & 0.12 & 0.94 & 0.00 & 0.00 & 0.50 & 0.53 & 0.67 \\
\hline & & ESTL & $\mathrm{jr}$ & 0.00 & 0.00 & 0.03 & 0.57 & 0.02 & 0.50 & 0.71 & 0.75 & 0.67 \\
\hline & & CFTL & jre & 0.00 & 0.00 & 0.03 & 1.00 & 0.00 & 0.00 & 0.56 & 0.56 & 0.33 \\
\hline & & CFL & jrwt & 0.00 & 0.00 & 0.00 & 0.00 & 0.04 & 0.86 & 0.62 & 0.98 & 0.33 \\
\hline & & CSFL & jrw & 0.00 & 0.00 & 0.00 & 0.00 & 0.03 & 0.67 & 0.70 & 0.99 & 0.33 \\
\hline & & FTL & rews & 0.02 & 1.00 & 0.02 & 1.00 & 0.02 & 1.00 & 0.46 & 0.46 & 1.00 \\
\hline & & CST & jewfl & 0.02 & 1.00 & 0.02 & 1.00 & 0.00 & 0.00 & 0.45 & 0.46 & 0.33 \\
\hline & & RWCF & jest & 0.02 & 0.75 & 0.02 & 0.75 & 0.02 & 0.75 & 0.60 & 0.60 & 1.00 \\
\hline & & EWCSF & jrt & 0.00 & 0.00 & 0.00 & 0.00 & 0.02 & 1.00 & 0.55 & 0.99 & 0.33 \\
\hline & & RECT & jsfl & 0.02 & 1.00 & 0.02 & 1.00 & 0.02 & 1.00 & 0.46 & 0.46 & 1.00 \\
\hline & & JEWCTL & rs & 0.01 & 0.50 & 0.01 & 0.50 & 0.01 & 0.50 & 0.73 & 0.73 & 1.00 \\
\hline & & JRL & esft & 0.02 & 1.00 & 0.02 & 1.00 & 0.02 & 1.00 & 0.46 & 0.46 & 1.00 \\
\hline & & JRSFTL & $\mathrm{e}$ & 0.02 & 0.40 & 0.02 & 0.40 & 0.02 & 0.40 & 0.79 & 0.79 & 1.00 \\
\hline & & EFL & jrst & 0.00 & 0.00 & 0.00 & 0.00 & 0.03 & 0.80 & 0.65 & 0.99 & 0.33 \\
\hline & & WCFTL & jre & 0.02 & 1.00 & 0.00 & 0.00 & 0.00 & 0.00 & 0.55 & 0.55 & 0.33 \\
\hline & & JEWFL & rest & 0.01 & 1.00 & 0.01 & 1.00 & 0.01 & 1.00 & 0.46 & 0.46 & 1.00 \\
\hline & & JEWCSL & $\mathrm{rft}$ & 0.01 & 1.00 & 0.01 & 1.00 & 0.01 & 1.00 & 0.46 & 0.46 & 1.00 \\
\hline & & E & jresft & 0.00 & 0.00 & 0.00 & 0.00 & 0.01 & 1.00 & 0.55 & 1.00 & 0.33 \\
\hline
\end{tabular}


Cont'd Table 4. QCA Solution Sets Tables

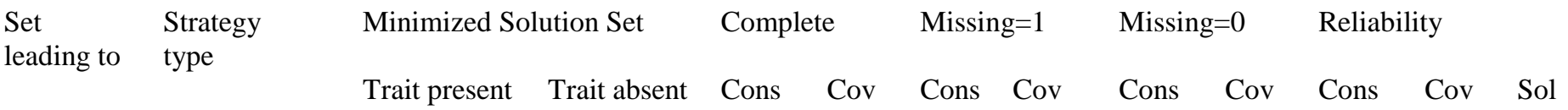

Absent

\begin{tabular}{|c|c|c|c|c|c|c|c|c|c|c|c|}
\hline \multirow{34}{*}{$\begin{array}{l}\text { Household } \\
\text { migration }\end{array}$} & CTL & jw & 0.00 & 0.00 & 0.20 & 0.85 & 0.00 & 0.00 & 0.63 & 0.63 & 0.33 \\
\hline & ECL & jws & 0.10 & 0.58 & 0.11 & 0.62 & 0.10 & 0.60 & 0.73 & 0.73 & 1.00 \\
\hline & ECFL & $\mathrm{w}$ & 0.07 & 0.47 & 0.09 & 0.53 & 0.08 & 0.50 & 0.77 & 0.77 & 1.00 \\
\hline & ECSFTL & & 0.13 & 0.64 & 0.14 & 0.67 & 0.12 & 0.64 & 0.72 & 0.71 & 1.00 \\
\hline & RCL & ews & 0.23 & 0.96 & 0.22 & 0.96 & 0.22 & 0.93 & 0.60 & 0.60 & 1.00 \\
\hline & JRCFL & $\mathrm{w}$ & 0.13 & 0.88 & 0.12 & 0.88 & 0.12 & 0.88 & 0.59 & 0.59 & 1.00 \\
\hline & JECFTL & & 0.00 & 0.00 & 0.00 & 0.00 & 0.04 & 0.46 & 0.80 & 0.98 & 0.33 \\
\hline & CFL & jrwt & 0.00 & 0.00 & 0.00 & 0.00 & 0.03 & 0.57 & 0.75 & 0.98 & 0.33 \\
\hline & CSFL & jrw & 0.00 & 0.00 & 0.00 & 0.00 & 0.01 & 0.17 & 0.93 & 1.00 & 0.33 \\
\hline & ESTL & jwf & 0.03 & 0.38 & 0.00 & 0.00 & 0.00 & 0.00 & 0.83 & 0.83 & 0.33 \\
\hline & ECSFL & $\mathrm{jr}$ & 0.02 & 0.29 & 0.03 & 0.33 & 0.00 & 0.00 & 0.83 & 0.84 & 0.67 \\
\hline & RCL & $\mathrm{jft}$ & 0.04 & 0.57 & 0.03 & 0.57 & 0.03 & 0.57 & 0.71 & 0.71 & 1.00 \\
\hline & RCFL & jet & 0.12 & 0.87 & 0.11 & 0.87 & 0.13 & 0.88 & 0.59 & 0.59 & 1.00 \\
\hline & REC & jtl & 0.02 & 0.40 & 0.02 & 0.40 & 0.02 & 0.40 & 0.79 & 0.79 & 1.00 \\
\hline & JRCL & et & 0.06 & 0.86 & 0.05 & 0.86 & 0.05 & 0.86 & 0.56 & 0.56 & 1.00 \\
\hline & JRCSFTL & & 0.07 & 1.00 & 0.08 & 1.00 & 0.07 & 1.00 & 0.49 & 0.49 & 1.00 \\
\hline & CSFL & jew & 0.11 & 0.75 & 0.11 & 0.77 & 0.00 & 0.00 & 0.60 & 0.62 & 0.67 \\
\hline & ESTL & $\mathrm{jr}$ & 0.00 & 0.00 & 0.01 & 0.14 & 0.01 & 0.17 & 0.92 & 0.94 & 0.67 \\
\hline & $\mathrm{CT}$ & jewfl & 0.00 & 0.00 & 0.00 & 0.00 & 0.03 & 1.00 & 0.56 & 0.98 & 0.33 \\
\hline & CFTL & jre & 0.00 & 0.00 & 0.03 & 0.75 & 0.00 & 0.00 & 0.67 & 0.67 & 0.33 \\
\hline & FTL & rews & 0.01 & 0.50 & 0.01 & 0.50 & 0.01 & 0.50 & 0.73 & 0.73 & 1.00 \\
\hline & CST & jewfl & 0.02 & 1.00 & 0.02 & 1.00 & 0.00 & 0.00 & 0.46 & 0.46 & 0.67 \\
\hline & RWCF & jest & 0.04 & 1.00 & 0.03 & 1.00 & 0.03 & 1.00 & 0.47 & 0.47 & 1.00 \\
\hline & EWCSF & jrt & 0.00 & 0.00 & 0.00 & 0.00 & 0.00 & 0.00 & 1.00 & 1.00 & 0.33 \\
\hline & RECT & jsfl & 0.02 & 1.00 & 0.02 & 1.00 & 0.02 & 1.00 & 0.46 & 0.46 & 1.00 \\
\hline & JEWCTL & rs & 0.00 & 0.00 & 0.00 & 0.00 & 0.00 & 0.00 & 1.00 & 1.00 & 1.00 \\
\hline & JRL & esft & 0.02 & 1.00 & 0.02 & 1.00 & 0.02 & 1.00 & 0.46 & 0.46 & 1.00 \\
\hline & JRSFTL & $\mathrm{e}$ & 0.04 & 0.80 & 0.03 & 0.80 & 0.03 & 0.80 & 0.58 & 0.58 & 1.00 \\
\hline & EFL & jrst & 0.00 & 0.00 & 0.00 & 0.00 & 0.03 & 0.60 & 0.73 & 0.99 & 0.33 \\
\hline & WCFTL & jre & 0.02 & 1.00 & 0.00 & 0.00 & 0.00 & 0.00 & 0.55 & 0.55 & 0.33 \\
\hline & JEST & $\mathrm{rcf}$ & 0.01 & 1.00 & 0.01 & 1.00 & 0.01 & 1.00 & 0.46 & 0.46 & 1.00 \\
\hline & JEWFL & rest & 0.01 & 1.00 & 0.01 & 1.00 & 0.01 & 1.00 & 0.46 & 0.46 & 1.00 \\
\hline & JEWCSL & $\mathrm{rft}$ & 0.01 & 1.00 & 0.01 & 1.00 & 0.01 & 1.00 & 0.46 & 0.46 & 1.00 \\
\hline & JWCSTL & ref & 0.01 & 1.00 & 0.01 & 1.00 & 0.01 & 1.00 & 0.46 & 0.46 & 1.00 \\
\hline
\end{tabular}


Table 5. Truth Tables QCA Type Household Traits

\begin{tabular}{|c|c|c|c|c|c|c|c|c|c|c|}
\hline & Rancher & Region & Education (female) & Water & Climate & Social & Financial & Title & Livestock & Present \\
\hline & $\mathrm{J}$ & $\mathrm{R}$ & $\mathrm{E}$ & $\mathrm{W}$ & $\mathrm{C}$ & $\mathrm{S}$ & $\mathrm{F}$ & $\mathrm{T}$ & $\mathrm{L}$ & $\mathrm{Y}$ \\
\hline \multirow[t]{41}{*}{ Complete } & 0 & 0 & 0 & 0 & 0 & 0 & 1 & 1 & 1 & 1 \\
\hline & 0 & 0 & 0 & 0 & 1 & 1 & 0 & 1 & 0 & 1 \\
\hline & 0 & 0 & 0 & 0 & 1 & 1 & 1 & 0 & 1 & 1 \\
\hline & 0 & 0 & 0 & 0 & 1 & 1 & 1 & 1 & 1 & 1 \\
\hline & 0 & 0 & 0 & 1 & 1 & 0 & 1 & 1 & 1 & 1 \\
\hline & 0 & 0 & 0 & 1 & 1 & 1 & 1 & 1 & 1 & 1 \\
\hline & 0 & 0 & 1 & 0 & 0 & 1 & 0 & 1 & 1 & 1 \\
\hline & 0 & 0 & 1 & 0 & 1 & 0 & 0 & 0 & 1 & 1 \\
\hline & 0 & 0 & 1 & 0 & 1 & 0 & 0 & 1 & 1 & 1 \\
\hline & 0 & 0 & 1 & 0 & 1 & 0 & 1 & 0 & 1 & 1 \\
\hline & 0 & 0 & 1 & 0 & 1 & 0 & 1 & 1 & 1 & 1 \\
\hline & 0 & 0 & 1 & 0 & 1 & 1 & 0 & 1 & 1 & 1 \\
\hline & 0 & 0 & 1 & 0 & 1 & 1 & 1 & 0 & 1 & 1 \\
\hline & 0 & 0 & 1 & 0 & 1 & 1 & 1 & 1 & 1 & 1 \\
\hline & 0 & 0 & 1 & 1 & 1 & 1 & 1 & 0 & 1 & 1 \\
\hline & 0 & 0 & 1 & 1 & 1 & 1 & 1 & 1 & 1 & 1 \\
\hline & 0 & 1 & 0 & 0 & 0 & 0 & 1 & 1 & 1 & 1 \\
\hline & 0 & 1 & 0 & 0 & 1 & 0 & 0 & 0 & 1 & 1 \\
\hline & 0 & 1 & 0 & 0 & 1 & 0 & 0 & 1 & 0 & 1 \\
\hline & 0 & 1 & 0 & 0 & 1 & 0 & 0 & 1 & 1 & 1 \\
\hline & 0 & 1 & 0 & 0 & 1 & 0 & 1 & 0 & 1 & 1 \\
\hline & 0 & 1 & 0 & 0 & 1 & 0 & 1 & 1 & 1 & 1 \\
\hline & 0 & 1 & 0 & 0 & 1 & 1 & 0 & 0 & 0 & 1 \\
\hline & 0 & 1 & 0 & 0 & 1 & 1 & 0 & 1 & 0 & 1 \\
\hline & 0 & 1 & 0 & 0 & 1 & 1 & 0 & 1 & 1 & 1 \\
\hline & 0 & 1 & 0 & 0 & 1 & 1 & 1 & 0 & 1 & 1 \\
\hline & 0 & 1 & 0 & 0 & 1 & 1 & 1 & 1 & 1 & 1 \\
\hline & 0 & 1 & 0 & 1 & 1 & 0 & 0 & 0 & 1 & 1 \\
\hline & 0 & 1 & 0 & 1 & 1 & 0 & 1 & 0 & 0 & 1 \\
\hline & 0 & 1 & 0 & 1 & 1 & 0 & 1 & 0 & 1 & 1 \\
\hline & 0 & 1 & 0 & 1 & 1 & 0 & 1 & 1 & 1 & 1 \\
\hline & 0 & 1 & 0 & 1 & 1 & 1 & 1 & 0 & 1 & 1 \\
\hline & 0 & 1 & 1 & 0 & 0 & 0 & 0 & 1 & 1 & 1 \\
\hline & 0 & 1 & 1 & 0 & 0 & 0 & 1 & 1 & 1 & 1 \\
\hline & 0 & 1 & 1 & 0 & 0 & 1 & 0 & 1 & 1 & 1 \\
\hline & 0 & 1 & 1 & 0 & 1 & 0 & 0 & 0 & 0 & 1 \\
\hline & 0 & 1 & 1 & 0 & 1 & 0 & 0 & 0 & 1 & 1 \\
\hline & 0 & 1 & 1 & 0 & 1 & 0 & 0 & 1 & 0 & 1 \\
\hline & 0 & 1 & 1 & 0 & 1 & 0 & 0 & 1 & 1 & 1 \\
\hline & 0 & 1 & 1 & 0 & 1 & 0 & 1 & 0 & 0 & 1 \\
\hline & 0 & 1 & 1 & 0 & 1 & 0 & 1 & 0 & 1 & 1 \\
\hline
\end{tabular}


Cont'd Table 5. Truth Tables

QCA Type Household Traits

Complete

\begin{tabular}{|c|c|c|c|c|c|c|}
\hline Rancher & Region & Education (female) & Water & Climate & Social & Financial \\
\hline J & $\mathrm{R}$ & $\mathrm{E}$ & W & $\mathrm{C}$ & S & $\mathrm{F}$ \\
\hline 0 & 1 & 1 & 0 & 1 & 0 & 1 \\
\hline 0 & 1 & 1 & 0 & 1 & 1 & 0 \\
\hline 0 & 1 & 1 & 0 & 1 & 1 & 0 \\
\hline 0 & 1 & 1 & 0 & 1 & 1 & 0 \\
\hline 0 & 1 & 1 & 0 & 1 & 1 & 1 \\
\hline 0 & 1 & 1 & 0 & 1 & 1 & 1 \\
\hline 0 & 1 & 1 & 1 & 1 & 0 & 0 \\
\hline 0 & 1 & 1 & 1 & 1 & 0 & 0 \\
\hline 0 & 1 & 1 & 1 & 1 & 1 & 1 \\
\hline 1 & 0 & 0 & 0 & 0 & 0 & 1 \\
\hline 1 & 0 & 0 & 1 & 1 & 1 & 0 \\
\hline 1 & 0 & 1 & 0 & 1 & 0 & 1 \\
\hline 1 & 0 & 1 & 0 & 1 & 0 & 1 \\
\hline 1 & 0 & 1 & 0 & 1 & 1 & 1 \\
\hline 1 & 0 & 1 & 1 & 0 & 0 & 1 \\
\hline 1 & 0 & 1 & 1 & 1 & 0 & 0 \\
\hline 1 & 0 & 1 & 1 & 1 & 0 & 1 \\
\hline 1 & 0 & 1 & 1 & 1 & 1 & 0 \\
\hline 1 & 0 & 1 & 1 & 1 & 1 & 1 \\
\hline 1 & 1 & 0 & 0 & 0 & 0 & 0 \\
\hline 1 & 1 & 0 & 0 & 0 & 1 & 1 \\
\hline 1 & 1 & 0 & 0 & 1 & 0 & 0 \\
\hline 1 & 1 & 0 & 0 & 1 & 0 & 0 \\
\hline 1 & 1 & 0 & 0 & 1 & 0 & 1 \\
\hline 1 & 1 & 0 & 0 & 1 & 0 & 1 \\
\hline 1 & 1 & 0 & 0 & 1 & 1 & 0 \\
\hline 1 & 1 & 0 & 0 & 1 & 1 & 1 \\
\hline 1 & 1 & 0 & 0 & 1 & 1 & 1 \\
\hline 1 & 1 & 0 & 1 & 1 & 1 & 1 \\
\hline 1 & 1 & 1 & 0 & 1 & 0 & 1 \\
\hline 1 & 1 & 1 & 0 & 1 & 0 & 1 \\
\hline 1 & 1 & 1 & 0 & 1 & 1 & 1 \\
\hline 1 & 1 & 1 & 0 & 1 & 1 & 1 \\
\hline 1 & 1 & 1 & 1 & 1 & 1 & 1 \\
\hline 0 & 0 & 0 & 0 & 0 & 0 & 1 \\
\hline 0 & 0 & 0 & 0 & 1 & 1 & 0 \\
\hline 0 & 0 & 0 & 0 & 1 & 1 & 1 \\
\hline 0 & 0 & 0 & 0 & 1 & 1 & 1 \\
\hline 0 & 0 & 0 & 1 & 1 & 0 & 1 \\
\hline 0 & 0 & 0 & 1 & 1 & 1 & 1 \\
\hline 0 & 0 & 1 & 0 & 0 & 1 & 0 \\
\hline 0 & 0 & 1 & 0 & 1 & 0 & 0 \\
\hline
\end{tabular}

Title Livestock Present

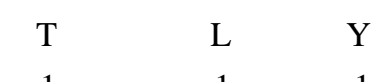

.

1
0
1
0


Cont'd Table 5. Truth Tables

QCA Type

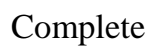

Household Traits

Ranche

\section{$\mathrm{J}$
0}

0

0

0

0

0

0

0

0

0

0

0

0

0

0

0

0

0

0

0

0

0

0

0

0

0

0

0

0

0

0

0

0

0

0

0

0

0

0

0

0

0

$\mathrm{R}$
0

0

0

0

0

0

0

0

1

1

1

1

1
1

1

1
1

1

1

1
1

Region Education (female)

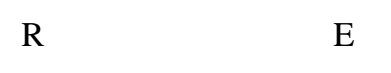

0
1

1
1

Water Climate

$\begin{array}{rrrr}\text { W } & \text { C } & \text { S } & \text { F } \\ 0 & 1 & 0 & 0\end{array}$

E
1
1
1

1

(1)

1

1

(1)

(1)


Cont'd Table 5. Truth Tables

QCA Type Household Traits

\begin{tabular}{|c|c|c|c|c|c|c|c|c|c|c|}
\hline \multirow{27}{*}{ Complete } & Rancher & Region & Education (female) & Water & Climate & Social & Financial & Title & Livestock & Present \\
\hline & J & $\mathrm{R}$ & $\mathrm{E}$ & W & $\mathrm{C}$ & $\mathrm{S}$ & $\mathrm{F}$ & $\mathrm{T}$ & $\mathrm{L}$ & $\mathrm{Y}$ \\
\hline & 1 & 0 & 0 & 0 & 0 & 0 & 1 & 1 & 1 & 0 \\
\hline & 1 & 0 & 0 & 1 & 1 & 1 & 0 & 1 & 1 & 0 \\
\hline & 1 & 0 & 1 & 0 & 1 & 0 & 1 & 0 & 1 & 0 \\
\hline & 1 & 0 & 1 & 0 & 1 & 0 & 1 & 1 & 1 & 0 \\
\hline & 1 & 0 & 1 & 0 & 1 & 1 & 1 & 1 & 1 & 0 \\
\hline & 1 & 0 & 1 & 1 & 0 & 0 & 1 & 0 & 1 & 0 \\
\hline & 1 & 0 & 1 & 1 & 1 & 0 & 0 & 1 & 1 & 0 \\
\hline & 1 & 0 & 1 & 1 & 1 & 0 & 1 & 1 & 1 & 0 \\
\hline & 1 & 0 & 1 & 1 & 1 & 1 & 0 & 0 & 1 & 0 \\
\hline & 1 & 0 & 1 & 1 & 1 & 1 & 1 & 1 & 1 & 0 \\
\hline & 1 & 1 & 0 & 0 & 0 & 0 & 0 & 0 & 1 & 0 \\
\hline & 1 & 1 & 0 & 0 & 0 & 1 & 1 & 1 & 1 & 0 \\
\hline & 1 & 1 & 0 & 0 & 1 & 0 & 0 & 0 & 1 & 0 \\
\hline & 1 & 1 & 0 & 0 & 1 & 0 & 0 & 1 & 1 & 0 \\
\hline & 1 & 1 & 0 & 0 & 1 & 0 & 1 & 0 & 1 & 0 \\
\hline & 1 & 1 & 0 & 0 & 1 & 0 & 1 & 1 & 1 & 0 \\
\hline & 1 & 1 & 0 & 0 & 1 & 1 & 0 & 0 & 1 & 0 \\
\hline & 1 & 1 & 0 & 0 & 1 & 1 & 1 & 0 & 1 & 0 \\
\hline & 1 & 1 & 0 & 0 & 1 & 1 & 1 & 1 & 1 & 0 \\
\hline & 1 & 1 & 0 & 1 & 1 & 1 & 1 & 1 & 1 & 0 \\
\hline & 1 & 1 & 1 & 0 & 1 & 0 & 1 & 0 & 1 & 0 \\
\hline & 1 & 1 & 1 & 0 & 1 & 0 & 1 & 1 & 1 & 0 \\
\hline & 1 & 1 & 1 & 0 & 1 & 1 & 1 & 0 & 1 & 0 \\
\hline & 1 & 1 & 1 & 0 & 1 & 1 & 1 & 1 & 1 & 0 \\
\hline & 1 & 1 & 1 & 1 & 1 & 1 & 1 & 1 & 1 & 0 \\
\hline
\end{tabular}


Cont'd Table 5. Truth Tables

QCA Type Household Traits

Rancher

Missing $=0$

\section{Region Education (female)}

$\mathrm{R}$

0

0

0

0

0

0

0

0

0

0

0

0

0

0

0

0

0

0$$
0
$$

0

0 
Cont'd Table 5. Truth Tables

QCA Type Household Traits

Rancher

Missing $=0$

\section{Region Education (female)}

\section{$\mathrm{R}$}

0

0

0
0

0

0

0

0

0

0

0

0

0

0

1$$
1
$$

1

1

1

1

$\begin{array}{ll}1 & 0 \\ 1 & 0\end{array}$

1

E
1

Water Climate

$\begin{array}{rr}\text { W } & \text { C } \\ 0 & 1 \\ 0 & 1\end{array}$


Cont'd Table 5. Truth Tables

QCA Type Household Traits

\begin{tabular}{|c|c|c|c|c|c|c|c|c|c|c|}
\hline & Rancher & Region & Education (female) & Water & Climate & Social & Financial & Title & Livestock & Present \\
\hline & $\mathbf{J}$ & $\mathrm{R}$ & $\mathrm{E}$ & W & $\mathrm{C}$ & $\mathrm{S}$ & $\mathrm{F}$ & $\mathrm{T}$ & $\mathrm{L}$ & $\mathrm{Y}$ \\
\hline & 0 & 0 & 0 & 0 & 1 & 0 & 0 & 1 & 0 & 0 \\
\hline \multirow[t]{42}{*}{ Missing $=0$} & 0 & 0 & 0 & 0 & 1 & 0 & 1 & 0 & 1 & 0 \\
\hline & 0 & 0 & 0 & 0 & 1 & 1 & 0 & 1 & 0 & 0 \\
\hline & 0 & 0 & 0 & 0 & 1 & 1 & 1 & 0 & 1 & 0 \\
\hline & 0 & 0 & 0 & 0 & 1 & 1 & 1 & 1 & 1 & 0 \\
\hline & 0 & 0 & 0 & 1 & 1 & 0 & 1 & 1 & 1 & 0 \\
\hline & 0 & 0 & 0 & 1 & 1 & 1 & 1 & 1 & 1 & 0 \\
\hline & 0 & 0 & 1 & 0 & 0 & 0 & 0 & 0 & 0 & 0 \\
\hline & 0 & 0 & 1 & 0 & 0 & 0 & 1 & 0 & 1 & 0 \\
\hline & 0 & 0 & 1 & 0 & 0 & 1 & 0 & 1 & 1 & 0 \\
\hline & 0 & 0 & 1 & 0 & 0 & 1 & 1 & 1 & 1 & 0 \\
\hline & 0 & 0 & 1 & 0 & 1 & 0 & 0 & 0 & 1 & 0 \\
\hline & 0 & 0 & 1 & 0 & 1 & 0 & 0 & 1 & 1 & 0 \\
\hline & 0 & 0 & 1 & 0 & 1 & 0 & 1 & 0 & 1 & 0 \\
\hline & 0 & 0 & 1 & 0 & 1 & 0 & 1 & 1 & 1 & 0 \\
\hline & 0 & 0 & 1 & 0 & 1 & 1 & 0 & 1 & 1 & 0 \\
\hline & 0 & 0 & 1 & 0 & 1 & 1 & 1 & 0 & 1 & 0 \\
\hline & 0 & 0 & 1 & 0 & 1 & 1 & 1 & 1 & 1 & 0 \\
\hline & 0 & 0 & 1 & 1 & 1 & 1 & 1 & 0 & 0 & 0 \\
\hline & 0 & 0 & 1 & 1 & 1 & 1 & 1 & 0 & 1 & 0 \\
\hline & 0 & 0 & 1 & 1 & 1 & 1 & 1 & 1 & 1 & 0 \\
\hline & 0 & 1 & 0 & 0 & 0 & 0 & 1 & 1 & 1 & 0 \\
\hline & 0 & 1 & 0 & 0 & 1 & 0 & 0 & 0 & 1 & 0 \\
\hline & 0 & 1 & 0 & 0 & 1 & 0 & 0 & 1 & 0 & 0 \\
\hline & 0 & 1 & 0 & 0 & 1 & 0 & 0 & 1 & 1 & 0 \\
\hline & 0 & 1 & 0 & 0 & 1 & 0 & 1 & 0 & 1 & 0 \\
\hline & 0 & 1 & 0 & 0 & 1 & 0 & 1 & 1 & 1 & 0 \\
\hline & 0 & 1 & 0 & 0 & 1 & 1 & 0 & 0 & 0 & 0 \\
\hline & 0 & 1 & 0 & 0 & 1 & 1 & 0 & 1 & 0 & 0 \\
\hline & 0 & 1 & 0 & 0 & 1 & 1 & 0 & 1 & 1 & 0 \\
\hline & 0 & 1 & 0 & 0 & 1 & 1 & 1 & 0 & 1 & 0 \\
\hline & 0 & 1 & 0 & 0 & 1 & 1 & 1 & 1 & 1 & 0 \\
\hline & 0 & 1 & 0 & 1 & 1 & 0 & 0 & 0 & 1 & 0 \\
\hline & 0 & 1 & 0 & 1 & 1 & 0 & 1 & 0 & 0 & 0 \\
\hline & 0 & 1 & 0 & 1 & 1 & 0 & 1 & 0 & 1 & 0 \\
\hline & 0 & 1 & 0 & 1 & 1 & 0 & 1 & 1 & 1 & 0 \\
\hline & 0 & 1 & 0 & 1 & 1 & 1 & 1 & 0 & 1 & 0 \\
\hline & 0 & 1 & 1 & 0 & 0 & 0 & 0 & 1 & 1 & 0 \\
\hline & 0 & 1 & 1 & 0 & 0 & 0 & 1 & 1 & 1 & 0 \\
\hline & 0 & 1 & 1 & 0 & 0 & 1 & 0 & 1 & 1 & 0 \\
\hline & 0 & 1 & 1 & 0 & 1 & 0 & 0 & 0 & 0 & 0 \\
\hline & 0 & 1 & 1 & 0 & 1 & 0 & 0 & 0 & 1 & 0 \\
\hline & & & & 37 & & & & & & \\
\hline
\end{tabular}


Cont'd Table 5. Truth Tables

\section{QCA Type Household Traits}

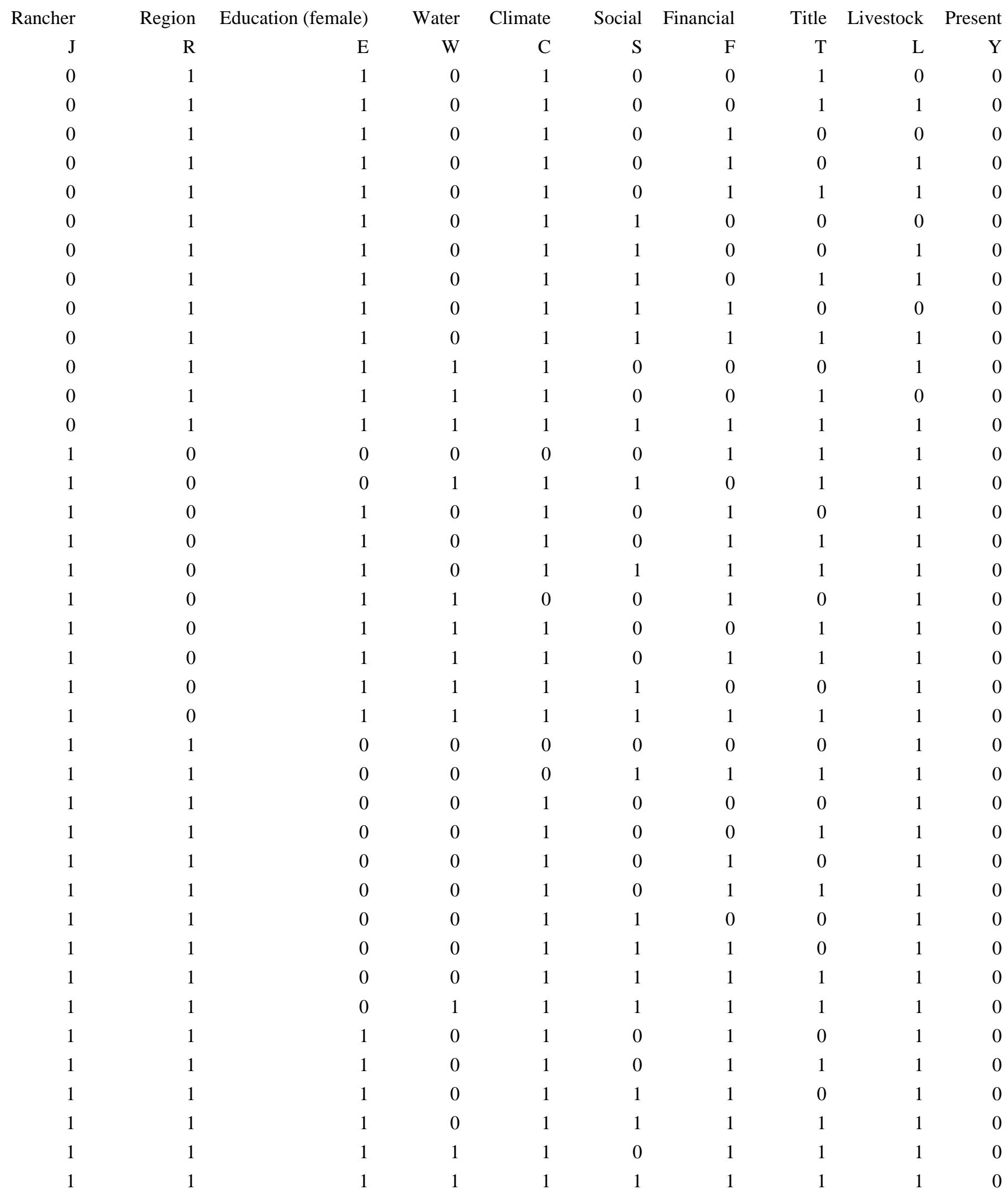


Cont'd Table 5. Truth Tables

QCA Type Household Traits

\begin{tabular}{|c|c|c|c|c|c|c|c|c|c|c|}
\hline & Rancher & Region & Education (female) & Water & Climate & Social & Fin & Title & Livestock & Present \\
\hline & $\mathbf{J}$ & $\mathrm{R}$ & $\mathrm{E}$ & $\mathrm{W}$ & $\mathrm{C}$ & $\mathrm{S}$ & $\mathrm{F}$ & $\mathrm{T}$ & $\mathrm{L}$ & $\mathrm{Y}$ \\
\hline \multirow[t]{42}{*}{ Missing $=1$} & 0 & 0 & 0 & 0 & 0 & 0 & 1 & 1 & 1 & 1 \\
\hline & 0 & 0 & 0 & 0 & 1 & 0 & 0 & 1 & 1 & 1 \\
\hline & 0 & 0 & 0 & 0 & 1 & 0 & 1 & 1 & 1 & 1 \\
\hline & 0 & 0 & 0 & 0 & 1 & 1 & 0 & 1 & 0 & 1 \\
\hline & 0 & 0 & 0 & 0 & 1 & 1 & 1 & 0 & 1 & 1 \\
\hline & 0 & 0 & 0 & 0 & 1 & 1 & 1 & 1 & 1 & 1 \\
\hline & 0 & 0 & 0 & 1 & 1 & 0 & 1 & 1 & 1 & 1 \\
\hline & 0 & 0 & 0 & 1 & 1 & 1 & 1 & 1 & 1 & 1 \\
\hline & 0 & 0 & 1 & 0 & 0 & 1 & 0 & 1 & 1 & 1 \\
\hline & 0 & 0 & 1 & 0 & 0 & 1 & 1 & 1 & 1 & 1 \\
\hline & 0 & 0 & 1 & 0 & 1 & 0 & 0 & 0 & 1 & 1 \\
\hline & 0 & 0 & 1 & 0 & 1 & 0 & 0 & 1 & 1 & 1 \\
\hline & 0 & 0 & 1 & 0 & 1 & 0 & 1 & 0 & 1 & 1 \\
\hline & 0 & 0 & 1 & 0 & 1 & 0 & 1 & 1 & 1 & 1 \\
\hline & 0 & 0 & 1 & 0 & 1 & 1 & 0 & 1 & 1 & 1 \\
\hline & 0 & 0 & 1 & 0 & 1 & 1 & 1 & 0 & 1 & 1 \\
\hline & 0 & 0 & 1 & 0 & 1 & 1 & 1 & 1 & 1 & 1 \\
\hline & 0 & 0 & 1 & 1 & 1 & 1 & 1 & 0 & 1 & 1 \\
\hline & 0 & 0 & 1 & 1 & 1 & 1 & 1 & 1 & 1 & 1 \\
\hline & 0 & 1 & 0 & 0 & 0 & 0 & 1 & 1 & 1 & 1 \\
\hline & 0 & 1 & 0 & 0 & 1 & 0 & 0 & 0 & 1 & 1 \\
\hline & 0 & 1 & 0 & 0 & 1 & 0 & 0 & 1 & 0 & 1 \\
\hline & 0 & 1 & 0 & 0 & 1 & 0 & 0 & 1 & 1 & 1 \\
\hline & 0 & 1 & 0 & 0 & 1 & 0 & 1 & 0 & 1 & 1 \\
\hline & 0 & 1 & 0 & 0 & 1 & 0 & 1 & 1 & 1 & 1 \\
\hline & 0 & 1 & 0 & 0 & 1 & 1 & 0 & 0 & 0 & 1 \\
\hline & 0 & 1 & 0 & 0 & 1 & 1 & 0 & 1 & 0 & 1 \\
\hline & 0 & 1 & 0 & 0 & 1 & 1 & 0 & 1 & 1 & 1 \\
\hline & 0 & 1 & 0 & 0 & 1 & 1 & 1 & 0 & 1 & 1 \\
\hline & 0 & 1 & 0 & 0 & 1 & 1 & 1 & 1 & 1 & 1 \\
\hline & 0 & 1 & 0 & 1 & 1 & 0 & 0 & 0 & 1 & 1 \\
\hline & 0 & 1 & 0 & 1 & 1 & 0 & 1 & 0 & 0 & 1 \\
\hline & 0 & 1 & 0 & 1 & 1 & 0 & 1 & 0 & 1 & 1 \\
\hline & 0 & 1 & 0 & 1 & 1 & 0 & 1 & 1 & 1 & 1 \\
\hline & 0 & 1 & 0 & 1 & 1 & 1 & 1 & 0 & 1 & 1 \\
\hline & 0 & 1 & 1 & 0 & 0 & 0 & 0 & 1 & 1 & 1 \\
\hline & 0 & 1 & 1 & 0 & 0 & 0 & 1 & 1 & 1 & 1 \\
\hline & 0 & 1 & 1 & 0 & 0 & 1 & 0 & 1 & 1 & 1 \\
\hline & 0 & 1 & 1 & 0 & 1 & 0 & 0 & 0 & 0 & 1 \\
\hline & 0 & 1 & 1 & 0 & 1 & 0 & 0 & 0 & 1 & 1 \\
\hline & 0 & 1 & 1 & 0 & 1 & 0 & 0 & 1 & 0 & 1 \\
\hline & 0 & 1 & 1 & 0 & 1 & 0 & 0 & 1 & 1 & 1 \\
\hline
\end{tabular}


Cont'd Table 5. Truth Tables

QCA Type

\begin{tabular}{|c|c|c|}
\hline & Rancher & Region \\
\hline & $\mathbf{J}$ & $\mathrm{R}$ \\
\hline Missing $=1$ & 0 & 1 \\
\hline & 0 & 1 \\
\hline & 0 & 1 \\
\hline & 0 & 1 \\
\hline & 0 & 1 \\
\hline & 0 & 1 \\
\hline & 0 & 1 \\
\hline & 0 & 1 \\
\hline & 0 & 1 \\
\hline & 0 & 1 \\
\hline & 1 & 0 \\
\hline & 1 & 0 \\
\hline & 1 & 0 \\
\hline & 1 & 0 \\
\hline & 1 & 0 \\
\hline & 1 & 0 \\
\hline & 1 & 0 \\
\hline & 1 & 0 \\
\hline & 1 & 0 \\
\hline & 1 & 0 \\
\hline & 1 & 1 \\
\hline & 1 & 1 \\
\hline & 1 & 1 \\
\hline & 1 & 1 \\
\hline & 1 & 1 \\
\hline & 1 & 1 \\
\hline & 1 & 1 \\
\hline & 1 & 1 \\
\hline & 1 & 1 \\
\hline & 1 & 1 \\
\hline & 1 & 1 \\
\hline & 1 & 1 \\
\hline & 1 & 1 \\
\hline & 1 & 1 \\
\hline & 1 & 1 \\
\hline & 0 & 0 \\
\hline & 0 & 0 \\
\hline & 0 & 0 \\
\hline & 0 & 0 \\
\hline & 0 & 0 \\
\hline & 0 & 0 \\
\hline
\end{tabular}

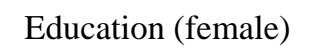

\section{(fenale)}

1

\section{E}

1

1

$$
1
$$$$
\text { (1) }
$$$$
\text { (1) }
$$ 
Cont'd Table 5. Truth Tables

QCA Type

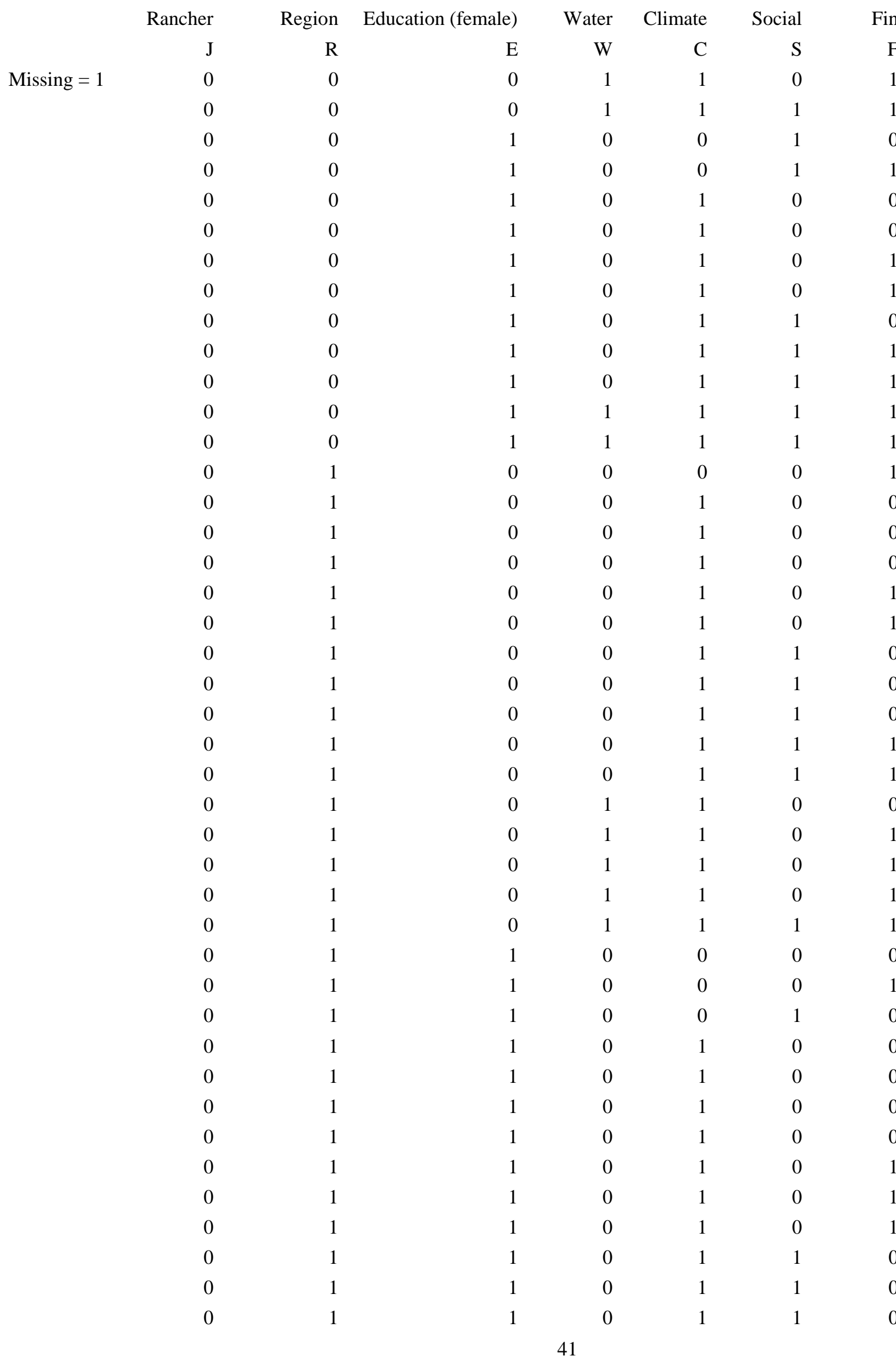


Cont'd Table 5. Truth Tables

QCA Type

Household Traits

\begin{tabular}{|c|c|c|c|c|c|c|c|c|c|}
\hline Rancher & Region & Education (female) & Water & Climate & Social & Fin & Title & Livestock & Present \\
\hline $\mathrm{J}$ & $\mathrm{R}$ & $\mathrm{E}$ & $\mathrm{W}$ & $\mathrm{C}$ & $\mathrm{S}$ & $\mathrm{F}$ & $\mathrm{T}$ & $\mathrm{L}$ & $\mathrm{Y}$ \\
\hline 0 & 1 & 1 & 0 & 1 & 1 & 1 & 1 & 1 & 0 \\
\hline 0 & 1 & 1 & 1 & 1 & 0 & 0 & 1 & 0 & 0 \\
\hline 0 & 1 & 1 & 1 & 1 & 1 & 1 & 1 & 1 & 0 \\
\hline 1 & 0 & 0 & 1 & 1 & 1 & 0 & 1 & 1 & 0 \\
\hline 1 & 0 & 1 & 0 & 1 & 0 & 1 & 0 & 1 & 0 \\
\hline 1 & 0 & 1 & 0 & 1 & 0 & 1 & 1 & 1 & 0 \\
\hline 1 & 0 & 1 & 0 & 1 & 1 & 1 & 1 & 1 & 0 \\
\hline 1 & 0 & 1 & 1 & 1 & 1 & 0 & 0 & 1 & 0 \\
\hline 1 & 0 & 1 & 1 & 1 & 1 & 1 & 1 & 1 & 0 \\
\hline 1 & 1 & 0 & 0 & 0 & 0 & 0 & 0 & 1 & 0 \\
\hline 1 & 1 & 0 & 0 & 0 & 1 & 1 & 1 & 1 & 0 \\
\hline 1 & 1 & 0 & 0 & 1 & 0 & 0 & 0 & 1 & 0 \\
\hline 1 & 1 & 0 & 0 & 1 & 0 & 0 & 1 & 1 & 0 \\
\hline 1 & 1 & 0 & 0 & 1 & 0 & 1 & 0 & 1 & 0 \\
\hline 1 & 1 & 0 & 0 & 1 & 0 & 1 & 1 & 1 & 0 \\
\hline 1 & 1 & 1 & 0 & 1 & 1 & 1 & 0 & 1 & 0 \\
\hline 1 & 1 & 1 & 0 & 1 & 1 & 1 & 1 & 1 & 0 \\
\hline 1 & 1 & 1 & 1 & 1 & 1 & 1 & 1 & 1 & 0 \\
\hline
\end{tabular}


Table 6. Facilitating and hindering traits for outcomes

\begin{tabular}{|c|c|c|c|c|}
\hline QCA TYPE & Adaptation & Trait & Positive & Negative \\
\hline complete & all & $\mathrm{J}$ & 0.41 & 0.00 \\
\hline complete & all & $\mathrm{R}$ & 0.41 & 1.00 \\
\hline complete & all & $\mathrm{E}$ & 0.41 & 0.50 \\
\hline complete & all & $\mathrm{W}$ & 0.36 & 0.00 \\
\hline complete & all & $\mathrm{C}$ & 0.68 & 1.00 \\
\hline complete & all & $\mathrm{S}$ & 0.50 & 0.00 \\
\hline complete & all & $\mathrm{F}$ & 0.50 & 0.00 \\
\hline complete & all & $\mathrm{T}$ & 0.45 & 0.00 \\
\hline complete & all & $\mathrm{L}$ & 0.82 & 0.50 \\
\hline complete & environmental migration & $\mathrm{J}$ & 0.67 & 0.32 \\
\hline complete & environmental migration & $\mathrm{R}$ & 0.33 & 0.45 \\
\hline complete & environmental migration & $\mathrm{E}$ & 0.33 & 0.45 \\
\hline complete & environmental migration & W & 0.67 & 0.23 \\
\hline complete & environmental migration & $\mathrm{C}$ & 0.67 & 0.86 \\
\hline complete & environmental migration & $\mathrm{S}$ & 0.67 & 0.27 \\
\hline complete & environmental migration & $\mathrm{F}$ & 0.33 & 0.50 \\
\hline complete & environmental migration & $\mathrm{T}$ & 1.00 & 0.36 \\
\hline complete & environmental migration & $\mathrm{L}$ & 1.00 & 0.82 \\
\hline complete & any household migration & $\mathrm{J}$ & 0.17 & 0.52 \\
\hline complete & any household migration & $\mathrm{R}$ & 0.17 & 0.43 \\
\hline complete & any household migration & $\mathrm{E}$ & 0.83 & 0.24 \\
\hline complete & any household migration & $\mathrm{W}$ & 0.17 & 0.24 \\
\hline complete & any household migration & $\mathrm{C}$ & 0.67 & 0.71 \\
\hline complete & any household migration & $\mathrm{S}$ & 0.33 & 0.38 \\
\hline complete & any household migration & $\mathrm{F}$ & 0.50 & 0.48 \\
\hline complete & any household migration & $\mathrm{T}$ & 0.50 & 0.43 \\
\hline complete & any household migration & $\mathrm{L}$ & 0.67 & 0.76 \\
\hline complete & farm & $\mathrm{J}$ & 0.55 & 0.22 \\
\hline complete & farm & $\mathrm{R}$ & 0.45 & 0.78 \\
\hline complete & farm & $\mathrm{E}$ & 0.25 & 0.33 \\
\hline complete & farm & $\mathrm{W}$ & 0.25 & 0.11 \\
\hline complete & farm & $\mathrm{C}$ & 0.75 & 1.00 \\
\hline complete & farm & $\mathrm{S}$ & 0.40 & 0.22 \\
\hline complete & farm & $\mathrm{F}$ & 0.50 & 0.33 \\
\hline complete & farm & $\mathrm{T}$ & 0.45 & 0.44 \\
\hline complete & farm & $\mathrm{L}$ & 0.80 & 0.56 \\
\hline complete & off-farm & $\mathrm{J}$ & 0.39 & 0.44 \\
\hline complete & off-farm & $\mathrm{R}$ & 0.33 & 0.78 \\
\hline complete & off-farm & $\mathrm{E}$ & 0.50 & 0.22 \\
\hline complete & off-farm & $\mathrm{W}$ & 0.33 & 0.22 \\
\hline complete & off-farm & $\mathrm{C}$ & 0.72 & 0.89 \\
\hline
\end{tabular}


Cont'd Table 6. Facilitating and hindering traits for outcomes

\begin{tabular}{|c|c|c|c|c|}
\hline complete & off-farm & $\mathrm{S}$ & 0.39 & 0.33 \\
\hline complete & off-farm & $\mathrm{F}$ & 0.50 & 0.56 \\
\hline complete & off-farm & $\mathrm{T}$ & 0.44 & 0.11 \\
\hline complete & off-farm & $\mathrm{L}$ & 0.83 & 0.78 \\
\hline $\operatorname{missing}=0$ & all & $\mathrm{J}$ & 0.38 & 0.00 \\
\hline missing $=0$ & all & $\mathrm{R}$ & 0.38 & 1.00 \\
\hline $\operatorname{missing}=0$ & all & $\mathrm{E}$ & 0.46 & 0.50 \\
\hline $\operatorname{missing}=0$ & all & $\mathrm{W}$ & 0.23 & 0.00 \\
\hline $\operatorname{missing}=0$ & all & $\mathrm{C}$ & 0.73 & 1.00 \\
\hline missing $=0$ & all & $\mathrm{S}$ & 0.31 & 0.00 \\
\hline $\operatorname{missing}=0$ & all & $\mathrm{F}$ & 0.54 & 0.00 \\
\hline $\operatorname{missing}=0$ & all & $\mathrm{T}$ & 0.38 & 0.00 \\
\hline $\operatorname{missing}=0$ & all & $\mathrm{L}$ & 0.81 & 0.50 \\
\hline $\operatorname{missing}=0$ & environmental migration & $\mathrm{J}$ & 0.75 & 0.32 \\
\hline $\operatorname{missing}=0$ & environmental migration & $\mathrm{R}$ & 0.25 & 0.40 \\
\hline missing $=0$ & environmental migration & $\mathrm{E}$ & 0.50 & 0.60 \\
\hline $\operatorname{missing}=0$ & environmental migration & $\mathrm{W}$ & 0.50 & 0.20 \\
\hline $\operatorname{missing}=0$ & environmental migration & $\mathrm{C}$ & 1.00 & 0.68 \\
\hline $\operatorname{missing}=0$ & environmental migration & $\mathrm{S}$ & 0.25 & 0.24 \\
\hline $\operatorname{missing}=0$ & environmental migration & $\mathrm{F}$ & 0.25 & 0.52 \\
\hline $\operatorname{missing}=0$ & environmental migration & $\mathrm{T}$ & 1.00 & 0.32 \\
\hline $\operatorname{missing}=0$ & environmental migration & $\mathrm{L}$ & 1.00 & 0.76 \\
\hline $\operatorname{missing}=0$ & any household migration & $\mathrm{J}$ & 0.46 & 0.43 \\
\hline $\operatorname{missing}=0$ & any household migration & $\mathrm{R}$ & 0.08 & 0.48 \\
\hline $\operatorname{missing}=0$ & any household migration & $\mathrm{E}$ & 0.77 & 0.38 \\
\hline $\operatorname{missing}=0$ & any household migration & $\mathrm{W}$ & 0.38 & 0.19 \\
\hline $\operatorname{missing}=0$ & any household migration & $\mathrm{C}$ & 0.69 & 0.71 \\
\hline $\operatorname{missing}=0$ & any household migration & $\mathrm{S}$ & 0.38 & 0.29 \\
\hline missing $=0$ & any household migration & $\mathrm{F}$ & 0.46 & 0.52 \\
\hline missing $=0$ & any household migration & $\mathrm{T}$ & 0.54 & 0.38 \\
\hline missing $=0$ & any household migration & $\mathrm{L}$ & 0.62 & 0.81 \\
\hline missing $=0$ & farm & $\mathrm{J}$ & 0.42 & 0.25 \\
\hline $\operatorname{missing}=0$ & farm & $\mathrm{R}$ & 0.21 & 0.88 \\
\hline missing $=0$ & farm & $\mathrm{E}$ & 0.58 & 0.25 \\
\hline missing $=0$ & farm & $\mathrm{W}$ & 0.26 & 0.13 \\
\hline $\operatorname{missing}=0$ & farm & $\mathrm{C}$ & 0.63 & 1.00 \\
\hline $\operatorname{missing}=0$ & farm & $\mathrm{S}$ & 0.37 & 0.13 \\
\hline $\operatorname{missing}=0$ & farm & $\mathrm{F}$ & 0.58 & 0.38 \\
\hline missing $=0$ & farm & $\mathrm{T}$ & 0.37 & 0.38 \\
\hline $\operatorname{missing}=0$ & farm & $\mathrm{L}$ & 0.89 & 0.50 \\
\hline $\operatorname{missing}=0$ & off-farm & $\mathrm{J}$ & 0.36 & 0.43 \\
\hline
\end{tabular}


Cont'd Table 6. Facilitating and hindering traits for outcomes

\begin{tabular}{|c|c|c|c|c|}
\hline missing $=0$ & off-farm & $\mathrm{R}$ & 0.32 & 0.71 \\
\hline missing $=0$ & off-farm & $\mathrm{E}$ & 0.50 & 0.43 \\
\hline missing $=0$ & off-farm & $\mathrm{W}$ & 0.27 & 0.29 \\
\hline missing $=0$ & off-farm & $\mathrm{C}$ & 0.77 & 0.86 \\
\hline missing $=0$ & off-farm & $\mathrm{S}$ & 0.27 & 0.14 \\
\hline missing $=0$ & off-farm & $\mathrm{F}$ & 0.55 & 0.43 \\
\hline missing $=0$ & off-farm & $\mathrm{T}$ & 0.41 & 0.29 \\
\hline $\operatorname{missing}=0$ & off-farm & $\mathrm{L}$ & 0.82 & 0.57 \\
\hline missing $=1$ & all & $\mathrm{J}$ & 0.39 & 0.00 \\
\hline $\operatorname{missing}=1$ & all & $\mathrm{R}$ & 0.39 & 1.00 \\
\hline $\operatorname{missing}=1$ & all & $\mathrm{E}$ & 0.39 & 0.50 \\
\hline $\operatorname{missing}=1$ & all & $\mathrm{W}$ & 0.22 & 0.00 \\
\hline $\operatorname{missing}=1$ & all & $\mathrm{C}$ & 0.78 & 1.00 \\
\hline $\operatorname{missing}=1$ & all & $\mathrm{S}$ & 0.39 & 0.00 \\
\hline $\operatorname{missing}=1$ & all & $\mathrm{F}$ & 0.52 & 0.00 \\
\hline $\operatorname{missing}=1$ & all & $\mathrm{T}$ & 0.48 & 0.00 \\
\hline $\operatorname{missing}=1$ & all & $\mathrm{L}$ & 0.87 & 0.50 \\
\hline missing $=1$ & environmental migration & $\mathrm{J}$ & 1.00 & 0.30 \\
\hline $\operatorname{missing}=1$ & environmental migration & $\mathrm{R}$ & 0.33 & 0.43 \\
\hline missing $=1$ & environmental migration & $\mathrm{E}$ & 0.33 & 0.43 \\
\hline missing $=1$ & environmental migration & $\mathrm{W}$ & 0.67 & 0.17 \\
\hline $\operatorname{missing}=1$ & environmental migration & $\mathrm{C}$ & 0.67 & 0.83 \\
\hline $\operatorname{missing}=1$ & environmental migration & $\mathrm{S}$ & 0.67 & 0.30 \\
\hline $\operatorname{missing}=1$ & environmental migration & $\mathrm{F}$ & 0.33 & 0.48 \\
\hline $\operatorname{missing}=1$ & environmental migration & $\mathrm{T}$ & 1.00 & 0.39 \\
\hline $\operatorname{missing}=1$ & environmental migration & $\mathrm{L}$ & 1.00 & 0.83 \\
\hline missing $=1$ & any household migration & $\mathrm{J}$ & 0.20 & 0.41 \\
\hline $\operatorname{missing}=1$ & any household migration & $\mathrm{R}$ & 0.20 & 0.45 \\
\hline missing $=1$ & any household migration & $\mathrm{E}$ & 0.80 & 0.32 \\
\hline missing $=1$ & any household migration & $\mathrm{W}$ & 0.20 & 0.18 \\
\hline $\operatorname{missing}=1$ & any household migration & $\mathrm{C}$ & 0.60 & 0.77 \\
\hline missing $=1$ & any household migration & $\mathrm{S}$ & 0.40 & 0.36 \\
\hline $\operatorname{missing}=1$ & any household migration & $\mathrm{F}$ & 0.40 & 0.50 \\
\hline $\operatorname{missing}=1$ & any household migration & $\mathrm{T}$ & 0.60 & 0.45 \\
\hline missing $=1$ & any household migration & $\mathrm{L}$ & 0.80 & 0.82 \\
\hline $\operatorname{missing}=1$ & farm & $\mathrm{J}$ & 0.41 & 0.25 \\
\hline missing $=1$ & farm & $\mathrm{R}$ & 0.24 & 0.88 \\
\hline $\operatorname{missing}=1$ & farm & $\mathrm{E}$ & 0.47 & 0.25 \\
\hline $\operatorname{missing}=1$ & farm & W & 0.24 & 0.13 \\
\hline $\operatorname{missing}=1$ & farm & $\mathrm{C}$ & 0.71 & 1.00 \\
\hline
\end{tabular}


Cont'd Table 6. Facilitating and hindering traits for outcomes

$\begin{array}{ll}\text { missing }=1 & \text { farm } \\ \text { missing }=1 & \text { farm } \\ \text { missing }=1 & \text { farm } \\ \text { missing }=1 & \text { farm } \\ \text { missing }=1 & \text { off-farm } \\ \text { missing }=1 & \text { off-farm } \\ \text { missing }=1 & \text { off-farm } \\ \text { missing }=1 & \text { off-farm } \\ \text { missing }=1 & \text { off-farm } \\ \text { missing }=1 & \text { off-farm } \\ \text { missing }=1 & \text { off-farm } \\ \text { missing }=1 & \text { off-farm } \\ \text { missing }=1 & \text { off-farm }\end{array}$

$0.47 \quad 0.38$

$0.47 \quad 0.25$

$0.47 \quad 0.38$

$1.00 \quad 0.50$

$0.37 \quad 0.38$

$0.32 \quad 0.75$

E

$0.47 \quad 0.25$

W

0.26

0.25

0.74

1.00

0.37

0.25

0.42

0.63

$\mathrm{T}$

0.53

0.25

L

0.84

0.75 
Figure 1. Percentage of presence and absence cases of household traits by the types of adaptation strategies we measured (Complete cases). Colors indicate trait score with warmer colors (reds) representing stronger association and cooler colors (blues) representing weaker association. Data should be read across rows, for example, the top row represents region to other household traits.

Abbreviations listed in Table 1
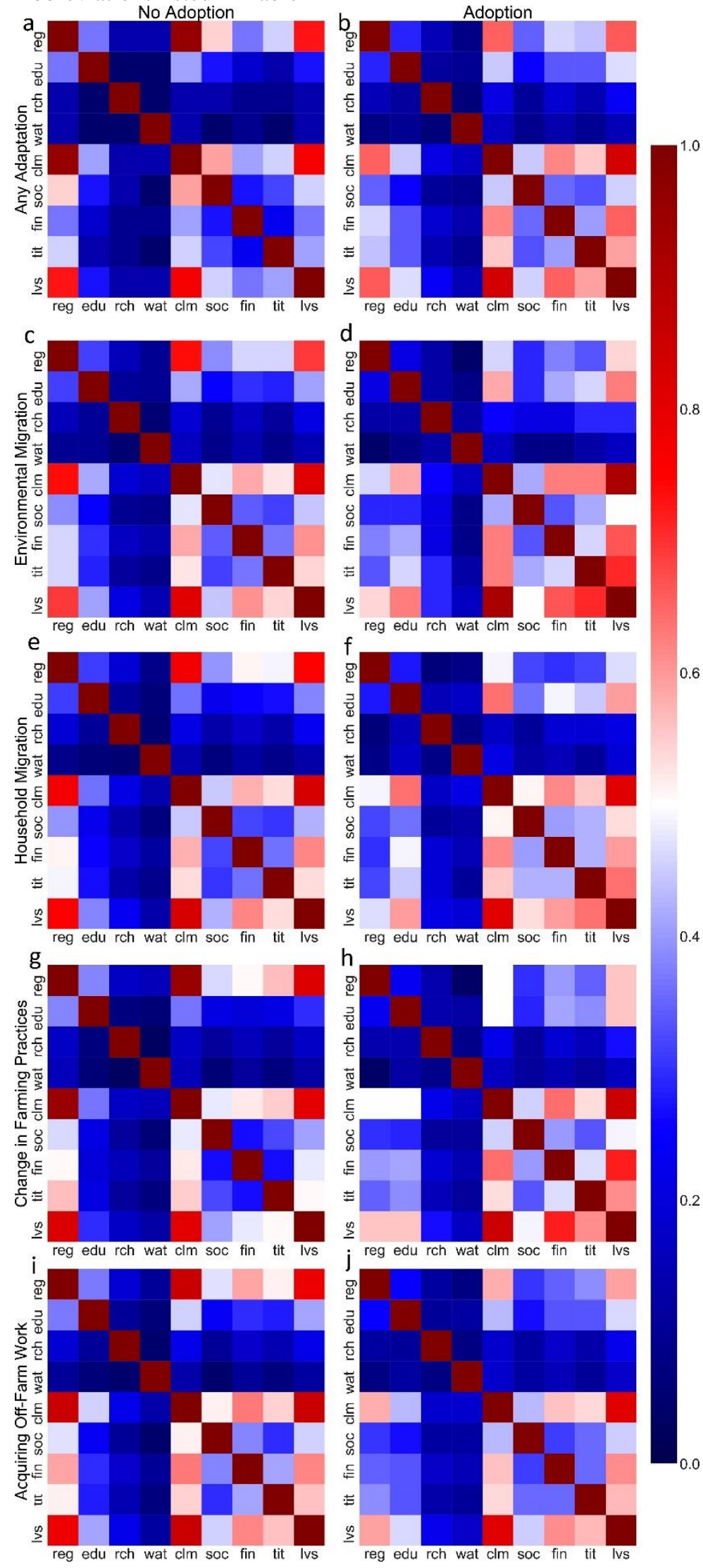
Figure 2. Percentage of presence and absence cases of household traits by the types of adaptation strategies we measured (Missing=0 cases).
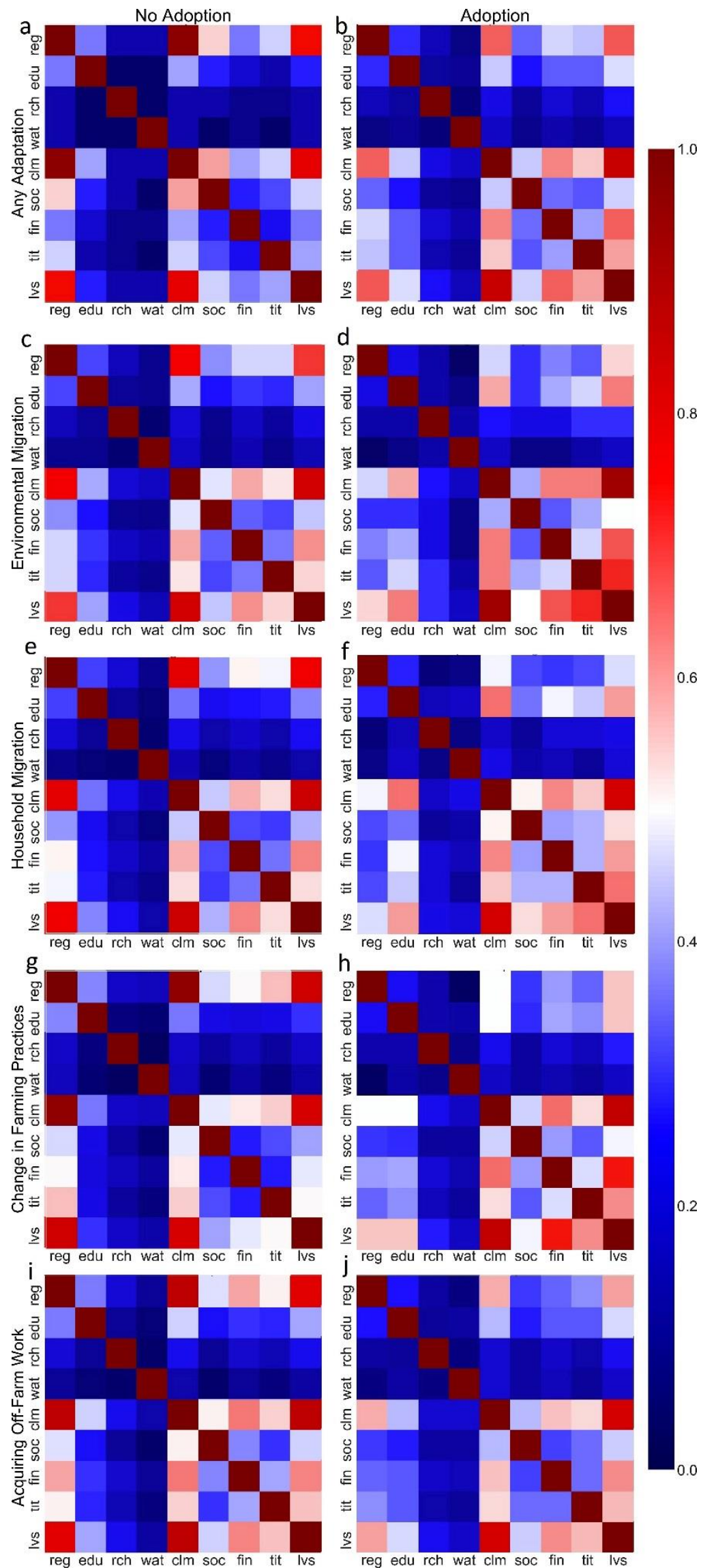
Figure 3. Percentage of presence and absence cases of household traits by the types of adaptation strategies we measured (Missing=1 cases).
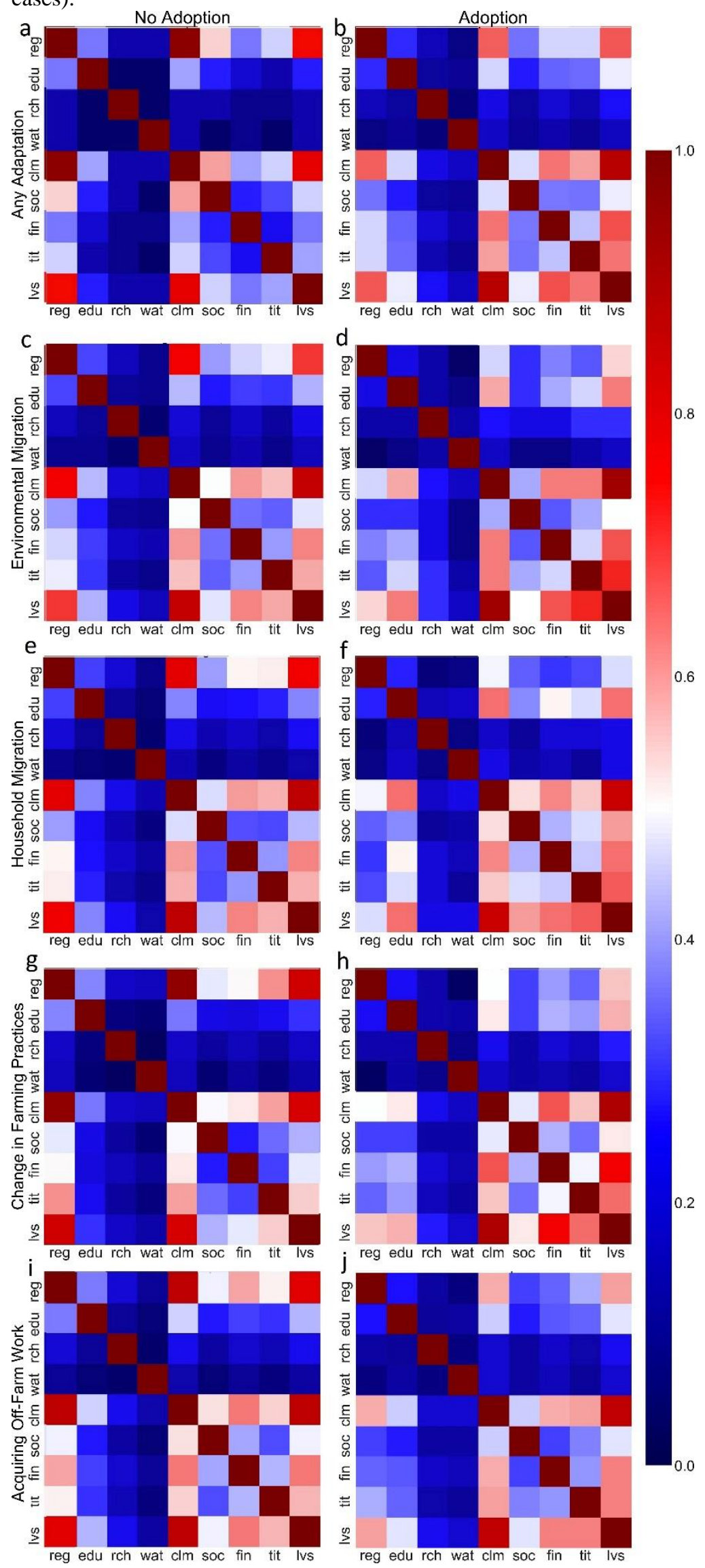
References

Baggio J, Barnett A, Perez-Ibarra I, Brady U, Ratajczyk E, Rollins N, Rubiños C, Shin H, Yu D, Aggarwal R, \& Anderies J (2016) Explaining success and failure in the commons: the configural nature of Ostrom's institutional design principles. International Journal of the Commons, 10(2), pp.417-439. doi:10.18352/ijc.634

Kusek JZ, Rist RC (2004) Ten steps to a results-based monitoring and evaluation system: a handbook for development practitioners. World Bank Publications

Ragin C (1987) The comparative method: Moving beyond qualitative and quantitative methods Berkeley: University of California

Ragin C (2006) Set relations in social research: Evaluating their consistency and coverage Political Analysis 14:291-310 doi:10.1093/pan/mpj019

Schneider, CQ, \& Wagemann, C (2010) Standards of good practice in qualitative comparative analysis (QCA) and fuzzy-sets. Comp Sociol 9(3):397-418. doi: 10.1163/156913210X12493538729793 